\title{
A REVIEW OF AFROTROPICAL
}

\section{TANYTARSUS VAN DER WULP}

\author{
(DIPTERA: CHIRONOMIDAE)
}

\begin{abstract}
Ekrem, T., 2001. A review of Afrotropical Tanytarsus van der Wulp (Diptera: Chironomidae). - Tijdschrift voor Entomologie 144: 5-40, figs. 1-106, tables 1-10. [ISSN 0040-7496]. Published 1 June 2001.

Tanytarsus ankasaensis sp. n., T. aterrimus Freeman, T. congus Lehmann, T. elisabethae sp. n., T. flexistilus Freeman, T. formosanus Kieffer, T. harei sp. n., T. luctuosus Freeman, T. mcmillani Freeman, T. spadiceonotatus Freeman, T. trifidus Freeman and T. zariae Freeman are described, all as male imago. Pupae and larvae of T. elisabethae, T. flexistilus, T. spadiceonotatus and T. trifidus are described for the first time. Pupae of T. formosanus and T. luctuosus are also described and figured. Keys to males, pupae and larvae of recognized Afrotropical Tanytarsus species, and an annotated checklist of the Afrotropical Tanytarsus species, as well as a list of the Ghanaian species with distributional records are given. T. formosae Kieffer, 1923a, T. horni Goetghebuer, T. aculeus Chaudhuri et al., 1988 and T. fuscimarginalis Chaudhuri et al., 1984 are claimed to be new junior synonyms of T. formosanus. T. atroxitarsus Chaudhuri \& Datta, 1992 is claimed to be a new junior synonym of T. mcmillani Freeman. Rheotanytarsus formosae Kieffer, 1921 recently transferred to Tanytarsus, is found to be a senior secondary homonym of T. formosae Kieffer, 1923a. Lectotypes and paralectotypes are designated for T. formosanus Kieffer and for T. formosae (Kieffer, 1921).

T. Ekrem, Museum of Zoology, University of Bergen, Muséplass 3, N-5019 Bergen, Norway. Keywords. - Africa; Chironomidae; Tanytarsus; new species; descriptions; check lists; keys; synonyms.
\end{abstract}

Although chironomid research in Africa never has reached the same intensity as in the Holarctic region, quite a few papers have been produced. Freeman $(1955,1956,1957 \mathrm{a}, 1957 \mathrm{~b}, 1958)$ treated close to 600 African species including synonyms and his works are the most comprehensive on African Chironomidae to date. It is nevertheless evident, that only a small portion of the African chironomid fauna is known. Many undescribed species, including seven of Tanytarsus van der Wulp, 1874 (Ekrem 1999, this work) were discovered in a few weeks of field work in Ghana (1993-4). Unfortunately, many of the old descriptions of Afrotropical Tanytarsus species are of poor quality and some of the types are apparently lost. This has possibly resulted in some misidentifications through the years, and the need for redescriptions and updated keys for African Tanytarsus is evident. Tanytarsus is one of the most species-rich genera of the family Chironomidae, with at least 85 described species from the Holarctic region (Cranston et al. 1989). In the Catalogue of the Diptera of the Afrotropical region, Freeman \& Cranston (1980) list 24 species of Tanytarsus. Six of these, however, are listed by Freeman (1958) as unrecognised species de- scribed by Kieffer, one species belongs to the genus Rheotanytarsus (Kyerematen \& Sæther 2000), and two species, $T$. nigricornis and T. subreflexens, were placed in the genus Virgatanytarsus by Pinder (1982). Stur \& Ekrem (2000) give a review of other Afrotropical species previously described in Tanytarsus. With the addition of the three new species described below, 26 Tanytarsus species are now recognized from the Afrotropical region. This paper was initiated as part of a world revision of the Tanytarsus eminulus, gregarius, lugens and mendax species groups (Reiss \& Fittkau 1971). Species in these groups have, in addition to other characters, spines between the anal point crests of the male hypopygium. For that reason, only Afrotropical species possessing such spines are redescribed here. However, all recognized species are included in the key to Afrotropical Tanytarsus males.

\section{METHODS AND MORPHOLOGY}

The terminology and abbreviations follows Sæther (1980), with the additions and corrections given by Sæther (1990). The term 'shoulders' is used for the posteriomarginal lobes of the male anal tergite and the 
term 'taeniae' (Langton 1994) is used for the filamentous setae (LS) of the pupal abdomen. The material that needed to be prepared for light microscopy is mounted or remounted in either Canada balsam or Euparal according to the procedures described by $S x-$ ther (1969). Measurements are taken according to Schlee (1966) with the additions given by Ekrem (1999). The shape of the median volsella lamellae is often difficult to see and squeezing or dissection of the hypopygium is often necessary to examine this character properly.

The following abbreviations are used: Deutsches Entomologisches Institut, Eberswalde, Germany (DEI), INRS-Eau, University of Quebec, Canada (UQC), Insect collections, Department of Zoology, University of Burdwan, India (UBI), The International Commission of Zoological Nomenclature (ICZN), Museum National d' Histoire Naturelle, Paris, France (MNHN), Museum of Zoology, University of Bergen, Norway (ZMBN), The Natural History Museum, London, UK (BMNH), Naturhistorisches Museum Wien, Vienna, Austria (NMW), Pupal exuviae (Pex) and the Zoologische Staatssammlung München, Munich, Germany (ZSM).

\section{Tanytarsus ankasaensis sp. $\mathrm{n}$.}

Type material. Holotype ô Ghana, Western Region, Ankasa Game Production Reserve, 711.12.1993, leg. NUFU-project (ZMBN Type No. 353). Paratype $10^{\hat{\sigma}}$ (ZMBN) Ghana, Great Accra Region, Stream by Institute of Aquatic Biology, Malaise trap, 19-23.X.1992, leg. NUFU-project.

\section{Etymology}

Tanytarsus ankasaensis is named after the type locality, the Ankasa Game Production Reserve.

\section{Diagnosis}

The new species differs from other Tanytarsus species by the following combination of characters: Small size, wing length c. $1 \mathrm{~mm} ; \mathrm{LR}_{1}>3.4 ; \mathrm{AR}<1$; male anal tergite with median setae; strong, trifid spines between well developed anal crests; small microtrichia-free area around anal point base; superior volsella with dorsolateral microtrichia; 3 median, 2 dorsal and 2 lateral setae; digitus slender, not reaching beyond median margin of superior volsella; gonostylus narrow with parallel sides.

\section{Description}

Male imago $(\mathrm{n}=2)$. - Total length $1.92-2.08 \mathrm{~mm}$. Wing length 1.11-1.14 mm. Total length/wing length 1.68-1.87. Coloration. Cleared specimens with head light brown, darker brown eyes; thorax with brown patches dorsally and laterally on scutum, scutellum, halteres and postnotum; legs light brownish; abdomen light yellowish.

Head. - Antenna normally developed, AR 0.81-0.92. Thirteenth flagellomere 365-374 $\mu \mathrm{m}$ long. Longest antennal seta c. $430 \mu \mathrm{m}$ long. Distance between eyes 129$162 \mu \mathrm{m}$. Frontal tubercles small, c. $10 \mu \mathrm{m}$ long. Temporal bristles $8-10 ; 2-3$ inner verticals, 3 outer verticals, 3-4 postorbitals. Clypeus triangular, 58-65 $\mu \mathrm{m}$ long with 12-15 setae. Tentorium 103-104 $\mu \mathrm{m}$ long, 23-24 $\mu \mathrm{m}$ wide at sieve pore. Stipes 112-113 $\mu \mathrm{m}$ long, 9-14 $\mu \mathrm{m}$ wide. Width of cibarial pump 39-40 $\mu \mathrm{m}$. Lengths of palp segments (in $\mu \mathrm{m}$ ) (palpomere 5 lost in both specimens): 23-25, 26-29, 101-107, 103-108.

Thorax. - Dorsocentrals 5-8, acrostichals 8-11, prealars 1, scutellars 2-4. 5-6 setae on halteres.

Wing. - VR 1.23-1.33. Sc bare, R with 14-25 setae, $\mathrm{R}_{1}$ with 15-16, $\mathrm{R}_{4+5}$ with $24, \mathrm{M}_{1+2}$ with $32-42, \mathrm{M}_{3+4}$ with 23-25, Cu with 4-17, $\mathrm{Cu}_{1}$ with 13-17, PCu with 0-19 and An with 14-23 setae. Cells: $m$ with 0-5 setae, $\mathrm{r}_{4+5}$ with 79-100, $\mathrm{m}_{1+2}$ with 83-140 including on false vein, $m_{3+4}$ with $23-66$, cu with $0-18$ and an with $0-13$ setae.

Legs. - Spur on front tibia 29-30 $\mu \mathrm{m}$ long including scale. Spurs of middle tibia $25-30 \mu \mathrm{m}$ long including $14 \mu \mathrm{m}$ long comb and $20 \mu \mathrm{m}$ long including $14 \mu \mathrm{m}$ long comb; of hind tibia $32 \mu \mathrm{m}$ long including 13-18 $\mu \mathrm{m}$ long comb and $29 \mu \mathrm{m}$ long including $13-$ $16 \mu \mathrm{m}$ long comb. Lengths and proportions of legs see table 1 .

Hypopygium (fig. 1). - Tergite IX 86-98 $\mu \mathrm{m}$ long with 2-6 median and 12-14 apical setae; apical margin with shoulders; 2 lateral teeth barely recognisable; microtrichia absent in a small area around base of anal point. Anal point 43-45 $\mu \mathrm{m}$ long, $12-20 \mu \mathrm{m}$ wide at base and 4-6 $\mu \mathrm{m}$ wide at apex. Anal point with 4 strong trifid spines between well developed anal crests. Anal tergite bands curved caudally, almost reaching anal

Table 1. T. ankasaensis. Lengths (in $\mu \mathrm{m})$ and proportions of legs $(\mathrm{n}=1-2)$.

\begin{tabular}{|c|c|c|c|c|c|c|c|c|c|c|c|}
\hline & $\mathrm{fe}$ & $\mathrm{ti}$ & $\mathrm{ta}_{1}$ & $\mathrm{ta}_{2}$ & $\mathrm{ta}_{3}$ & $\mathrm{ta}_{4}$ & $\mathrm{ta}_{5}$ & LR & BV & SV & $\mathrm{BR}$ \\
\hline $\mathrm{p}_{1}$ & $578-598$ & $252-258$ & 891 & 388 & 323 & 258 & 113 & 3.45 & 1.60 & 0.94 & 4.4 \\
\hline $\mathrm{p}_{2}$ & $526-587$ & $439-443$ & 274-299 & $116-126$ & $68-94$ & $40-42$ & $26-29$ & $0.62-0.68$ & $4.60-4.94$ & $3.43-3.52$ & $4.2-5.8$ \\
\hline $\begin{array}{l}\mathrm{P}_{2} \\
\mathrm{p}_{3}\end{array}$ & $522-543$ & $576-578$ & $371-407$ & $226-238$ & $216-230$ & $116-133$ & $58-61$ & $0.64-0.71$ & $2.27-2.42$ & $2.70-3.02$ & $3.5-4.8$ \\
\hline
\end{tabular}


point. Transverse sternapodeme 43-45 $\mu \mathrm{m}$ long, phallapodeme 86-91 $\mu \mathrm{m}$ long. Gonocoxite 82-98 $\mu \mathrm{m}$ long, gonostylus 66-77 $\mu \mathrm{m}$ long. Superior volsella (fig. 2) tapered towards a median elongated apex; bearing 2 setae dorsally; 2 setae laterally and 3 setae medially with the apical 2 much stronger than the basal one; dorsolateral microtrichia present. Digitus medium long and slender not reaching beyond median margin of superior volsella. Median volsella short $14-23 \mu \mathrm{m}$ long with $\mathrm{c}$. $10,20-21 \mu \mathrm{m}$ long, subulate lamellae. Inferior volsella relatively straight, club shaped, $59 \mu \mathrm{m}$ long, with c. 13 apical setae. HR 1.25-1.26, HV 2.49-3.15.

\section{Remarks}

Tanytarsus ankasaensis keys to the $T$. mendax species group (Cranston et al. 1989), and fits the group diagnosis when ignoring the low antennal ratio. It differs from all other species in this group by having a $\mathrm{LR}_{1}>3.4$, a well developed digitus and dorsolateral microtrichia on superior volsella.

The Ankasa Game Production Reserve $\left(5^{\circ} 17^{\prime} \mathrm{N}\right.$, $\left.2^{\circ} 35^{\prime} \mathrm{W}\right)$, is situated in the south-west part of Ghana close to the Côte d'Ivoire border. The vegetation consists of wet, tropical rainforest, annual rainfall is $1750-2000 \mathrm{~mm}$, and the area is rich in both fast and slow flowing rivers and streams. The height of the forest canopy rarely exceeds 40 metres and has a high diversity of species (Hall \& Swaine 1981).

The Institute of Aquatic Biology is located in the Great Accra region. A small slow flowing stream runs through a relatively dry area nearby. The Malaise trap was put up by the stream under the trees along the river bed.

\section{Tanytarsus aterrimus Freeman}

Tanytarsus aterrimus Freeman, 1954: 179, 1958: 338. Holo-

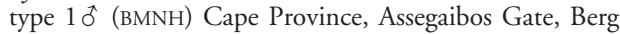
River, 14.VIII.1953, paratypes: $2 \hat{\delta}$ and 19 as holotype, 1 Cape Province, Tulbargh Barrage, 12.XI.1953, leg K. M. F. Scott. [examined].

\section{Diagnosis}

The species differs from other Tanytarsus species by the following combination of characters: hypopy- gium with 2 median setae on anal tergite; anal tergite bands of Y-type; anal point long and slender with spines between well developed anal crests; superior volsella well developed, roughly square, without microtrichia; digitus large, extending beyond median margin of superior volsella, one seta at base; median volsella with 2-3 pectinate and several setiform lamellae. Antennal ratio 0.8-1.0, $\mathrm{LR}_{1}$ 2.5-2.7. Frontal tubercles well developed.

\section{Description}

Male imago $(\mathrm{n}=2-3)$. - Total length 3.4-3.6 mm. Wing length $2.0-2.1 \mathrm{~mm}$. Total length/wing length 1.7. Coloration. Cleared specimens with head light brown, dark brown pedicel, apodemes and eyes; thorax with dark brown patches anteriorly and laterally on scutum, on postnotum and on preepisternum; antepronotum, scutellum and halteres somewhat lighter; legs mostly light brown, but darker femur and tibia of mid and hind legs; all tergites brown.

Head. - Antenna normally developed, AR 0.89-0.99. Thirteenth flagellomere 468-481 $\mu \mathrm{m}$ long. Longest antennal seta c. $550 \mu \mathrm{m}$ long. Distance between eyes 164 $\mu \mathrm{m}$. Frontal tubercles well developed, c. $16 \mu \mathrm{m}$ long. Temporal bristles 12-14; including 3-5 inner verticals, 4-6 outer verticals and 4-5 postorbitals. Clypeus semicircular, 64-71 $\mu \mathrm{m}$ long with 10-15 setae. Tentorium 152-161 $\mu \mathrm{m}$ long, 29-42 $\mu \mathrm{m}$ wide at sieve pore. Stipes 168- $194 \mu \mathrm{m}$ long, $39 \mu \mathrm{m}$ wide. Cibarial pump 64-77 $\mu \mathrm{m}$ wide. Lengths of palp segments (in $\mu \mathrm{m}$ ): $26-42$, 36-42, 116-129, 113-161, 161.

Thorax. - Dorsocentrals 6-10, acrostichals 7-8, prealars 1 , scutellars 6 . Halteres with 7 setae.

Wing. - VR 1.15-1.21. Sc bare, $R$ with 26-30 setae, $\mathrm{R}_{1}$ with 17-23, $\mathrm{R}_{4+5}$ with 24-29 $\mathrm{M}_{1+2}$ with 64-75, $\mathrm{M}_{3+4}$ with 35-38, Cu with 9-12, $\mathrm{Cu}_{1}$ with 23-26, PCu with 13-19 and An with 27-37 setae. Cell $m$ with 6 setae, $\mathrm{r}_{4+5}$ and $\mathrm{m}_{1+2}$ with c. 170 including on false vein, $\mathrm{m}_{3+4}$ with c. 80, cu and an combined with 23-70.

Legs. - Spur on front tibia c. $36 \mu \mathrm{m}$ long including scale. Spurs of middle tibia 36-42 $\mu \mathrm{m}$ long including 13-19 $\mu \mathrm{m}$ long comb and 26-29 $\mu \mathrm{m}$ long including $13-$ $19 \mu \mathrm{m}$ long comb; of hind tibia $45-48 \mu \mathrm{m}$ long including 19-26 $\mu \mathrm{m}$ long comb and 23-39 $\mu \mathrm{m}$ long including 16-23 $\mu \mathrm{m}$ long comb. Middle tibiae with 8 sensilla chaeticae. Lengths and proportions of legs see table 2.

Table 2. T. aterrimus. Lengths (in $\mu \mathrm{m}$ ) and proportions of legs.

\begin{tabular}{|c|c|c|c|c|c|c|c|c|c|c|c|}
\hline & $\mathrm{fe}$ & $\mathrm{ti}$ & $\mathrm{ta}_{1}$ & $\mathrm{ta}_{2}$ & $\mathrm{ta}_{3}$ & $\mathrm{ta}_{4}$ & $\mathrm{ta}_{5}$ & LR & BV & SV & $\mathrm{BR}$ \\
\hline $\mathrm{p}_{1}$ & $736-775$ & $413-433$ & $1085-1118$ & $478-543$ & $365-430$ & 284-307 & 129 & $2.58-2.63$ & $1.65-1.78$ & $1.06-1.08$ & $2.7-2.9$ \\
\hline $\mathrm{p}_{2}$ & $720-811$ & $652-694$ & $375-391$ & $213-236$ & $149-168$ & $100-103$ & $80-87$ & 0.57 & $3.17-3.22$ & $3.66-3.79$ & $5.8-6.3$ \\
\hline $\mathrm{p}_{3}$ & $814-898$ & $853-927$ & $585-601$ & $326-352$ & $281-317$ & $174-178$ & $110-113$ & $0.65-0.69$ & $2.51-2.55$ & $2.85-3.04$ & $5.3-5.8$ \\
\hline
\end{tabular}


Hypopygium (fig. 3). - Tergite IX 119-133 $\mu \mathrm{m}$ long with 2 median and 12 apical setae; apical margin without shoulders; lateral teeth not visible; microtrichia absent in small areas on either side of base of anal point. Anal point slender, 66-72 $\mu \mathrm{m}$ long, 16-21 $\mu \mathrm{m}$ wide at base and $6 \mu \mathrm{m}$ wide at apex, with 7-9 spines between well developed anal crests. Anal tergite bands of Y-type. Transverse sternapodeme 51-66 $\mu \mathrm{m}$ long, phallapodeme 117-123 $\mu \mathrm{m}$ long. Gonocoxite 152-170 $\mu \mathrm{m}$ long, gonostylus 150-164 $\mu \mathrm{m}$ long. Superior volsella roughly square; bearing 6 small dorsal setae and 3 median setae; dorsolateral microtrichia absent; digitus long, reaching well beyond median margin of superior volsella, slightly $S$ - shaped with 1 seta placed near base. Median volsella (fig. 4) 51-57 $\mu \mathrm{m}$ long including 2-3, 27-33 $\mu \mathrm{m}$ long, pectinate and setiform lamellae. Inferior volsella slightly $S$ - shaped, 109-111 $\mu \mathrm{m}$ long. HR 1.00-1.04, HV 2.19-2.25.

\section{Remarks}

$T$. aterrimus keys to the $T$. norvegicus species group (Cranston et al. 1989) and fits the group diagnosis (Reiss \& Fittkau 1971) when ignoring the high density of hairs on the wings.

\section{Tanytarsus congus Lehmann}

Tanytarsus congus Lehmann, 1981: 48. Holotype ô (ZSM) Zaire, Kinsangani, Simisimi- stream, 24.III.1975; 1 ô as holotype except 13.III.1975. Both types collected and mounted by J. Lehmann [examined].

Additional material examined: $2 \hat{\sigma}$ (ZMBN) Ghana, Western Region, Ankasa game production reserve, malaise trap, 612.XII.1993; 1 đิ (ZMBN) Ghana, Eastern Region, Kibi, Subri-stream, XI.1993; 10 (ZMBN) Ghana, Central Region, Kakum forest reserve, malaise trap, 8-18.XI.1993; 10 (ZMBN) Senegal, Kedougou, 15.X.1972, leg. C. Dejoux; 10 (ZMBN) Senegal, Dioulacoulon, 21.III.1973, leg. C. Dejoux.

\section{Diagnosis}

T. congus is separable from other Tanytarsus by the following combination of characters: AR $0.60-0.80$;
$\mathrm{LR}_{1}>$ 3.30; hypopygium: Spines in one row between well developed anal crests, superior volsella oval with dorsolateral, small patch of microtrichia, 2 apical seta where 1 is sitting on small ventral projection, digitus with swollen apex reaching beyond superior volsella at its median posterior margin, carrying 1 seta placed at c. $1 / 2$ length of digitus; median volsella relatively short with 3 distal pectinate and 2 normal setae; inferior volsella $S$-shaped.

\section{Description}

Male imago $(\mathrm{n}=4-6)$. - Total length 1.80-2.15, 2.0 $\mathrm{mm}$. Wing length $0.91-1.20,1.06 \mathrm{~mm}$. Total length/wing length 1.85-2.15, 1.94. Coloration. Cleared specimens with light yellowish head, dark brown antennae and eyes; thorax light brown with slightly darker bands dorsally on scutum; legs yellowish with darker apical bands on femur and tibia; wings transparent with somewhat darken veins; abdomen light brown.

Head. - AR 0.61-0.76, 0.68. Thirteenth flagellomere $257-345,315 \mu \mathrm{m}$ long. Longest antennal seta 400-561, $458 \mu \mathrm{m}$ long. Distance between eyes 129$149,139 \mu \mathrm{m}$. Temporal bristles 8-9; 3 inner verticals, 2-3 outer verticals, 3 post orbitals. Clypeus 57-99, 77 $\mu \mathrm{m}$ long with c. 15 setae. Tentorium 73-95, $86 \mu \mathrm{m}$ long, 18-24 $\mu \mathrm{m}$ wide at sieve pore. Stipes 84-100, 94 $\mu \mathrm{m}$ long. Lengths of palpomeres (in $\mu \mathrm{m}$ ): 24-28, 26; 22-28, 26; 66-96, 83; 84-103, 93; 146-180, 161.

Thorax. - Dorsocentrals 5-6, acrosticals 9-10, prealars 1, scutellars 4. 4-5 setae on halteres.

Wing. - VR 1.19-1.34, 1.27. Sc bare, R with 12-17 setae, $\mathrm{R}_{1}$ with $14-18, \mathrm{R}_{4+5}$ with $28-34, \mathrm{M}_{1+2}$ with 24 32, $\mathrm{M}_{3+4}$ with 18-20, Cu with 7-13, $\mathrm{Cu}_{1}$ with 11-16, PCu with 6-26 and An with 12-16 setae. Cells: $m$ with c. 5 setae, $\mathrm{r}_{4+5}$ with c. $70-120, \mathrm{~m}_{1+2}$ with c. $90-150$ including on false vein, $\mathrm{m}_{3+4}$ with c. $40-60$, cu and an combined with c. 20-60 setae.

Legs. - Spur on front tibia 18-33 $\mu \mathrm{m}$ long. Spurs of middle tibia 28-33 $\mu \mathrm{m}$ long including 12-18 $\mu \mathrm{m}$ long comb and 21-29 $\mu \mathrm{m}$ long including 11-15 $\mu \mathrm{m}$ long comb; of hind tibia 33-37 $\mu \mathrm{m}$ including 15-21 $\mu \mathrm{m}$

Table 3. T. congus Lengths (in $\mu \mathrm{m})$ and proportions of legs ( $\mathrm{n}=5$, unless otherwise stated).

$$
\text { fe }
$$$$
\text { ti }
$$

$\mathrm{ta}_{1}$

$\mathrm{ta}_{2}$

$\mathrm{ta}_{3}$

$\mathrm{ta}_{4}$

$\mathrm{ta}_{5}$

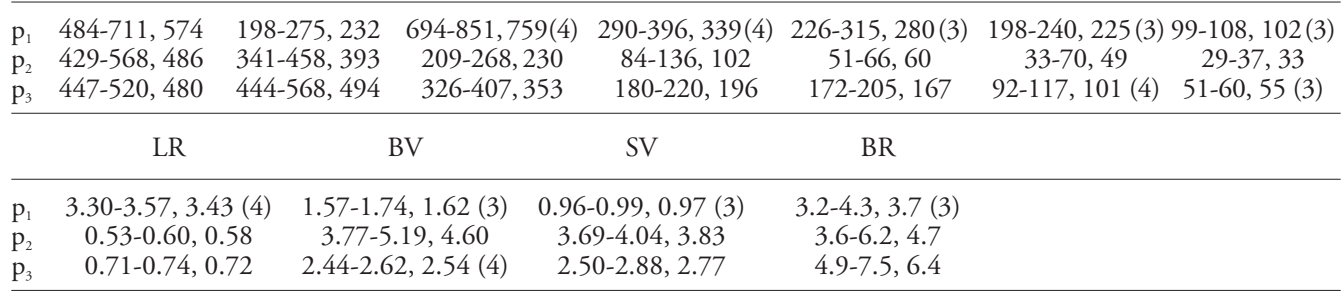


comb and 29-37 $\mu \mathrm{m}$ including 11-18 $\mu \mathrm{m}$ comb. Lengths and proportions of legs see table 3.

Hypopygium (fig. 5). - Tergite IX 74-86, $80 \mu \mathrm{m}$ long with 2-4 median, 10-12 apical setae. Anal point 43-53, $46 \mu \mathrm{m}$ long, 10-18, $15 \mu \mathrm{m}$ wide at base and 4$5 \mu \mathrm{m}$ wide at apex. Anal point with well developed anal crests with 3-7 robust spines in between. Anal tergite bands curved towards but not reaching anal point or connecting with each other. Transverse sternapodeme 33-55, $42 \mu \mathrm{m}$ long, phallapodeme 67-87, $77 \mu \mathrm{m}$ long. Gonocoxite 72-113, $92 \mu \mathrm{m}$ long. Gonostylus 70-87, $81 \mu \mathrm{m}$ long. Superior volsella bearing 5-6 small setae dorsally, one setae apically and one seta venteromedially on a small projection; a small field of microtrichia present laterally. Digitus (fig. 6) long, extending well beyond the median side of superior volsella, with enlarged apex and 1 seta placed at c. $1 / 2$ length. Median volsella short and stump 4-8 $\mu \mathrm{m}$ long with 2 normal setae in addition to 3 strong $10-20 \mu \mathrm{m}$ long pectinate setae. Inferior volsella S-shaped, 57-66, $63 \mu \mathrm{m}$ long, with c. 10 setae where 4 are stronger than the other 6 . HR 1.03-1.32, 1.14; HV 2.41-2.57, 2.50.

\section{Remarks}

$T$. congus keys to the $T$. chinyensis species group (Cranston et al. 1989), and is probably most closely related to T. pseudocongus Ekrem, 1999. At least one Nigerian specimen, labelled 'Tanytarsus congu' collected by Hare in a light trap at Opi Lake (Hare \& Carter 1987) belongs to the probable sister species T. pseudocongus, but it is possible that the other three specimens collected at Opi Lake are $T$. congus since the two species have an overlapping distribution in Ghana. Lehmann (1981) found the larvae of T. congus between moss in fast running areas of the Simisimi Stream.

\section{Tanytarsus elisabethae sp. $\mathrm{n}$.}

Type material. Holotype ơ (BMNH) Nigeria, Opi Lake A, emergence trap, 15-16.IX.1979, leg. L. Hare; 36 paratypes: 40,12 Pex as holotype but collected 14-31.I.1979; 10 with associated Pex as holotype but collected 13-14.I.1979; 1 single reared ô (ZMBM) larva as holotype except 26-29.XI.1978; 1 single reared $q$ pupa as holotype except 15-25.I.1978; $2 \widehat{0}$ (UQC) as previous except 28.I-7.II.1979; $2 \hat{0}, 3$ Pex as previous except 28.I-14.II.1979; 10 as previous except 28.I-7.1979; 1 single reared $q$ larva as previous except 11-18.II.1979; 1 single reared $q$ pupa as previous except 28.I-8.II.1979; 1 single reared + larva as previous except 26-29.XI.1978; 10, 2 Pex mass reared as previous except 14-27.I.1979; 10 as previous except 11-28.II.1979, 1 single reared to larva (ZSM) as previous except 11- 31.III.1979.

\section{Etymology}

Tanytarsus elisabethae is named after my wife and colleague Elisabeth Stur for all help, fruitful scientific discussions and much patience.

\section{Diagnosis}

Tanytarsus elisabethae differs from other Tanytarsus species by the following combination of characters: Wings rather setose, but $\mathrm{Cu}$ almost always bare; frontal tubercles medium long (14-22 $\mu \mathrm{m})$ and slim; $\mathrm{LR}_{1}>3.1$; AR $>1$; scutal tubercle well developed; male anal tergite with two long median setae; anal point long and thin, sometimes missing the usual small spines, small microtrichia-free area at base; superior volsella roughly oval, tapering toward apex, with dorsolateral microtrichia, 3 median, 3-5 dorsal and lateral setae; digitus absent; gonostylus with straight median margin, lateral margin narrowing gradually towards a rather thin apex. Pupa with well developed conical cephalic tubercles; thoracic horn long, thin, with short row of chaetae which are c. $2 \times$ longer than width of horn; posterior thoracic mound weak; precorneals in triangular pattern, two setae usually more than twice as large as third; lateral antepronotal small (c. $27 \mu \mathrm{m})$; armament of tergites consisting of spinules or small spines in elongate, anterior patches; segment VI, VII and VII with 1, 2 and 5 lateral taeniae respectively; anal fringe $<25$, > 16 taeniae. Larval antenna c. $0.7-0.8 \times$ as long as head capsule; Antennal pedestal relatively long, $0.24-0.28 \times$ the length of head capsule. Lauterborn organs small, including pedestals reaching just beyond antennal segment five; SI, SII, chaetae and chaetulae basales plumose, SIII and chaetulae laterales simple; mandible with large apical tooth and one dorsal tooth.

\section{Description}

Male imago ( $\mathrm{n}=10$ unless otherwise stated). - Total length 2.2-2.8, $2.5 \mathrm{~mm}$. Wing length 1.21-1.43, 1.33 $\mathrm{mm}$. Total length/wing length 1.76-1.99. Coloration. Cleared specimens pale greenish with brown eyes.

Head. - Antenna normally developed, AR 1.11-1.23, 1.15. Thirteenth flagellomere 432-540, $498 \mu \mathrm{m}$ long. Longest antennal seta c. $500 \mu \mathrm{m}$ long. Distance between eyes c. $150 \mu \mathrm{m}$. Frontal tubercles medium large, 14-22, $17 \mu \mathrm{m}$ long. Temporal bristles 8-11; 3 inner verticals, 2-4 outer verticals, $2-4$ postorbitals. Clypeus triangular 50-72, $62 \mu \mathrm{m}$ long with 11-16, 14 setae. Tentorium 104-119, $114 \mu \mathrm{m}$ long, $28 \mu \mathrm{m}$ wide at sieve pore. Stipes 119-144, 131 (3) $\mu \mathrm{m}$ long, 14 (3) $\mu \mathrm{m}$ wide. Width of cibarial pump 40-50, $45 \mu \mathrm{m}$. Lengths of palp segments (in $\mu \mathrm{m}, \mathrm{n}=8$ ): 29-36, 32; 29-47, 35; 79-108, 97; 90-115, 102; 158-220, 189 (6).

Thorax (fig. 10). - Scutal tubercle well developed; dorsocentrals 5-7; acrostichals 12-18, 17; prealars 1; scutellars 4-6, 4; halteres with 5-6 setae.

Wing. VR 1.13-1.25, 1.17. Sc bare; R with 18-27, 
23 setae; $\mathrm{R}_{1}$ with 14-26, 20; $\mathrm{R}_{4+5}$ with $32-45$, 39; $\mathrm{M}_{1+2}$ with 33-51, 42; $\mathrm{M}_{3+4}$ with 18-34, 24; Cu with 0-3, 0; $\mathrm{Cu}_{1}$ with 15-20, 18; $\mathrm{PCu}$ with 2-12, 5 and An with 20-26, 23 setae. Cells: $\mathrm{m}$ with $1-11,4$ setae, $r_{4+5}$ with $\mathrm{c}$. $110-160 \mathrm{~m}_{1+2}$ with c. $130-150$ including on false vein, $\mathrm{m}_{3+4}$ with 21-60, 43; cu with 0-30, 9 setae, an bare.

Legs. - Spur on front tibia 32-40, $38 \mu \mathrm{m}$ long including scale. Spurs of middle tibia $36-43 \mu \mathrm{m}$ long including 14-18 $\mu \mathrm{m}$ long comb and 25-32 $\mu \mathrm{m}$ long including 14-18 $\mu \mathrm{m}$ long comb; of hind tibia 36-54 $\mu \mathrm{m}$ long including 114-22 $\mu \mathrm{m}$ long comb and 25-40 $\mu \mathrm{m}$ long including 14-18 $\mu \mathrm{m}$ long comb. Lengths and proportions of legs see table 4.

Hypopygium (figs. 7, 8). - Tergite IX 84-114, 96 $\mu \mathrm{m}$ long with 2 median and 12-17 apical setae; apical margin with weak shoulders; microtrichia absent from a small area around base of anal point. Anal point 50-61, $57 \mu \mathrm{m}$ long, $11 \mu \mathrm{m}$ wide at base and 4$5 \mu \mathrm{m}$ wide at apex. Anal point with 0-3, 2 weak spines between well developed anal crests. Anal tergite bands curved caudally, almost reaching anal point. Transverse sternapodeme 48-61, $55 \mu \mathrm{m}$ long, phallapodeme 95-104, $99 \mu \mathrm{m}$ long. Gonocoxite 109125, $104 \mu \mathrm{m}$ long, gonostylus 91-114, $103 \mu \mathrm{m}$ long. Superior volsella (fig. 9) pear-shaped, tapered towards a median elongated apex; bearing 3-5 small setae dorsally and 3 setae medially with the apical 2 stronger than the basal one; dorsolateral microtrichia present. Digitus absent; median volsella short 32-41, $38 \mu \mathrm{m}$ long including c. 22-27, $25 \mu \mathrm{m}$ long, foliate and simple lamellae. Inferior volsella relatively straight, club shaped, $64-75,70 \mu \mathrm{m}$ long, c. 15 apical setae. HR 1.00-1.28, 1.11; HV 2.12-2.75, 2.43.

Pupa $(\mathrm{n}=8-10)$. - Total length 3.1-3.8, $3.3 \mathrm{~mm}$, abdomen 2.3-2.9, $2.5 \mathrm{~mm}$. Coloration light brown with darker areas around shagreen and spine patches on tergites II through VI. Leg and wing sheaths brown, muscle marks dark brown.

Cephalothorax (fig. 53, 63). - Length of frontal setae 50-83, $69 \mu \mathrm{m}$, cephalic tubercles (fig. 53) well developed, conical, 36-61, $44 \mu \mathrm{m}$ long; pedicel sheath tubercle well developed. Thoracic horn (fig. 58) slender, 396-486, $431 \mu \mathrm{m}$ long, 14-18, $16 \mu \mathrm{m}$ wide, with a short row of 25-36, $34 \mu \mathrm{m}$ long, chaetae. Three precorneals in a triangular pattern anterior and posterior precorneal strong, 65-126, $96 \mu \mathrm{m}$ long, middle precorneal short 29-47, $33 \mu \mathrm{m}$ long; 2 antepronotals visible, median antepronotal 65-83, $77 \mu \mathrm{m}$ long, lateral antepronotal small, 22-32, $27 \mu \mathrm{m}$ long; 2 pairs of dorsocentrals, anterior pair 29-54, 42 (thick) and 4386, 64 (thin) $\mu \mathrm{m}$ long, posterior pair 50-90, 70 (thick) and 40-76, 58 (thick) $\mu \mathrm{m}$ long. Only very litthe granulation dorsal of anterior dorsocentrals. Nose of wing sheath well developed, posterior thoracic mound small 11-18 $\mu \mathrm{m}$ long.

Abdomen (fig. 71). - Shagreen on tergite (T) II as one broad, anterior, transverse band and an additional two posterior, triangular patches; on TII as a transverse band anterior to spine patches. Pedes spurii $B$ on TII well developed; hook row 133-180, $155 \mu \mathrm{m}$ long, c. $1 / 3$ width of TII; length of longest spines/spinules of TIII-TVI (in $\mu \mathrm{m}$ ): 7-14, 12; 14-18, 15; 11-14, 12 and 7; spines of TIII-VI in longitudinal patches, lengths of patches (in $\mu \mathrm{m}$ ): 54-76, 68; 65-90, 76; 58-79, 60 and 32-58, 42. segment II with $2 \mathrm{D}, 2 \mathrm{~V}$ and 3, $25 \mu \mathrm{m}$ long L setae; segment III-V with $5 \mathrm{D}, 2 \mathrm{~V}$ and 3, 30 $\mu \mathrm{m}$ long $\mathrm{L}$ setae; segment VI with $5 \mathrm{D}, 3 \mathrm{~V}$ and 2, 36 $\mu \mathrm{m}$ long $\mathrm{L}$ setae and 1 lateral taeniae, $100-150 \mu \mathrm{m}$ long; segment VII with $5 \mathrm{D}, 3 \mathrm{~V}, 2 \mathrm{~L}$ setae, $36 \mu \mathrm{m}$ long and 2 lateral taeniae, 140-200 $\mu \mathrm{m}$ long; segment VIII with $2 \mathrm{D}, 2$ filamentous V and 5, c. $200 \mu \mathrm{m}$ long lateral taeniae; anal lobe with 2 dorsal, 90-160, 119 $\mu \mathrm{m}$ long taeniae, anal fringe (fig. 78) with 17-23, 20 taeniae, c. 360-460 $\mu \mathrm{m}$ long; posterior lateral comb of segment VIII (fig. 84) 29-47, $35 \mu \mathrm{m}$ wide with 4-7, 5 apical teeth. Lengths of genital sacs: 209-223, $216 \mu \mathrm{m}$

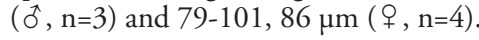

Larva $(n=4)$. - Total length not measurable.

Head. - Length of head capsule 284-295, $289 \mu \mathrm{m}$, width 192-202, $198 \mu \mathrm{m}$, length $/$ width $=1.42-1.50$, 1.46. Antennal pedestal $64-79,74 \mu \mathrm{m}$ long, $0.24-$ $0.28 \times$ the length of head capsule, with longer median

Table 4. T. elisabethae. Lengths (in $\mu \mathrm{m}$ ) and proportions of legs.
fe
ti
$\mathrm{ta}_{1}$

$\mathrm{ta}_{2}$

$\mathrm{ta}_{3}$

$\mathrm{ta}_{4}$

$\mathrm{ta}_{5}$

\begin{tabular}{llllllll}
\hline $\mathrm{p}_{1}$ & $594-724,666$ & $252-328,295$ & $886-1073,987(8)$ & $421-493,459(8)$ & $356-410,389(8)$ & $302-342,328(7)$ & $108-119,117(7)$ \\
$\mathrm{p}_{2}$ & $544-648,606$ & $464-565,517$ & $324-436,369(9)$ & $144-176,160(9)$ & $101-119,110(9)$ & $58-72,65(9)$ & $36-50,45(9)$ \\
$\mathrm{p}_{3}$ & $587-706,660$ & $569-720,657$ & $495-540,520(6)$ & $288-299,291(6)$ & $250-277,259(6)$ & $154-166,160(6)$ & $72-83,78(6)$ \\
\hline
\end{tabular}

\begin{tabular}{ccccc}
\hline & LR & BV & SV & BR \\
\hline $\mathrm{p}_{1}$ & $3.19-3.54,3.33(8)$ & $1.47-1.53,1.52(7)$ & $0.92-1.03,0.98(8)$ & $3.0-5.8,3.8(7)$ \\
$\mathrm{p}_{2}$ & $0.67-0.77,0.71(9)$ & $3.78-4.14,3.93(9)$ & $2.78-3.18,3.07(9)$ & $5.0-6.8,5.8(8)$ \\
$\mathrm{p}_{3}$ & $0.72-0.78,0.76(6)$ & $2.35-2.47,2.41(6)$ & $2.55-2.82,2.65(6)$ & $5.0-7.5,6.4(6)$ \\
\hline
\end{tabular}


margin but without spur. Antenna (fig. 88) 5- segmented, $0.70-0.78 \times$ longer than head capsule; lengths of segments (in $\mu \mathrm{m}, \mathrm{n}=3$ ): 109-132, 124; 27-36, 31; 18-23, 21; 7-11, 10 and 4-5. AR 1.76-1.95, 1.87. Antennal blade $25 \mu \mathrm{m}$ long, antennal seta $25-27 \mu \mathrm{m}$ long, placed at c. $1 / 2$ length of antennal segment 1; Lauterborn organs small, including pedestals reaching just beyond antennal segment 5. Mandible (fig. 98) 89-90 $\mu \mathrm{m}$ long, 41-45 $\mu \mathrm{m}$ wide, with 1 large ventral apical tooth, 3 ventral inner teeth, and 1 dorsal apical tooth present; two outer mandibular setae present; seta subdentalis thick, c. 36-41 $\mu \mathrm{m}$ long and curved; seta interna well developed with 4 main branches. Mentum (fig. 100) 62-66, $64 \mu \mathrm{m}$ wide with 11 teeth; median tooth somewhat paler than other teeth, with lateral notches; ventromental plate 79-85, $82 \mu \mathrm{m}$ wide. Labrum with $S$ I, SII, chaetae and chaetulae basales plumose; S3 long and simple; labral lamella comblike; pecten epipharyngis consisting of three plumose lobes; S III and chaetulae laterales simple; premandible with 5 teeth, premandibular brush well developed; maxilla (fig. 105) with two long and one short lacinial chaetae, palp normally developed.

Body. - Anterior and posterior parapods with simple claws; length of procercus not measurable. Eight anal setae: 3 short, 140-190 $\mu \mathrm{m}$ long and 5 long, 250$420 \mu \mathrm{m}$.

\section{Remarks}

Tanytarsus elisabethae keys to the T. lugens species group (Cranston et al. 1989), but does not fit the group diagnosis in being pale and having a lower AR, fewer spines on anal point, and a different shaped superior volsella (Reiss \& Fittkau 1971). Ignoring the absence of a digitus will place $T$. elisabethae in the more similar T. mendax group (Cranston et al. 1989, Reiss \& Fittkau 1971). The pupa keys to the T. mendax group (Pinder \& Reiss 1986), and the larva has the relatively short Lauterborn organ pedestals which can be diagnostic for the T. mendax group (Ekrem et al. 1999). Among the African Tanytarsus, the male of $T$. elisabethae can be confused with those T. ankasaensis, T. harei and T. formosanus. It differs, however, from $T$. ankasaensis and $T$. formosanus by the missing digitus and differently shaped anal point and from $T$. harei by shape of anal point and the presence of dorsolateral microtrichia on superior volsella. The pupa is probably morphologically closest to $T$. formosanus, but differs by having smaller cephalic tubercles, shorter row of chaetae on thoracic horn, a much smaller middle precorneal and one lateral taenia on segment VI. The larval stage with the combination of a relatively long antennal pedestal, high AR (1.76-1.95), Lauterborn organ pedestals that reach just beyond antennal segment 5 and only one dorsal tooth on mandible can not be confused with any other de- scribed Tanytarsus larvae. Two other morphologically close species are the males of $T$. formosae (Kieffer, 1921) and T. infundibulus Chaudhuri \& Datta (in Datta et al. 1992) which differ in having a more setose wing, differently shaped anal point and missing microtrichia of superior volsella and the males of $T$. nichollsi Glover, 1973 which has pectinate lamellae on a relatively longer and thinner median volsella.

The chironomid fauna composition and the physio-chemical situation of the type locality, Opi Lake A, is described thoroughly by Hare \& Carter (1984; 1987).

\section{Tanytarsus flexistilus Freeman}

Tanytarsus flexistilus Freeman, 1958: 342. Holotype 0 (BMNH) Nigeria, Kankiya, XII.1956-I.1957, leg. B. McMillan; 1 paratype $\delta \hat{~ a s ~ h o l o t y p e . ~}$

Additional material examined: $8 ð$ Ghana, Volta Region, Kpong, Volta River, light trap, 28.XI.1993, leg. NUFU- project; 1 to (ZMBN) Ghana, Northern Region, Sogo, White Volta, light trap, 11.II.1993, leg. NUFU- project; $10 \hat{\text { (UQC) }}$ Nigeria, Opi Lake, emergence trap, 17.III.1977, leg. L. Hare; $80^{*}$ as previous except 20.IV.1977, 13.V.1977, 1524.I.1978, 28.I-7.II.1979, 14-27.I.1979 and 14-31.I.1979. 2 associated larvae with pharate + pupae as previous except 15-18.I.1978 and 26.V-21.VI.1978; 3 associated ox with Pex as previous except 26.IX-5.XII.1978 and 26.XI8.XII.1978; 1 pharate $\hat{\delta}$ pupa as previous except 10 16.XII.1978; 1 single reared to with larval and pupal exuviae as previous, except 15-18.I.1978; 1 single reared $q$ with larval and pupal exuviae as previous, except 28.I-17.II.1979; 2 associated larvae with pharate $\delta$ pupae as previous, except 10-16.XII.1978; 5 Pex as previous, except 13.IV-22.V.1977 and 28.I-7.II.1979; 4 larval exuviae as previous, except 13.IV-22.V.1977, 28.I-7.II.1979 and 25.VI.1980.

\section{Diagnosis}

The species differs from other Tanytarsus species by the following combination of characters: Male hypopygium with 3-7 median setae on anal tergite; anal point long, with only small spines between well developed anal crests; superior volsella well developed, without microtrichia, kidney- shaped, with three median setae, the middle being smaller than the other two; digitus large, thin and almost straight, extending beyond apex of superior volsella; median volsella, large, with at least three subulate lamellae and several additional setiform lamellae. Pupa with long, slender thoracic horns bare or with only few minute chaetae evenly distributed on median half, small cephalic tubercles; pedicel sheath tubercles obvious; large bulbous tubercle on antepronotum; spine patches of tergites III, IV, large with long, anally directed spines; spine patches of tergites $\mathrm{V}$ and VI small to minute with lateral rows of shagreen; one lateral taenia on segment VII, five setae on segment VIII. Larval an- 
tenna longer than head capsule when including Lauterborn organs, only the first and the very basal part of the second antennal segments are well sclerotized; Lauterborn organs minute on pedestals as long as antennal segment two; fine haired premento-hypopharyngeal complex; SI, SII and chaetae plumose, SIII and chaetulae simple; dorsal teeth of mandible double and well developed; maxilla with two large and one small, medially directed lacinial chaetae. Middle tooth of mentum paler than other teeth, with one large notch on either side.

\section{Description}

Male imago $(\mathrm{n}=10)$. - Total length 2.81-3.64, $3.27 \mathrm{~mm}$. Wing length $1.51-1.81,1.66 \mathrm{~mm}$. Total length/wing length 1.81-2.09, 1.96. Coloration. Cleared specimens with head light brown, darker brown pedicel, apodemes and eyes; thorax with dark brown patches anteriorly and laterally on scutum, basally on postnotum and on preepisternum; legs light brown; abdomen pale yellowish.

Head. - Antenna normally developed with AR 1.18-1.47, 1.37. Thirteenth flagellomere 601-675 $\mu \mathrm{m}$ long. Longest antennal seta c. 580-650 $\mu \mathrm{m}$ long. Distance between eyes 178-226 $\mu \mathrm{m}$. Frontal tubercles 16-22 $\mu \mathrm{m}$ long. Temporal bristles 10-12: 2-3 inner verticals, 3-4 outer verticals and 4-6 postorbitals. Clypeus triangular, 68-81 $\mu \mathrm{m}$ long with 11-16 setae. Tentorium 140-171, $160 \mu \mathrm{m}$ long, 36-39 $\mu \mathrm{m}$ wide at sieve pore. Stipes $136-158,148 \mu \mathrm{m}$ long, c. $20 \mu \mathrm{m}$ wide. Cibarial pump 52-68 $\mu \mathrm{m}$ wide. Lengths of palp segments (in $\mu \mathrm{m}$ ): 29-36, 33; 32-36, 35; 97-120, 111; 110-129, 119; 178-245, 208.

Thorax. - Dorsocentrals 7-10, acrostichals 12-17, prealars 1, scutellars 4. Halteres with 6-11 setae.

Wing. - VR 1.17-1.24, 1.20. Brachiolum with 1 seta, $\mathrm{Sc}$ bare, $\mathrm{R}$ with $25-37$ setae, $\mathrm{R}_{1}$ with $28-44, \mathrm{R}_{4+5}$ with 41-76, $M_{1+2}$ with 55-66, $M_{3+4}$ with 33-42, Cu with 18-27, $\mathrm{Cu}_{1}$ with 20-23, PCu with 21-41 and $\mathrm{An}$ with $27-44$ setae. Cell $\mathrm{m}$ with c. 10 setae, $\mathrm{r}_{4+5}$ with $\mathrm{c}$. $150, \mathrm{~m}_{1+2}$ with more than 200 setae including on false vein, $\mathrm{m}_{3+4}$ with c. 60-90, cu and an combined with $\mathrm{c}$. 60-100 setae.
Legs. - Spur on front tibia c. $45 \mu \mathrm{m}$ long including scale. Spurs of middle tibia 36-52 $\mu \mathrm{m}$ long including 13-19 $\mu \mathrm{m}$ long comb and 29-42 $\mu \mathrm{m}$ long including $16-18 \mu \mathrm{m}$ long comb; of hind tibia $42-58 \mu \mathrm{m}$ long including 16-26 $\mu \mathrm{m}$ long comb and 36-52 $\mu \mathrm{m}$ long including 13-26 $\mu \mathrm{m}$ long comb. Middle tibiae with 5-7 sensilla chaeticae. Lengths and proportions of legs see table 5.

Hypopygium (figs. 11, 12). - Tergite IX 125-174, $156 \mu \mathrm{m}$ long with 3-7 median and 14-26 apical setae; apical margin without shoulders; lateral teeth not visible. Anal point 76-94 $\mu \mathrm{m}$ long, narrow, 18-36 $\mu \mathrm{m}$ wide at base and $8-9 \mu \mathrm{m}$ wide at apex. Anal point with 2-6 spines and an extensive field of microtrichia between well developed anal crests. Narrow anal tergite bands curved anally, ending far from anal point. Transverse sternapodeme 53-64 $\mu \mathrm{m}$ long, phallapodeme 119-141 $\mu \mathrm{m}$ long. Gonocoxite 144-194 $\mu \mathrm{m}$ long, gonostylus 139-191 $\mu \mathrm{m}$ long, c. $50 \mu \mathrm{m}$ wide. Superior volsella (fig. 13) kidney- shaped, with concave median margin; bearing 2-3 dorsal setae; 3 lateral setae and 3 median setae where middle seta is shorter than other two; dorsolateral microtrichia absent; digitus long, straight, reaching well beyond apex of superior volsella. Median volsella (fig. 13) 64-86 $\mu \mathrm{m}$ long including 3 subulate and numerous setiform lamellae, 29-49 $\mu \mathrm{m}$ long. Inferior volsella relatively straight, 100-174 $\mu \mathrm{m}$ long, with strong apical setae directed both orally and anally. HR 1.02-1.17, 1.11. HV 2.04-2.35, 2.20.

Pupa $(\mathrm{n}=8-10)$. - Total length 4.5-5.8, $5.2 \mathrm{~mm}$. Coloration light brown, darker areas around shagreen and spine patches on tergites II through VI. Muscle marks dark brown.

Cephalothorax (fig. 54, 64). - Length of frontal setae 43-65, $56 \mu \mathrm{m}$, cephalic tubercles low or absent (fig. 54) < $14 \mu \mathrm{m}$ long. Antepronotum with a large, c. $180 \mu \mathrm{m}$ long and $40 \mu \mathrm{m}$ wide bulbous tubercle. Pedicel sheath tubercle well developed. Thoracic horn (fig. 61) slender, 504-590, $518 \mu \mathrm{m}$ long, 22-29 $\mu \mathrm{m}$ wide, with a few minute, $2-5 \mu \mathrm{m}$ long, chaetae on middle half. Chaetae seems to be absent on some male pupae.

Table 5. T. flexistilus. Lengths (in $\mu \mathrm{m})$ and proportions of legs $(\mathrm{n}=8-10)$.

$$
\mathrm{fe}
$$

$$
\text { ti }
$$

$\mathrm{ta}_{1}$

$\mathrm{ta}_{2}$

$\mathrm{ta}_{3}$

501-565, 543

200-239, 224

336-371, 353

$\begin{array}{ccc}462-520,493 & 368-417,394 & 145-162,156 \\ 165-187,174 & 113-126,119 & 68-72,69 \\ 307-346,326 & 171-226,204 & 97-108,103\end{array}$

307-346, 326

BR

\begin{tabular}{ccccc}
\hline & LR & BV & SV & BR \\
\hline $\mathrm{p}_{1}$ & $2.79-3.10,2.96$ & $1.39-1.61,1.49$ & $0.94-1.03,0.98$ & $2.9-3.7,3.3$ \\
$\mathrm{p}_{2}$ & $0.58-0.64,0.61$ & $3.00-3.26,3.11$ & $3.32-3.58,3.43$ & $2.7-4.5,3.9$ \\
$\mathrm{p}_{3}$ & $0.64-0.71,0.67$ & $2.15-2.43,2.28$ & $2.70-2.99,2.88$ & $3.9-6.7,4.9$ \\
\hline
\end{tabular}


Three precorneals in a triangular pattern on a well developed tubercle, posterior precorneal strong, 101169, $125 \mu \mathrm{m}$ long, anterior two precorneals 29-68, 45 $\mu \mathrm{m}$ and 56-73, $67 \mu \mathrm{m}$ long; 2 lateral antepronotals visible, 1 strong 65-100, $86 \mu \mathrm{m}$ long, 1 seta mark; 2 pairs of dorsocentrals, anterior pair 94-136, 115 and 64-90, $83 \mu \mathrm{m}$ long, posterior pair 61-108, 86 (thin) and 151-187, 168 (thick) $\mu \mathrm{m}$ long. Fine granulation dorsal of anterior dorsocentrals. Nose of wing sheath and prealar tubercle well developed.

Abdomen (fig. 72). - Shagreen on tergite (T) II, two longitudinal bands with enlarged anterior ends; pedes spurii B obvious on TII; hook row 137-216, $174 \mu \mathrm{m}$ long, c. $1 / 3$ width of TII; length of longest spines of TIII-TVI (in $\mu \mathrm{m}$ ): 97-122, 107; 101-133, 116; 11-22, 16 and 4-11, 8; spines of TIII in large, $180-259,230 \mu \mathrm{m}$ long, curved patches on posterior half of tergite; spines of TIV in large, 216-299, 262 $\mu \mathrm{m}$ long, straight patches on middle of tergite; spines of TV and VI in small 43-72, 55 and 22-36, $30 \mu \mathrm{m}$ long patches anterior on tergites; segment II with 2 $\mathrm{D}, 2 \mathrm{~V}$ and 3, $36 \mu \mathrm{m}$ long $\mathrm{L}$ setae; segment III with 5 $\mathrm{D}, 2 \mathrm{~V}$ and 3, 36-54 $\mu \mathrm{m}$ long $\mathrm{L}$ setae; segment IV with $5 \mathrm{D}, 3 \mathrm{~V}$ and 3, 36-54 $\mu \mathrm{m}$ long $\mathrm{L}$ setae; segment $\mathrm{V}$ with $5 \mathrm{D}, 3 \mathrm{~V}$ and 3, 36-54 $\mu \mathrm{m}$ long $\mathrm{L}$ setae; segment VI with $5 \mathrm{D}, 3 \mathrm{~V}$ and 3, 36-54 $\mu \mathrm{m}$ long $\mathrm{L}$ setae; segment VII with $5 \mathrm{D}, 3 \mathrm{~V}, 3 \mathrm{~L}$ setae, 36-54 $\mu \mathrm{m}$ long and 1 lateral taenia, 180-245 $\mu \mathrm{m}$ long; segment VIII with $2 \mathrm{D}, 2$ filamentous $V$ and 5, c. 202-354 $\mu \mathrm{m}$ long lateral taeniae of which the second taenia is placed more medially than the other four; anal lobe with 2 dorsal, 230-324 $\mu \mathrm{m}$ long taeniae, anal fringe with 4560, 500-600 $\mu \mathrm{m}$ long taeniae; posterior lateral comb of segment VIII (fig. 81) wider for females 94-119, $108 \mu \mathrm{m}$ than for males 76-90, $82 \mu \mathrm{m}, 9-13$ apical teeth. Lengths of genital sacs: $256-295 \mu \mathrm{m}(\hat{o}, \mathrm{n}=3)$ and $130-151 \mu \mathrm{m}($ o, $\mathrm{n}=4)$.

Larva $(\mathrm{n}=10)$. - Total length c. $5.5 \mathrm{~mm}$.

Head. - Length of head capsule 353-432, $386 \mu \mathrm{m}$, width $270-328,289 \mu \mathrm{m}$, length/width $=1.24-1.43$, 1.34. Antennal pedestal 54-76, $65 \mu \mathrm{m}$ long, with longer median margin but without spur. Antenna (fig. 86) 5 - segmented, including Lauterborn organs always longer than head capsule; only first and the very basal part of second antennal segment well sclerotized; lengths of segments (in $\mu \mathrm{m}$ ): 230-306, 270; 162-194, 177; 22-36, 32; 9-12, 11 and 4-7, 6. AR 1.05-1.24, 1.18. Antennal blade $46-61,54 \mu \mathrm{m}$ long, antennal seta $25-36,29 \mu \mathrm{m}$ long at $2 / 3$ length of antennal segment 1. Mandible (fig. 96) 122-133, $127 \mu \mathrm{m}$ long with 1 ventral apical tooth, 3 ventral inner teeth, 2 dorsal apical teeth present; two outer mandibular setae present; seta subdentalis thick, c. 41-61, $54 \mu \mathrm{m}$ long and curved, reaching beyond apex of dorsal tooth; seta interna well developed with 4 main branches. Men- tum (fig. 103) 76-97, $89 \mu \mathrm{m}$ wide with 11 teeth; median tooth paler than other teeth, with lateral notches; ventromental plate 111-133, $122 \mu \mathrm{m}$ wide. Labrum (fig. 106) with S I and chaetae plumose; S II plumose, on pedestal; S3 long, simple; labral lamella comblike; pecten epipharyngis consisting of three plumose lobes; chaetulae simple; premandible (figs. 90, 91) with 5 teeth, premandibular brush well developed; maxilla (fig. 104) with two long and one short lacinial chaetae, palp normally developed.

Body. - Anterior and posterior parapods with simple claws; procercus c. $54 \mu \mathrm{m}$ long with one small dorsal and one small lateral seta. Eight anal setae: 3 short, 234-295, $264 \mu \mathrm{m}$ long and 5 long, 504-698, $614 \mu \mathrm{m}$.

\section{Remarks}

Based on adult male characters, Tanytarsus flexistilus keys out to the eminulus-group (Cranston et al. 1989), and the species fits the group diagnosis (Reiss \& Fittkau 1971) except for wing length which is less than $2 \mathrm{~mm}$. Males of $T$. flexistilus are separated from the other species in the T. eminulus-group by having strongly kidney-shaped superior volsella, a medium large median volsella with three subulate and several setiform lamellae and a long, narrow anal point where the crests end at $2 / 3$ length. T. flexistilus keys to the same group based on pupal morphology (Pinder \& Reiss 1986), and can easily be separated from the other species in the eminulus-group by the large sausageformed tubercle on antepronotum. Diagnostic characters for larvae in the T. eminulus-group have not been established.

Opi lake, Nigeria, is the only water body in which larvae of this species have been collected. It is a small lake without permanent surface inlet and experience large fluctuations in water level throughout the year. The water, when measured, was very dilute $(15-24 \mu \mathrm{S}$ $\mathrm{cm}^{-1}$ ) and somewhat acidic ( $\mathrm{pH}$ 6.0-6.5). A thorough description of the physical and chemical conditions of the lake is given by Hare \& Carter (1984). Dejoux (1976b) also found T. flexistilus to be more abundant in light traps at Lake Tchad when the conductivity was $<200 \mu \mathrm{S} \mathrm{cm}^{-1}$. In Opi Lake, the larvae of $T$. flexistilus were more or less restricted to shallow depths < 0.7 m, on muddy substrate (Hare \& Carter 1987).

\section{Tanytarsus formosanus Kieffer}

Tanytarsus formosanus Kieffer, 1912: 42. Lectotype 1 o (DEI) Formosa, Tainan province, Anpin, X. 1908, leg. H. Sauter; 2 paralectotype $\delta$ as lectotype [examined].

Tanytarsus formosae Kieffer, 1923a: 38. Syntypes $2{ }^{\hat{\alpha}}$ (DEI) Formosa, Taihoku province, Daitotei, V.-VI.1914, leg. H. Sauter. [examined] Syn. n.

Tanytarsus horni Goetghebuer, 1934: 39. Holotype ô (NMW) Irak, Basra, 13-15.IV.1926, leg. H. Schmidt; 2 paratype $\delta$ 
(BMNH) as holotype. Syn. $\mathbf{n}$.

Tanytarsus aculeus Chaudhuri et al., 1988: 239. Holotype o (Type no 138, UBI), India, West Bengal, Burdwan University campus, 6.VI.1983, leg. Nandi [not examined]; paratypes: 20, 3 Pex (UBI) India, Burdwan, W. B., 3.V.1979, leg. S. K. Nandi [examined] Syn. n.

Tanytarsus fuscimarginalis Chaudhuri et al. 1984: 33. Holotype ơ (Type no 64, UBI), India, West Bengal, Bolpur, 18.VIII.1977, leg. D. Chatterje [examined]; paratypes: 10 (UBI) as holotype [examined]; 10 (UBI) India, West Bengal, Burdwan, 3.VII.1978, leg. M. Gosh [examined] Syn. n.

Tanytarsus nigrocinctus Freeman, 1957a: 220. Holotype o (BMNH) Uganda, Lake Victoria, 4.V.1952 (synonymised by Reiss \& Fittkau 1971) [examined]; 1 paratype $\delta$ (BMNH) Kenya, Kitui, 29.VI.1953 [examined]. Freeman, 1958: 339; Dejoux, 1968b: 449.

Tanytarsus horni; Reiss \& Fittkau, 1971: 121 (adult male, ecology). Cranston \& Judd, 1989: 268 (adult male, distribution). Langton, 1991: 357 (pupa). Verschuren, 1997: 500 (larva)

Additional material examined: - AFRICA: $30 \hat{~(Z S M) ~ A l g e-~}$ ria, Berbessa, by Montebello Plaine de la Mitidja, 24.VII.1955, leg. Clastrier; 31 ô (ZMBN) Ghana, Volta Region, Kpong, Volta River, Light trap, 28.XI.1993, leg. NUFUproject; 1 o (ZSM) Kenya, N. Mombasa, Gei Hotel Malaika, IV.1995, leg. G. Riedel; $1 \hat{\delta}$ (ZSM) Marocco, area around Tetnan, 6.VI.1968, leg. Choumara; 10 (ZSM) Marocco, Rabat, 24.V.1968, leg. Choumara; 10 (ZSM) Sudan, Blue Nile, nr Singa, Ummbenane, 25.II.1981, leg. P. Mellor. - WEST PALAEARCTIC: $11 \mathrm{Pex}$ and 10 $\hat{\sigma}^{\circ}$ (ZSM) France, Camargue, Piscine Hoffmar, 10.VII.1965, leg. Laville; 30 (ZSM) Spain, Marismas des Quadalquivir, o.d., leg. Tourenq; 5 Pex and $2 \hat{0}$ (ZSM) Italy, Sicily, Segesta, Austr. Stream, 5.IX.1952, leg. E. J. Fittkau; 10 (BMNH) Saudi Arabia, E. Province, Hofuf, $25^{\circ} 24^{\prime} \mathrm{N} 49^{\circ} 28^{\prime} \mathrm{E}, 28 . V .1978$, leg. W. Buttiker; $10^{\text {to }}$ as previous except 18.IX.1985; 20 as previous except 26.VI.1978; $20^{\top}$ (BMNH) Saudi Arabia, Jawf, Al Jawf, 2952'N 3953'E, 610 m, 1-2.XI.1986, leg W. Buttiker; $30^{\wedge}$ (BMNH) Saudi Ara-

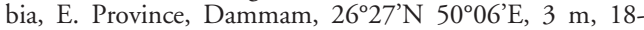
19.V.1979, leg. W. Buttiker; $10^{\top}$ (вMNH) Saudi Arabia, E. Province, Haradl, $24^{\circ} 09^{\prime} \mathrm{N} 49^{\circ} 04^{\prime} \mathrm{E}, 310$ m, o.d., leg. W. Buttiker; 1 to (ZSM) Turkey, Adana, 14.IX.1982, leg. R. Kinzelbach; - SOUTH ASIA: 1 oे (ZSM) India, Mandapam, 30 31.I.1958. $10^{\star}$ (ZSM) Thailand, Dai Inthanou, 1219.IX.1989; 1 ô (ZSM) Thailand, Sob Pong, 23.XII.1989, leg. H. Malicky; $1 \hat{\delta}$ (ZSM) Thailand, Chatrakan, 810.XII.1989, leg. H. Malicky; $1 \delta^{\star}$ (ZSM) Thailand, Ayutthaya, 3.IV.1989, leg H. Malicky; 1 o (ZSM) China, Province Yunnan, Buynan, Mung Lun River, 27.V.1980, leg. E. J. Fittkau; $1 \delta^{\star}$ (ZSM) China, Province Hunan, Taoyuan, 2.VI.1980, leg. E. J. Fittkau; 1 đ (ZSM) China, Province Hunan, 1.VI.1980, leg. E. J. Fittkau.

\section{Diagnosis}

T. formosanus Kieffer is separable from other Tanytarsus species by the following combination of characters: Head with large frontal tubercles; usually strong thoracic colorations anteriorly and dorsolaterally on scutum, basally on scutellum, postnotum, median anepisternum II, epimeron II and on preepisternum; tergites II-IV with broad median longitudinal stripe and an broad, transverse stripe posteriorly; tergites V-VI with an additional, narrow, anterior transverse stripe; tergite VII with an anterior transverse stripe and tergite VIII with two large lateral pigmented spots; wings with sparse setation (restricted to apical $1 / 3$ ), Cu bare, cell $r_{4+5}$ with more or equal amount of setae as cell $\mathrm{m}_{1+2} ; \mathrm{AR}>1$; hypopygium: Spines in one row between well developed anal crests; superior volsella tapered towards apex which is somewhat median elongated, with lateral microtrichia, 6-8 dorsal setae of which 3 are placed laterally, 3 median setae where the two most apical are larger than the innermost seta; digitus fairly short, not reaching apex of superior volsella; median volsella relatively short with 4-6 broad, distally pointed lamellae and 1520 setiform lamellae. Pupa with large conical cephalic tubercles; long evenly tapered thoracic horn, chaetae longer than width of horn in one row on $\mathrm{mid}^{2 / 3}$; strong armament on tergite III and IV with long spines in separate, longitudinal rows occupying $1 / 3-1 / 2$ length of tergite; segment VII with 2 anterior L setae and 2 posterior lateral taeniae, segment VIII with 5 lateral taeniae.

\section{Description}

Male imago ( $\mathrm{n}=17-18$ unless otherwise stated). The specimens used in the description are purposely selected from the different localities I have had access to. Total length $2.5-3.9,2.9 \mathrm{~mm}$. Wing length 1.35 $2.24,1,61 \mathrm{~mm}$. Total length/wing length $1.59-2.12$, 1.9. Coloration. Cleared specimens with head light brown, darker brown antennae and eyes; thorax and abdomen as described in diagnosis.

Head. - Antenna normally developed, AR 1.09$1.46,1.28$ (15). Thirteenth flagellomere 446-682, $551(15) \mu \mathrm{m}$ long. Longest antennal seta c. 450-600 $\mu \mathrm{m}$ long. Distance between eyes 170-268, $196 \mu \mathrm{m}$. Large frontal tubercles c. 32-60 $\mu \mathrm{m}$ long. Temporal bristles $8-15$; 1-4 inner verticals, 4-6 outer verticals, 2-5 postorbitals. Clypeus 58-97, 67 (13) um long with 15-22 setae. Tentorium 123-161, 142 (14) $\mu \mathrm{m}$ long, 36-42 $\mu \mathrm{m}$ wide at sieve pore. Stipes 110-145, 133 (9) $\mu \mathrm{m}$ long. Cibarial pump with 2 pairs of venterolateral sensorial setae, width of cibarial pump 45 $68,55(13) \mu \mathrm{m}$. Lengths of palp segments (in $\mu \mathrm{m})$ : 29-36, 32 (14); 29-36, 34 (14), 64-97, 78 (12); 71113,90 (12); 129-178, 155 (8).

Thorax. - Dorsocentrals 7-13, acrostichals 12-22, prealars 1. Scutellum with 4-8 setae. 4-7 setae on halteres.

Wing. - VR 1.04-1.16, 1.12. Sc without setae, R with $13-29,18$ setae, $R_{1}$ with $1-30,16 ; R_{4,5}$ with 10 23, $16(16) ; M_{1+2}$ with $14-52,30 ; M_{3+4}$ with $0-26,9$; Cu bare, $\mathrm{Cu}_{1}$ with 0-19, 6 setae, $\mathrm{PCu}$ with $0-5,1$ and An with $0-30,16$ setae. Cells: $m$ bare, $r_{4+5}$ with c. $80-$ 160 setae, $m_{1+2}$ with $80-170$ including on false vein, $\mathrm{m}_{3+4}$ with $0-17, \mathrm{cu}$ and an always bare.

Legs. - Spur on front tibia 29-42 $\mu \mathrm{m}$ long including scale. Spurs of middle tibia $29-42 \mu \mathrm{m}$ long including $13-19 \mu \mathrm{m}$ long comb and 26-36 $\mu \mathrm{m}$ long in- 
cluding 13-19 $\mu \mathrm{m}$ long comb; of hind tibia 29-55 $\mu \mathrm{m}$

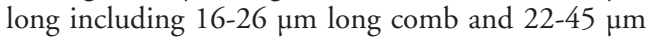
long including 16-23 $\mu \mathrm{m}$ long comb. Lengths and proportions of legs see table 6 .

Hypopygium (fig. 14). - Tergite IX 109-162, 129 $\mu \mathrm{m}$ long with $0-5$ (usually 2 ) median and 10-20 (usually 14-16) apical setae; apical margin with two shoulders on each side of the anal point; two lateral teeth often clearly recognizable; microtrichia absent on a large area around base of anal point. Anal point 41-76, $58 \mu \mathrm{m}$ long, $14-24 \mu \mathrm{m}$ wide at base and 6-8 $\mu \mathrm{m}$ wide at apex. Anal point with 3-9 robust spines between well developed anal crests. Anal tergite bands curved towards almost reaching anal point and sometimes showing a median elongation without connecting with each other. Transverse sternapodeme 41-80 $\mu \mathrm{m}$ long, phallapodeme 103-144 um long. Gonocoxite 127-205, 153 $\mu \mathrm{m}$ long. Gonostylus 103-193, $134 \mu \mathrm{m}$ long. Superior volsella (figs. 15, 16) tapered towards apex, with median elongation, 3-9 dorsal, 3-4 ventral and 3 median setae where the apical 2 are much stronger than the basal one; microtrichia present laterally and ventrolaterally. Digitus fairly small, not extending beyond the median margin of superior volsella. Median volsella short 5182, $62 \mu \mathrm{m}$ long including 4-6 broad, $18-41,30 \mu \mathrm{m}$ long, pointed lamellae in addition to c. 15-20 setiform lamellae (see Reiss \& Fittkau 1971: 181, fig. 33a). Inferior volsella somewhat club-shaped, 86-144, $103 \mu \mathrm{m}$ long, with strong setae directed orally. HR 1.06-1.32, 1.16; HV 1.93-2.60, 2.25.

Pupa ( $\mathrm{n}=8-9$ unless otherwise stated). - Total length 4.2-4.7, $4.4 \mathrm{~mm}$ (5). Coloration light brown, apodemes and armament dark brown.

Cephalothorax (fig. 52, 67). - Length of frontal setae $68-101,80 \mu \mathrm{m}$, cephalic tubercles large and conical, 48-72, 57 (5) $\mu \mathrm{m}$ long. Pedicel sheath tubercle (fig. 52) prominent, c. $1 / 3$ length of cephalic tubercles. Thoracic horn (fig. 59) evenly tapered, 432-646, 497 $\mu \mathrm{m}$ long, 25-32, $29 \mu \mathrm{m}$ wide, with a longitudinal row of $32-54,41 \mu \mathrm{m}$ long chaetae situated on $\mathrm{mid}^{2 / 3}-3 / 4.3$ precorneals all equally long, 86-155, $108 \mu \mathrm{m}$, placed in a triangular pattern; antepronotals 1 median 61-97, 79 (4) $\mu \mathrm{m}$ long, 2 lateral $14 \mu \mathrm{m}$ and 48-72, 62 (5) $\mu \mathrm{m}$ long; 2 pairs of dorsocentrals with 1 thin and 1 thick seta in each pair, thin setae c. 50-100 $\mu \mathrm{m}$ long, thick setae c. 40-70 $\mu \mathrm{m}$.

Abdomen (figs. 69, 77). - Anterior, transverse band of shagreen on T II, anterior patches of shagreen on T III and VIII, S VIII and dorsally on anal lobe; pedes spurii B present on segment II and III; T II with 2 longitudinal brown point patches, hook row 151-271, 201 $\mu \mathrm{m}$ long; spines of T III 68-103, $80 \mu \mathrm{m}$ long, in separate longitudinal rows covering $1 / 3-1 / 2$ of length of tergite, bending slightly laterally in posterior part of spine patch, spines of T IV 29-97, $63 \mu \mathrm{m}$ long in separate, straight longitudinal rows or patches covering $1 / 4-1 / 2$ of length of tergite, spines of T V and VI 14-29, 22 and $10-22,16 \mu \mathrm{m}$ long, in anterior, small circular patches; segment II with $3 \mathrm{D}, 3 \mathrm{~V}$ and $3 \mathrm{~L}$ setae $18-43,30 \mu \mathrm{m}$ long; segment III with $5 \mathrm{D}, 2 \mathrm{~V}$ and $3 \mathrm{~L}$ setae $32-47,38$ $\mu \mathrm{m}$ long, 1-2 small sensorial setae between spine patches; segment IV with, $5 \mathrm{D}, 3 \mathrm{~V}, 1-2$ sensorial setae and 3 $\mathrm{L}$ setae 36-55, $45 \mu \mathrm{m}$ long; segment $\mathrm{V}$ with $6 \mathrm{D}, 3 \mathrm{~V}, 2$ sensorial and $3 \mathrm{~L}$ setae 29-71, $46 \mu \mathrm{m}$ long; segment VI with $5 \mathrm{D}, 4 \mathrm{~V}, 2$ sensorial and $3 \mathrm{~L}$ setae 29-90, $51 \mu \mathrm{m}$ long; segment VII with 4 D, 4 V, 2 L setae 29-87, 55 $\mu \mathrm{m}$ long and 2 lateral taeniae 108-234, $160 \mu \mathrm{m}$ long; segment VIII with 1-2 dorsal taeniae 100-178, 140 (5) $\mu \mathrm{m}$ long, $1-2 \mathrm{~V}, 5$ lateral taeniae c. 180-280 $\mu \mathrm{m}$ long; anal lobe with 2 dorsal taeniae 162-291, $242 \mu \mathrm{m}$ long; anal fringe with 35-50, 43 taeniae, c. 390-610 $\mu \mathrm{m}$ long; posterior lateral comb of segment VIII 54-84, $68 \mu \mathrm{m}$ wide with teeth 14-29 $\mu \mathrm{m}$ long.

Larva. Described by Dejoux (1968b), Chaudhuri et al. (1988) and Verschuren (1997).

\section{Remarks}

Nomenclature and taxonomy. - Although Kieffer described Tanytarsus formosanus, he did not designate holo- or paratypes in his description. However, 126 out of 135 specimens in the Sauter collection (DEI) do carry 'holotype' or 'paratype' labels. Dr. F. Menzel,

Table 6. T. formosanus. Lengths (in $\mu \mathrm{m}$ ) and proportions of legs.
fe
ti
$\mathrm{ta}_{1}$
$\mathrm{ta}_{2}$
$\mathrm{ta}_{3}$
$\mathrm{ta}_{4}$
$\mathrm{ta}_{5}$

\begin{tabular}{|c|c|c|c|c|c|}
\hline$p$ & 497-769, & 72 & (13) 368 & 310 & 1) 97 \\
\hline$P$ & $510-814,641$ & 604 & $317-449,369(16) 181$ & $139-216,169(15)$ & $97-152,115(15) \quad 58-100,72(15)$ \\
\hline $\mathrm{n}$ & $607-943,716$ & $659-1066,794$ & $481-714,538(12) \quad 281-443,330(12)$ & $252-381,288(12)$ & $161-242,184(12) 87-129,99(12)$ \\
\hline
\end{tabular}

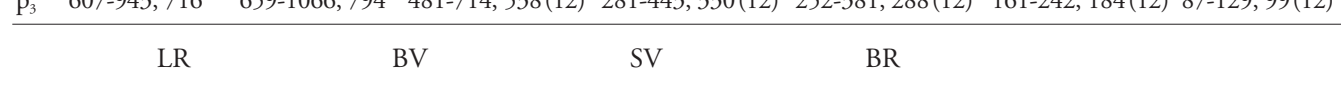

\footnotetext{
$\mathrm{p}_{1} \quad 1.94-2.77,2.34(13) \quad 1.36-1.54,1.47$ (11) $1.03-1.27,1.14(11) \quad 2.6-5.0,3.7$ (13)

$\mathrm{p}_{2} \quad 0.57-0.65,0.62$ (16) $2.51-3.04,2.87$ (15) $3.20-3.60,3.42$ (15) $3.0-7.0,5.0(15)$

$\mathrm{p}_{3} \quad 0.64-0.72,0.68(12) \quad 2.02-2.43,2.27$ (12) $2.61-2.95,2.80(12) \quad 4.0-6.0,5.3(10)$
} 
responsible for the Diptera collection in Eberswalde, states that a labelling mistake by a former curator probably has been made. Therefore, the 135 specimens in the type-series collected by H. Sauter and identified by Kieffer must be regarded as syntypes. I designate a lectotype from the type series in order to fix the identity of the species. The rest of the 135 species in the type series collected X.1908 and II.1909 are paralectotypes. Seven of the 127 specimens of the Sauter collection were collected X.1912, after Kieffer's August 1921 description and thus cannot be part of the type series. Two specimens from the type series are deposited in BMNH, five in MNHN , one in NMW, and seven specimens of the type series have an unknown location.

Cranston \& Judd (1989) segregated 10 specimens from Saudi Arabia as intermediates between T. horni Goetghebuer and T. mcmillani Freeman based on missing lateral microtrichia on the superior volsella of the hypopygium. Closer examination of the specimens with an interference contrast microscope, shows that microtrichia indeed are present. In addition, other characters such as wing setation and size of frontal tubercles clearly separate these specimens from the $T$. momillani type specimens examined (see description of $T$. momillani). The intermediate specimens described as Tanytarsus ?horni by Cranston and Judd (1989) all belong to the species T. formosanus Kieffer.

The paratypes and descriptions of $T$. aculeus are impossible to differentiate from $T$. formosanus and the synonymies should be granted although the holotype has been unavailable for examination. One specimen of $T$. agraensis from Bolpur carries a paratype label, but is obviously no paratype since it was collected August 1979 by D. Sinharay while the paratypes were collected in April 1974 (Singh \& Kulshrestha 1975). Although the specimens labelled T. agraensis obviously belongs to $T$. formosanus, and the description and drawings by Singh $\&$ Kulshrestha (1975) fit the diagnostics of $T$. formosanus, a synonymy has to await examination of the type material.

Both pupae and male adults of T. formosanus obviously key to the T. mendax-group (Cranston et al. 1989; Pinder \& Reiss 1986) since T. horni originally was placed in this group by Reiss \& Fittkau (1971).

Ecology. - Although T. formosanus seems to be more abundant in less dilute waters (Verschuren 1997), it is also found in Opi Lake $\left(15-25 \mu \mathrm{S} \mathrm{cm}^{-1}\right)$ (Hare \& Carter 1987). The highest conductivity in which larvae have been found is $868 \mu \mathrm{S} \mathrm{cm}^{-1}$ at Lake Awasha, Ethiopia (Kibret \& Harrison 1989). The larvae have been recorded from both sandy and muddy bottoms with coarse organic debris (Dejoux 1976b, Hare \& Carter 1987, Verschuren 1997), and have at least in one lake shown intolerance to daily oxygen fluctuations (Petr 1972).

Tanytarsus formosanus is, despite its name, also well distributed in Africa and most southern parts the Palaearctic region.

\section{Identity of Rheotanytarsus formosae Kieffer, 1921}

Examination of Tanytarsini type material from Formosa (now Taiwan) revealed a few taxonomic problems that need to be solved. Kyerematen et al. (2000) examined the type material of Rheotanytarsus formosae Kieffer, 1921, and found it to belong to the genus Tanytarsus. This makes T. formosae (Kieffer, 1921) a senior secondary homonym of $T$. formosae Kieffer, 1923a. T. formosae Kieffer, 1923a is found to be a synonym of T. formosanus Kieffer, 1912 (see above), and thus does not need a replacement name (ICZN 1999). Re-examination of the type material of $T$. formosae (Kieffer, 1921) revealed that it consists of two species. In the material, one adult male is labelled 'holotype' and one female plus four males are labelled 'paratype'. Kieffer did not design any holo- or paratypes, and according to Dr. F. Menzel, DEI (pers. comm.), a former curator probably made a labelling mistake. All type specimens of $T$. formosae (Kieffer, 1921) are therefore to be regarded as syntypes. I designate one to be lectotype in order to fix the identity of the species, and therefore the remainding specimens of the series are paralectotypes. The paralectotypes include, however, two different morphotypes: two male specimens are conspecific with the lectotype and one male is conspecific with $T$. gracistylus Chaudhuri \& Datta (in Datta et al. 1992). The female and damaged males are impossible to identify.

\section{Tanytarsus harei sp. $\mathrm{n}$.}

Tanytarsus (holochlorus gp.) n. spp. (2) Hare \& Carter, 1987: 69.

Type material: Holotype ô (BMNH) Nigeria, Opi Lake, 20-21.IV.1980, emergence trap, leg. L. Hare. 3 paratypes: 10 (UQC) as holotype except 2-3.IV.1980 in light trap; $1 \hat{0}$ (ZMBN) Senegal, Kedougou, 15.X.1972, leg. C. Dejoux; 10 (ZMBN) Côte d'Ivoire, Zoba (Man), 10.II.1981, leg. C. Dejoux.

\section{Etymology}

The species is named after Dr. Landis Hare who generously provided me with valuable reared material of several Tanytarsus species from Opi Lake in Nigeria. 


\section{Diagnosis}

The new species differs from other Tanytarsus species by the following combination of characters: Eyes without dorsomedian extension; AR c. $0.9 ; \mathrm{LR}_{1} \mathrm{c}$. 2.6; wings with only a few setae at wing tip; hypopygium: 2 median setae on anal tergite, large microtrichia-free area around anal point; anal point with 4-5 large, trifid spines between well developed anal crests; superior volsella pear- shaped, tapering anally, with 4-5 dorsal setae, microtrichia absent; digitus absent; median volsella medium large with several foliate and simple lamellae.

\section{Description}

Male imago ( $\mathrm{n}=2$ unless otherwise stated). - Total length 1.9-2.0 mm. Wing length 0.99-1.04 mm. Total length/wing length 1.8-1.9. Coloration. Body, legs and head light greenish, eyes brown.

Head. - Antenna normally developed, AR 0.90-0.93. Ultimate flagellomere 342-367 $\mu \mathrm{m}$ long. Eyes without dorsomedian extension; distance between eyes 187$205 \mu \mathrm{m}$. Frontal tubercles present, 15-25 $\mu \mathrm{m}$ long. Temporal bristles 8 ; including 2-3 inner verticals, 3 outer verticals and 2-3 postorbitals. Clypeus semicircular, 58-61 $\mu \mathrm{m}$ long with 9-10 setae. Tentorium 72-86 $\mu \mathrm{m}$ long, 20-22 $\mu \mathrm{m}$ wide at sieve pore. Stipes $97 \mu \mathrm{m}$ long, 7-11 $\mu \mathrm{m}$ wide. Cibarial pump 36-40 $\mu \mathrm{m}$ wide. Lengths of palpomeres (in $\mu \mathrm{m}$ ): 22, 25-29, 72-79, 3897, 130-151.

Thorax. - Scutal tubercle absent. Dorsocentrals 56 , acrostichals $12-14$, prealars 1 , scutellars 2 , halteres with 5 setae.

Wing. - VR 1.14-1.16. Sc bare, $\mathrm{R}$ with 12-19 setae, $R_{1}$ with 7-10; $R_{4+5}$ with 8-9 setae; $M$ bare; $M_{1+2}$ with 2021 setae; $\mathrm{M}_{3+4}$ with 3-7; $\mathrm{Cu}_{1}$ with $0-3$ setae; $\mathrm{Cu}, \mathrm{PCu}$ and An bare. Cell $\mathrm{m}$ bare, $\mathrm{r}_{4+5}$ with 62-65 setae, $\mathrm{m}_{1+2}$ with 35-48 including on false vein, $\mathrm{m}_{3+4,} \mathrm{cu}$ and an bare.

Legs. - Spur on front tibia 22-26 $\mu \mathrm{m}$ long including scale. Spurs of middle tibiae 16-26 $\mu \mathrm{m}$ long including $10 \mu \mathrm{m}$ long comb; of hind tibiae $22-30 \mu \mathrm{m}$ long including $13 \mu \mathrm{m}$ long comb. Lengths and proportions of legs see table 7 .

Hypopygium (fig. 17). - Tergite IX 75-82 $\mu \mathrm{m}$ long with 2 median setae, 14 apical setae; apical margin with small lateral shoulders; no lateral teeth visible; large microtrichia-free area around base of anal point.
Anal point 41-52 $\mu \mathrm{m}$ long, $11 \mu \mathrm{m}$ wide at base, 6-9 $\mu \mathrm{m}$ wide at apex. Anal point with 4-5 large trifid spines between well developed anal crests. Anal tergite bands caudally curved, almost reaching median setae of anal point, no median elongation. Transverse sternapodeme 34-39 $\mu \mathrm{m}$ long; phallapodeme 75-82 $\mu \mathrm{m}$ long. Gonocoxite 77-100 $\mu \mathrm{m}$ long, gonostylus straight with widest width in middle, 73-95 $\mu \mathrm{m}$ long. Superior volsella (fig. 18) pear- shaped, tapering anally; bearing 4-5 dorsal setae and 3 median setae, middle seta weaker and situated close and below basal seta; dorsolateral microtrichia absent; digitus absent. Median volsella $46 \mu \mathrm{m}$ long including 5-6, $23 \mu \mathrm{m}$ long foliate and 5-6 simple lamellae. Inferior volsella medially curved, 46-52 $\mu \mathrm{m}$ long, with strong apical setae. HR 1.05-1.06; HV 2.1-2.6.

\section{Remarks}

Based on the adult male morphology, Tanytarsus hare $i$ keys to the $T$. mendax species group if the absence of a digitus is ignored (Cranston et al. 1989), and fits the group diagnosis if one ignores the smaller size and lower AR value (Reiss \& Fittkau 1971). These characters seems to be good specific characters, but probably not suitable for group diagnosis on a world wide basis. The morphological closest species are probably $T$. formosae (Kieffer, 1921) and T. infundibulus Chaudhuri \& Datta (in Datta et al. 1992) which only differ in having a more setose wing and a higher AR value, and T. nichollsi Glover, 1973 which has pectinate lamellae on a relatively longer and thinner median volsella. Among the Afrotropical species, T. harei comes closest to $T$. formosanus, T. elisabethae and T. ankasaensis but differs from $T$. formosanus in being smaller, lacking a digitus, having a green body and lacking dorsolateral microtrichia on superior volsella, from $T$. elisabethae by lacking dorsolateral microtrichia on superior volsella and having a differently shaped anal point, and from $T$. ankasaensis in lacking a digitus, lacking dorsolateral microtrichia on superior volsella and in having a much lower $\mathrm{LR}_{1}$ value.

The chironomid fauna composition and the physio-chemical situation of the type locality, Opi Lake A, is described thoroughly by Hare \& Carter (1984, 1987).

Table 7. T. harei. Lengths (in $\mu \mathrm{m}$ ) and proportions of legs

\begin{tabular}{|c|c|c|c|c|c|c|c|c|c|c|c|}
\hline & $\mathrm{fe}$ & $\mathrm{ti}$ & $\mathrm{ta}_{1}$ & $\mathrm{ta}_{2}$ & $\mathrm{ta}_{3}$ & $\mathrm{ta}_{4}$ & $\mathrm{ta}_{5}$ & LR & BV & SV & BR \\
\hline p & $450-468$ & $09-234$ & 160 & $3(1)$ & $245(1)$ & $216(1)$ & $97(1)$ & 2.6 & 1.5 & $1.14(1)$ & $3.7(1)$ \\
\hline $\mathrm{p}_{2}$ & $446-468$ & $378-392$ & 248 (1) & $151(1)$ & $74(1)$ & 54 (1) & $40(1)$ & $0.63(1)$ & 3.47 & $3.47(1)$ & - \\
\hline $\mathrm{p}_{3}$ & $475-504$ & $479-518$ & 364 (1) & 209 (1) & $187(1)$ & $126(1)$ & $72(1)$ & $0.70(1)$ & $2.33(1)$ & $2.81(1)$ & $6.0(1)$ \\
\hline
\end{tabular}




\section{Tanytarsus luctuosus Freeman}

Tanytarsus luctuosus Freeman, 1958: 339. Holotype $ぇ$ (BMNH) Cape Province, Platteklip Gorge, 22.I.1953, leg. K. M. F. Scott [examined]; paratype 1 ô (BMNH) Transvaal, Magoebaskloof, nr. Tzaneen, 6.V.1955, leg. A. D. Harrison [examined].

Additional material examined: $1 \hat{\delta}$ (ZSM) Zaire, Kivu-area, Kalengo, 11.IV.1972, leg. J. Lehmann, $1 \hat{\delta}^{\hat{0}}$ as previous except 12.VI.1972, 1 pharate $\delta$ as previous except 9.IX.1972, 10 (ZMBN) Tanzania, Tanga. W. Usambara, Mazumbai, Loc. N8, XI.1990, leg. ZMBN's Tanzania expedition.

\section{Diagnosis}

The species differs from other Tanytarsus species by the following combination of characters: adult male with broad, transverse, brown pigmented bands on all tergites; wing relatively hairy, but cell $\mathrm{m}$ is bare; scutal tubercle present; frontal tubercles minute, only visible as two white dots; hypopygium with 2-4 median setae on anal tergite, anal point with 6-10 spines between well developed anal crests; superior volsella with small median tubercle, 5-7 dorsal setae and numerous dorsolateral microtrichia, digitus absent; median volsella large with numerous long, slender, simple lamellae which reaches beyond apex of inferior volsella. Pupal thoracic horn bare, 3 strong precorneals, cephalic tubercles developed; tergites III-VI with pairs of oval spinule patches; tergite III almost covered with shagreen, small points between spinule patches; tergites IV-VI with fields of shagreen around spinule patches; hook row large, $3 / 4$ of segment width.

Male imago ( $\mathrm{n}=3-4$ unless otherwise stated). Total length $2.5-2.8 \mathrm{~mm}$. Wing length $1.30-1.69$, $1.55 \mathrm{~mm}$. Total length/wing length 1.6-1.7. Coloration. Live specimens black; cleared specimens with head light brown, darker brown antennae and eyes; thorax dark brown; legs and halteres light brown; abdominal tergites with broad, transverse, dark band.

Head. - Antenna normally developed with AR 0.81.07, 0.99. Ultimate flagellomere 310-533, $469 \mu \mathrm{m}$ long. Longest antennal seta c. $550 \mu \mathrm{m}$ long. Distance between eyes c. 160-180 $\mu \mathrm{m}$. Minute frontal tubercles only visible as two white dots. Temporal bristles 9-10; including 3 inner verticals, 3-4 outer verticals and 3 postorbitals. Clypeus triangular, 52-55 (2) $\mu \mathrm{m}$ long with 11-14 (2) setae. Tentorium 120 (2) $\mu \mathrm{m}$ long, 29-32 (2) $\mu \mathrm{m}$ wide at sieve pore. Stipes 107-136 (2) $\mu \mathrm{m}$ long, 13 (2) $\mu \mathrm{m}$ wide. Cibarial pump 45-48 (2) $\mu \mathrm{m}$ wide. Lengths of palpomeres I-IV (in $\mu \mathrm{m}$ ): 29-32 (2), 36 (2), 136 (1), 120 (1), 210 (1).

Thorax. - Scutal tubercle present. Dorsocentrals 69, acrostichals $10-17$, prealars 1, scutellars 4-6. Halteres with 4-8 setae.

Wing. - VR 1.13-1.18. Sc bare, R with 16-31, 24 setae, $\mathrm{R}_{1}$ with $15-19,17 ; \mathrm{R}_{4+5}$ with $16-29,22$ setae; $\mathrm{M}$ bare; $M_{1+2}$ with 34-68, 50 setae; $M_{3+4}$ with 15-36, 25; Cu with 0-11, 4; $\mathrm{Cu}_{1}$ with 10-21, 17; PCu with 1-24, 13 and An with 13-48, 28 setae. Cell $m$ bare, $r_{4+5}$ with c. $120-180$ setae, $\mathrm{m}_{1+2}$ with c. $140-220$ including on false vein, $\mathrm{m}_{3+4}$ with $\mathrm{c}$. $30-80$ and $\mathrm{cu}+$ an together with $0-60$ setae.

Legs. - Spur on front tibia 29-42 $\mu \mathrm{m}$ long including scale. Spurs of middle tibia 19-29 $\mu \mathrm{m}$ long including 10-16 $\mu \mathrm{m}$ long comb; of hind tibia $39 \mu \mathrm{m}$ long including $16 \mu \mathrm{m}$ long comb. Lengths and proportions of legs see table 8 .

Hypopygium (fig. 21). - Tergite IX 82-103, 95 $\mu \mathrm{m}$ long with 2-4 median setae, 10-14 apical setae; apical margin without lateral shoulders; lateral teeth not visible; microtrichia-free area between anal crests. Anal point 39-55, $45 \mu \mathrm{m}$ long, 12-16 $\mu \mathrm{m}$ wide at base and 6-8 $\mu \mathrm{m}$ wide at apex. Anal point with 6-10 spines between well developed anal crests. Anal tergite bands caudally curved, not reaching anal point, with median elongations almost connecting tergite bands. Transverse sternapodeme 31-41, $38 \mu \mathrm{m}$ long; phallapodeme seems forked, 92-109, $100 \mu \mathrm{m}$ long, both branches being equally long. Gonocoxite 113$135,126 \mu \mathrm{m}$ long, gonostylus sausage- shaped, 113$135,127 \mu \mathrm{m}$ long. Superior volsella more or less oval with small tubercle on median margin (figs. 22, 23); bearing 7 dorsal setae and 3 median setae, the apical 2 somewhat stronger than the basal one; dorsolateral

Table 8. T. luctuosus. Lengths (in $\mu \mathrm{m}$ ) and proportions of legs.

\begin{tabular}{|c|c|c|c|c|c|c|c|}
\hline & $\mathrm{fe}$ & $\mathrm{ti}$ & $\mathrm{ta}_{1}$ & $\mathrm{ta}_{2}$ & $\mathrm{ta}_{3}$ & $\mathrm{ta}_{4}$ & $\mathrm{ta}_{5}$ \\
\hline $\mathrm{p}_{1}$ & $568-694,643$ & $313-323,318$ & $646-933,836$ & $355-533,464$ & $281-417(2)$ & $200-317(2)$ & $87-129(2)$ \\
\hline $\mathrm{p}_{2}$ & $552-688,614$ & $510-581,543$ & $342(1)$ & $178(1)$ & $120(1)$ & $71(1)$ & $58(1)$ \\
\hline \multirow[t]{2}{*}{$\mathrm{p}_{3}$} & $694-759,728$ & $730-766,744$ & $501(1)$ & $320(1)$ & $268(1)$ & $171(1)$ & $90(1)$ \\
\hline & LR & & V & SV & $\mathrm{BR}$ & & \\
\hline $\mathrm{p}_{1}$ & $2.06-2.92,2.6$ & $1.40-$ & $65,(2)$ & $1.07-1.37,1.18$ & $4.5-5.8(2)$ & & \\
\hline $\mathrm{p}_{2}$ & $0.59(1)$ & & $7(1)$ & $3.70(1)$ & $5.0(1)$ & & \\
\hline $\mathrm{p}_{3}$ & $0.65(1)$ & & $(1)$ & $3.04(1)$ & $7.3(1)$ & & \\
\hline
\end{tabular}


microtrichia present; digitus absent. Median volsella (fig. 24) 88-96, $93 \mu \mathrm{m}$ long including c. 10, 40-50 $\mu \mathrm{m}$ long, simple lamellae reaching beyond apex of inferior volsella. Inferior volsella, club- shaped, medially curved, 80-92, $86 \mu \mathrm{m}$ long, with strong apical setae. HR 0.95-1.03, 0.99; HV 2.0-2.5, 2.2.

Pupa ( $\mathrm{n}=1)$. - Length of abdomen $2.0 \mathrm{~mm}$. Coloration pale with brown areas on cephalothorax. Muscle marks dark brown.

Cephalothorax (fig. 65). - Length of frontal setae $103 \mu \mathrm{m}$, cephalic tubercles round, medium high. Thoracic horn $517 \mu \mathrm{m}$ long, $36 \mu \mathrm{m}$ wide, bare. Three precorneals in a triangular pattern; 2 antepronotals visible, 1 median and 1 lateral; 2 pairs of dorsocentrals. Fine granulation dorsal of anterior dorsocentrals.

Abdomen (fig. 75). - Tergite (T) II with one anterior and one posterior transverse band of shagreen, one pair of anterior spinule patches with somewhat stronger shagreen in between; hook row $200 \mu \mathrm{m}$ long, c. $3 / 4$ width of TII; length of longest spinules of TIITV (in $\mu \mathrm{m}$ ): 6, 6, 13 and 10; spinules of TII and III in small, circular patches; patches on TIV-V more elongate; patches on TVI not visible; $3 \mathrm{D}$ setae seen on TII and III; segment VIII with 5 lateral taeniae; anal fringe with c. 24 taeniae; posterior lateral comb of segment VIII (fig. 85) c. $32 \mu \mathrm{m}$ wide, with 4 apical teeth.

\section{Remarks}

Unfortunately, only one pharate male was available for examination of pupal characters and several characters normally included in a description could not been seen or measured. Based on the adult male morphology, Tanytarsus luctuosus keys to the T. lugens species group (Cranston et al. 1989), but does not fit the group diagnosis (Reiss \& Fittkau 1971) in having AR $<1.4$, smooth apex of anal point and a particularly large median volsella with numerous simple setae. T. luctuosus share these characters with its probable sister species T. usambarae Stur \& Ekrem, 2000, but differs by having a median tubercle on the superior volsella, all blackish brown abdominal tergites, and a scutal tubercle. T. luctuosus and T. usambarae co- exist in the West Usambara Mts., and both were found in the material collected by the same Malaise trap. The pupa keys to the T. mendax species group (Pinder $\&$ Reiss 1986), but does not resemble the pupa of any other species in the group. If one ignores the developed cephalic tubercles, pupa of T. luctuosus will key to the T. curticornis species group (Pinder $\&$ Reiss 1986). Apart from the cephalic tubercles, the pupa is quite similar to pupae of the other species in this group, especially by the shape of the thoracic horn and the tergite armament. Further decision on the systematic placement of $T$. luctuosus has to await a phylogenetic analysis of the genus.

\section{Tanytarsus momillani Freeman}

Tanytarsus momillani Freeman, 1958: 341. Holotype $\widehat{0}$ (BMNH) Nigeria, Kankiya, XII.1956-I.1957, leg. B. McMillan; paratypes: $2 \delta^{\hat{\sigma}}$ as holotype and $1 \delta^{\hat{\sigma}}$ (BMNH) Nigeria, Kaduna, 19.X.1956, leg. B. McMillan [all examined].

Tanytarsus atroxitarsus Chaudhuri \& Datta, in Datta et al., 1992: 42. Holotype ô (Type no. 196, UBI) India, W. Bengal, Jalpaiguri, $26^{\circ} 16^{\prime} \mathrm{N} 88^{\circ} 25^{\prime} \mathrm{E}, 68.5 \mathrm{~m}$ a.s.l., 22.III.1988, leg. A. K. De [examined]; paratype ${ }^{\star}(\mathrm{UBI})$ as holotype except collected in Birpara, $26^{\circ} 43^{\prime} \mathrm{N} 89^{\circ} 8^{\prime} \mathrm{E}$, $117.8 \mathrm{~m}$ a.s.l., 14.X.1990, leg. T. K. Datta [examined] Syn. n.

Additional material examined: 10 (BMNH) Saudi Arabia, Medina, W. J. 12.1, 264의 $37^{\circ} 15^{\prime} \mathrm{E}, 1000 \mathrm{~m}$ a.s.l., 14.XI.1984, leg. W. Buttiker, 10 (BMNH) Saudi Arabia, Makkah, W. Maraum, $22^{\circ} 16^{\prime} \mathrm{N} 39^{\circ} 44^{\prime} \mathrm{E}, 280 \mathrm{~m}$ a.s.l., 34.V.1984, leg. W. Buttiker, 1 ऊิ (ZSM) Kamerun, Adamaoua, 31.IV.1979, leg. W. Flauke \& P. Nagel.

\section{Diagnosis}

The species differs from other Tanytarsus species by the following combination of characters: frontal tubercles well developed; AR > 1.0; wings hairy, c. 10-15 setae in cell $\mathrm{m}$; hypopygium with 2-8 median setae on triangular anal tergite, anal point with 4-7 small spines between well developed anal crests; microtrichia present around base of anal point; superior volsella oval with parallel sides, bearing c. 7 dorsal setae, microtrichia absent; small digitus present; median volsella medium large with several foliate and simple lamellae.

\section{Description}

Male imago ( $\mathrm{n}=7$ unless otherwise stated). - Total length $2.7-3.2,3.0 \mathrm{~mm}$. Wing length $1.30-1.75$, $1.60(8) \mathrm{mm}$. Total length/wing length 1.8-2.0. Coloration. African specimens seems to be somewhat darker with brown thoracic markings and transverse stripes on tergites. Indian specimens yellowish.

Head. - Antenna normally developed with AR 1.08-1.37, 1.25. Ultimate flagellomere 340-581, 516 $\mu \mathrm{m}$ long. Longest antennal seta 340-550 $\mu \mathrm{m}$ long. Distance between eyes c. $150 \mu \mathrm{m}$. Frontal tubercles large, $19-23 \mu \mathrm{m}$ long. Temporal bristles 9-12; including 3-5 inner verticals, 2-4 outer verticals and 2-4 postorbitals. Clypeus semicircular, 58-72, 65 (6) $\mu \mathrm{m}$ long with 10-20, 15 setae. Tentorium 144-161, 155 $\mu \mathrm{m}$ long, 26-48, $38 \mu \mathrm{m}$ wide at sieve pore. Stipes 139-174, 161 (6) $\mu \mathrm{m}$ long, 13-19, 15 (4) $\mu \mathrm{m}$ wide. Cibarial pump 58-74, 66 (5) $\mu \mathrm{m}$ wide. Lengths of palpomeres (in $\mu \mathrm{m}$ ): $26-43,36 ; 32-43,40 ; 110-133$, 126; 113-144, 136; 203-245, 222 (5).

Thorax. - Scutal tubercle absent. Dorsocentrals 812 , acrostichals $13-17$, prealars 1 , scutellars $4-8$. Halteres with 5-6 setae.

Wing $(\mathrm{n}=8)$. - VR 1.15-1.26, 1.19. Sc bare, $\mathrm{R}$ with 20-36, 27 setae, $\mathrm{R}_{1}$ with $24-36,29 ; \mathrm{R}_{4+5}$ with 46-58, 
52 setae; $M$ bare; $M_{1+2}$ with 50-70, 60 setae; $M_{3+4}$ with 21-44, 37; Cu with 11-27, 18; $\mathrm{Cu}_{1}$ with 20-27, 24; $\mathrm{PCu}$ with 14-42, 24 and An with 32-44, 36 setae. Cell $m$ with 5-15 setae, $r_{4+5}$ with c. $130-200, m_{1+2}$ with $c$. 190-250 including on false vein, $m_{3+4}$ with c. 60-100 and $\mathrm{cu}$ and an combined with 40-100 setae.

Legs. - Spur on front tibia 36-42 $\mu \mathrm{m}$ long including scale. Spurs of middle tibia $32-42 \mu \mathrm{m}$ long including 16-19 $\mu \mathrm{m}$ long comb and 23-36 $\mu \mathrm{m}$ long including 16-18 $\mu \mathrm{m}$ long comb; of hind tibia 36-50 $\mu \mathrm{m}$ long including $18-25 \mu \mathrm{m}$ long comb and 29-42 $\mu \mathrm{m}$ long including $16-23 \mu \mathrm{m}$ long comb. Lengths and proportions of legs see table 9 .

Hypopygium (fig. 25). - Tergite IX triangular, 114146, $128 \mu \mathrm{m}$ long with 2-8, 4 median setae, 14-20, 16 apical setae; apical margin without lateral shoulders; two lateral teeth often visible; microtrichia-free area between anal crests, microtrichia present around base of anal point. Anal point 57-76, $67 \mu \mathrm{m}$ long, 18-23 $\mu \mathrm{m}$ wide at base and 6-10 $\mu \mathrm{m}$ wide at apex. Anal point with 4-7, 5 spines between well developed anal crests. Anal tergite bands caudally curved, reaching median setae of anal point, no median elongation. Transverse sternapodeme 51-72, 63 (6) $\mu \mathrm{m}$ long; phallapodeme 105-129, 118 (6) $\mu \mathrm{m}$ long. Gonocoxite 133-160, 143 $\mu \mathrm{m}$ long, gonostylus with widest width in middle, 123$164,143 \mu \mathrm{m}$ long. Superior volsella oval with parallel sides, bearing 7 dorsal setae and 3 median setae, the middle one somewhat stronger than the other two; dorsolateral microtrichia absent; digitus present, c. half the length of superior volsella. Median volsella (fig. 26) 60-72, $63 \mu \mathrm{m}$ long including 3-4 foliate and 12-16, 27-39, $30 \mu \mathrm{m}$ long, simple lamellae. Inferior volsella, club- shaped, relatively straight, 72-100, $91 \mu \mathrm{m}$ long, with strong apical setae. HR 1.00; HV 1.9-2.2, 2.1.

\section{Remarks}

Datta et al. (1992) described T. atroxitarsus from India as a separate species, but examination of the holotype and one paratype has shown that the diagnostic characters they used are either not species specific or have been misinterpreted. The 'digitus' of $T$. atroxitarsus pictured in Datta et al. (1992: 58, fig. 5) has upon examination of the specimen used to create the drawing, been identified as a dorsal fold of the superior volsella, and a result of the mounting procedure. Based on the adult male morphology, Tanytarsus momillani keys to the $T$. lugens species group (Cranston et al. 1989), but does not fit the group diagnosis (Reiss \& Fittkau 1971) in having AR < 1.4, smooth apex of anal point and a digitus which is $\mathrm{c}$. half the length of superior volsella. A certain group placement has to await a phylogenetic analysis of the genus.

\section{Tanytarsus spadiceonotatus Freeman}

Tanytarsus spadiceonotatus Freeman, 1958: 341. Holotype Oे (BMNH) Nigeria, Kankiya, XII.1956-I.1957, leg. B. McMillan, paratype $2 \hat{\sigma}$ and $2+$ as holotype [examined].

Additional material examined: $2 \hat{\sigma}$ (ZSM) Ghana, Volta Region, Lake Volta, 5.VII.1966, leg. T. Petr, 1 đo (ZSM) Tchad, Tchadsee, Fort Lamy, 15.V.1965, leg. C. Dejoux, 10 (ZSM) South Africa, Krüger National Park, 2.V.1991, UV-Light Trap, leg. I. Pajor.

\section{Diagnosis}

The species differs from other Tanytarsus species by the following combination of characters: frontal tubercles well developed; AR > 1.0; wings with only a few setae on wing tip; hypopygium with 2-4 median setae on anal tergite, anal point with 4-7 small spines between well developed anal crests; superior volsella almost quadrate, posteromedian corner drawn out to a median directed point, 4-6 dorsal setae, microtrichia absent; small, rounded digitus present; median volsella medium large with several foliate and simple lamellae; 3 inner setae on gonocoxite, gonostylus long, narrow and parallel sided. Pupal thoracic horn with long chaetae (at least $2 \times$ longer than width of horn) in one row; small cephalic tubercles; pedicel sheath tubercles obvious; spine patches of tergites III, IV, large with long, anally directed spines; spine patches of tergites $\mathrm{V}$

Table 9. T. momillani. Lengths (in $\mu \mathrm{m}$ ) and proportions of legs.

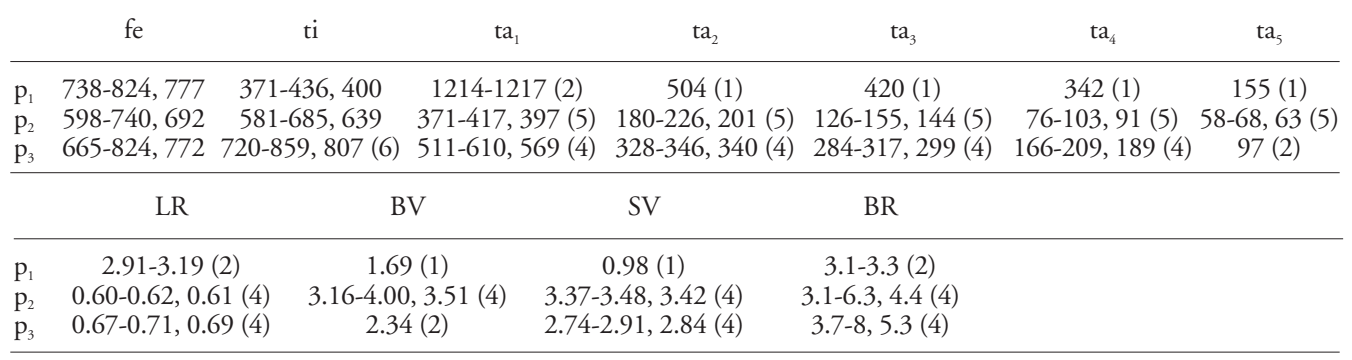


and VI small to minute with lateral rows of shagreen; 2-3 lateral taeniae on segment VII, five on segment VIII; less than 15 taeniae in anal fringe. Larval antenna longer than head capsule when including Lauterborn organs, only the first and $2 / 3$ of the second antennal segments are well sclerotized; Lauterborn organs minute on pedestals as long as antennal segment two + three; AR > 2.0; SI, SII, chaetae and chaetulae basales plumose, SIII and chaetulae laterales simple; mandible with one dorsal tooth well developed, two small spines basally on mola; premandible with four teeth; maxilla with two large and one small, medially directed lacinial chaetae. Middle tooth of mentum paler than other teeth, one large notch on either side.

Male imago ( $\mathrm{n}=6$ unless otherwise stated). - Total length 2.4-2.8, 2.6 (5) $\mathrm{mm}$. Wing length 1.25$1.40,1.30 \mathrm{~mm}$. Total length/wing length $1.8-2.2$, 2.0 (5). Coloration. Cleared specimens with head pale, antennae and eyes brown; thorax pale with brown patches anteriorly and laterally on scutum, on median anepisternum II, preepisternum, epimeron II, postnotum and basally on scutellum and anepisternum; abdominal tergites with posterior, brown transverse stripe.

Head. - Antenna normally developed, AR 1.03-1.12, 1.06. Ultimate flagellomere 365-452, $430 \mu \mathrm{m}$ long. Longest antennal seta c. $500 \mu \mathrm{m}$ long. Distance between eyes c. 184-216, $200 \mu \mathrm{m}$. Frontal tubercles well developed, c. $15 \mu \mathrm{m}$ long. Temporal bristles 10-11; including 3-4 inner verticals, 3-4 outer verticals and 3-4 postorbitals. Clypeus semicircular, 48-74, $55 \mu \mathrm{m}$ long with 11-15 setae. Tentorium 113-129, 123 (5) $\mu \mathrm{m}$ long, 23-29, 26 (5) $\mu \mathrm{m}$ wide at sieve pore. Stipes 8794, 91 (4) $\mu \mathrm{m}$ long, 10 (4) $\mu \mathrm{m}$ wide. Cibarial pump 48-52, 50 (4) $\mu \mathrm{m}$ wide. Lengths of palpomeres (in $\mu \mathrm{m}): 23-29$; 26-32; 52-64, 57 (5); 68-81, 77 (5); 113$132,126(4)$.

Thorax. - Scutal tubercle absent. Dorsocentrals 48 , acrostichals 9-12, prealars 1 , scutellars 4 . Halteres with 3-4 setae (3).

Wing. - VR 1.17-1.31, 1.24. Sc bare, R with 0-12,
6 setae, $\mathrm{R}_{1}$ with $0-2,0 ; \mathrm{R}_{4+5}$ with 1-11, 6 setae; $\mathrm{M}$ bare; $\mathrm{M}_{1+2}$ with 20-25, 23 setae; $\mathrm{M}_{3+4}$ with $0-5,2 ; \mathrm{Cu}_{1}$ with 0-6, 2 setae; $\mathrm{Cu}, \mathrm{PCu}$ and $\mathrm{An}$ bare. Cell $\mathrm{m}$ bare, $r_{4+5}$ with c. 30-50 setae, $m_{1+2}$ with c. 20-40 including on false vein, $\mathrm{m}_{3+4}$ with $0-2$ setae and $\mathrm{cu}+$ an bare.

Legs. - Spur on front tibia 26-32 $\mu \mathrm{m}$ long including scale. Spurs of middle tibia 16-19 $\mu \mathrm{m}$ long including 10-13 $\mu \mathrm{m}$ long comb; of hind tibia $23-32 \mu \mathrm{m}$ long including 13-16 $\mu \mathrm{m}$ long comb. Middle tibia with 5-6 sensilla chaeticae. Lengths and proportions of legs see table 10 .

Hypopygium (fig. 35). - Tergite IX 98-115, 107 $\mu \mathrm{m}$ long with 2-4 median setae, 10-14 apical setae; apical margin without lateral shoulders; microtrichiafree area between anal crests. Anal point 47-70, 54 $\mu \mathrm{m}$ long, $14-21,16 \mu \mathrm{m}$ wide at base and 6-8 $\mu \mathrm{m}$ wide at apex. Anal point with 4-7, 5 spines between well developed anal crests. Anal tergite bands caudally curved, not reaching median setae of anal point, no median elongation. Transverse sternapodeme 39-47, $42 \mu \mathrm{m}$ long; phallapodeme 92-100, $96 \mu \mathrm{m}$ long. Gonocoxite 111-123, 117 (5) $\mu \mathrm{m}$ long with three inner setae, gonostylus sausage- shaped, 109-119, 113 (5) $\mu \mathrm{m}$ long. Superior volsella almost quadrate, posteromedian corner drawn out to a median directed point, 4-6 dorsal setae, microtrichia absent; small rounded digitus present. Median volsella (fig. 36) $37-$ $47,41 \mu \mathrm{m}$ long including 3-4 falciform and 8-10, 16$25 \mu \mathrm{m}$ long, simple lamellae. Inferior volsella relatively straight, 66-82, $77 \mu \mathrm{m}$ long, with strong apical setae. HR 0.97-1.09, 1.03 (5); HV 2.11-2.39, 2.25 (4).

Female paratypes do exist but can not be associated with males with certainty.

Pupa $(\mathrm{n}=10)$. - Total length 3.2-4.0, $3.8 \mathrm{~mm}$; abdomen length 2.5-3.0, 2.6. Coloration light brown with darker areas around shagreen and spine patches on tergites II through VI. Muscle marks dark brown.

Cephalothorax (fig. 57, 66). - Length of frontal setae 45-62, $52 \mu \mathrm{m}$, cephalic tubercles low 18-22, 19 (fig. 57). Pedicel sheath tubercle well developed. Tho-

Table 10. T. spadiceonotatus. Lengths (in $\mu \mathrm{m}$ ) and proportions of legs.

fe ti 274-300, 288 $410-475,452$ 543-656, 613 ta

$\mathrm{ta}_{2}$ 636-717, 683(5) 310-352, 338(5) $252-258,255(3) \quad 132-139,136(3)$ 384-417, 398(4) 194-258, $229(4)$ $\mathrm{ta}_{3}$

$\mathrm{ta}_{4}$

$\begin{array}{ccc}258-297,276(5) & 178-197,191(5) & 81-97,89(5) \\ 97(3) & 64-71,66(3) & 55(3) \\ 178-223,204(4) & 129-139,133(3) & 71-84,75(3)\end{array}$

BR

$\begin{array}{lllll}\mathrm{p}_{1} & 2.21-2.51,2.37(5) & 1,57-1.71,1.63(5) & 1.06-1.22,1.14(5) & 3.1-3.3,3.2(4) \\ \mathrm{p}_{2} & 0.56-0.61,0.58(3) & 3.10-3.38,3.28(3) & 3.40-3.65,3.53(3) & 4.5-5.5,4.9(3) \\ \mathrm{p}_{3} & 0.63-0.66,0,65(4) & 2.28-2.57,2.41(3) & 2.79-2.97,2.89(4) & 5.5-7.3,6.2(3)\end{array}$


racic horn (fig. 60) 360-504, $438 \mu \mathrm{m}$ long, 22-29, 25 $\mu \mathrm{m}$ wide, with a row of $112-152,126 \mu \mathrm{m}$ long chaetae basal $2 / 3$. Three precorneals in a triangular pattern, posterior precorneal, 76-112, $88 \mu \mathrm{m}$ long, anterior two precorneals 50-79, $63 \mu \mathrm{m}$ and 50-94, $68 \mu \mathrm{m}$ long; 1 lateral antepronotals visible 47-70, $54 \mu \mathrm{m}$ long, 1 median anteprotonal 47-76, 61; 2 pairs of dorsocentrals, anterior pair 36-61, 47 (thin) $\mu \mathrm{m}$ and 3654, 42 (thick) $\mu \mathrm{m}$ long, posterior pair 47-72, 62 (thin) and 54-72, 64 (thick) $\mu \mathrm{m}$ long. Fine granulation along scutal suture. Nose of wing sheath and prealar tubercle well developed.

Abdomen (fig. 70, 79). - Shagreen on tergite (T) II as in fig. 70; pedes spurii B absent; hook row 90-126, $106 \mu \mathrm{m}$ long, c. $1 / 3$ width of TII; length of longest spines of TIII-TVI (in $\mu \mathrm{m}$ ): 61-90, 68; 43-61, 51; 1018, 13 and 7-11, 8; spines of TIII in large, 137-176, $154 \mu \mathrm{m}$ long, diagonal patches on posterior half of tergite; spines of TIV in large, 154-202, $172 \mu \mathrm{m}$ long, straight patches on middle of tergite; spines of TV and VI in small 40-54, 47 and 22-36, $31 \mu \mathrm{m}$ long patches anteriorly on tergites; segment II-VI with 3, $30 \mu \mathrm{m}$ long L setae; segment VII sometimes with one L setae, c. $45 \mu \mathrm{m}$ long and 2-3 lateral taeniae, c. 160-200 $\mu \mathrm{m}$ long; segment VIII with 5, c. 230-300 $\mu \mathrm{m}$ long lateral taeniae; anal lobe with 2 dorsal, 234-450, 330 (8) $\mu \mathrm{m}$ long taeniae, anal fringe with $10-14,11$ c. $250-300$ $\mu \mathrm{m}$ long taeniae; posterior lateral comb of segment VIII (fig. 83) 43-72, 54 (9) $\mu \mathrm{m}$ wide with 9-14 (9) apical teeth. Lengths of genital sacs: 202-234, $217 \mu \mathrm{m}$ $(\hat{o}, \mathrm{n}=4)$ and $90-94,92 \mu \mathrm{m}(+, \mathrm{n}=5)$.

Larva ( $\mathrm{n}=10$ unless otherwise stated). - Total length c. $3,8 \mathrm{~mm}$.

Head. - Length of head capsule 252-274, $263 \mu \mathrm{m}$, width 198-216, $209 \mu \mathrm{m}$, length/width $=1.24-1.31$, 1.27. Antennal pedestal 66-90, $78 \mu \mathrm{m}$ long, with an indication of a medially directed spur. Antenna (fig. 87) 5- segmented, including Lauterborn organs always longer than head capsule; only first and basal $2 / 3$ of second antennal segment well sclerotized; lengths of segments (in $\mu \mathrm{m}$ ): 124-156, 138; 34-50, 40; 9-14, 13 (8); 5-7, 5 (8) and 2-3, 3 (8). AR 2.05-2.43, 2.27 (8). Antennal blade 16-30, 26 (8) $\mu \mathrm{m}$ long, antennal seta $30-$ $52,43(7) \mu \mathrm{m}$ long at $2 / 3$ length of antennal segment 1 . Mandible (fig. 97) 89-100, 93 (9) $\mu \mathrm{m}$ long, 43-57, 46 (9) wide with 1 ventral apical tooth, 3 ventral inner teeth, and 1 dorsal apical tooth present; two basal molar spines; two outer mandibular setae present; seta subdentalis thick, c. 41-45, $43 \mu \mathrm{m}$ long and curved, reaching beyond apex of dorsal tooth; seta interna well developed with 4 main branches. Premandible (fig. 92) with 4 teeth. Mentum (fig. 102) 54-68, $60 \mu \mathrm{m}$ wide with 11 teeth; median tooth paler than other teeth, with lateral notches; ventromental plate 83-93, $87 \mu \mathrm{m}$ wide. Labrum with S I, SII, chaetae and chaetulae basales plumose; chaetulae laterales simple; S3 long and simple; labral lamella comblike; pecten epipharyngis consisting of three plumose lobes; maxilla with two long and one short lacinial chaetae, palp normally developed.

Body. - Anterior and posterior parapods with simple claws; procercus c. 54 (1) $\mu \mathrm{m}$ long with one small dorsal and one small lateral seta. Seven anal setae: 4 short, c. 140-200 $\mu \mathrm{m}$ and 3 long, c. $280-330 \mu \mathrm{m}$ long. Four large anal tubules c. 144 (1) mm long.

\section{Remarks}

Based on the adult male morphology, Tanytarsus spadiceonotatus keys to the $T$. lugens species group (Cranston et al. 1989), but does not fit the group diagnosis (Reiss \& Fittkau 1971) in having AR $<1.4$, smooth apex of anal point, an almost quadrate superior volsella and in being smaller than the European species in the group. Ignoring the small digitus, $T$. spadiceonotatus will key to the $T$. mendax group (Cranston et al. 1989), but differs from the other members in this group in having smaller frontal tubercles, no digitus and a different shape of the superior volsella. The pupae of $T$. spadiceonotatus will key to the $T$. eminulus species group when regarding the cephalic tubercles to be low and the spine patches of TIII to be posteriorly diverging. The single row of long chaetae on the thoracic horn, however, is a character typical for members of the $T$. mendax group. It is not possible to indicate a placement for the larva of T. spadiceonotatus yet, and a conclusive systematic placement for this species has to await a phylogenetic analysis of the genus Tanytarsus.

\section{Tanytarsus trifidus Freeman}

Tanytarsus trifidus Freeman, 1958: 343. Holotype $\delta$ (BMNH) Nigeria, Kankiya, XII.1956- I.1957, leg. B. McMillan; paratypes $2 \hat{\sigma}$ as holotype and $1 \delta^{\hat{\sigma}}$ as holotype except in Nigeria, Zaria, XII.1956 [examined].

Additional material examined: $5 \hat{\jmath}$ (ZMBN) Ghana, Central Region, Kakum forest reserve, Malaise trap, 8.-18. XI.1994, leg. NUFU- project; 50 (ZMBN) Ghana, Western Region, Ankasa game production reserve, Malaise trap, $7-$ 11.XII.1993, leg. NUFU- project; 10 (UQC) Nigeria, Opi Lake, emergence trap, 26.III.1977, leg. L. Hare; $90 \hat{~}$ as previous except 10.V.1977, 13-26.V.1977, 27.IV-10.V.1978, 12 22.XI.1978, 14-27.I.1979, 14-31.I.1979 and 9-10.II.1980; $1 \%$ as previous except 26.III.1977; 2 associated $q$ with Pex as previous except 21-27.V.1978 and 9-11.XII.1978; 2 associated of with Pex as previous except 10.V.1978 and 1420.I.1979; $10 \mathrm{Pex}$ as previous except 13.IV-17.V.1977, 28.1-7.II.1979 and 14-31.I.1979; 1 single reared of with larval and pupal exuviae as previous, except 28.IV.1977. 


\section{Diagnosis}

Tanytarsus trifidus differs from other Tanytarsus species by the following combination of characters: Hypopygium with 2-6 median setae on anal tergite; anal point somewhat triangular with spines between well developed anal crests; superior volsella well developed with concave median margin; digitus large, Sformed when squeezed, baring one seta at half length; median volsella, small, with three pectinate lamellae that are almost only visible if the hypopygium is squeezed. Pupal thoracic horns long, slender with small chaetae evenly distributed on apical halves, medium long cephalic tubercles with longer frontal setae; frontal apotome and anterodorsal part of cephalothorax granulated; pedicel sheath tubercles small or absent; hook row c. $2 / 3$ width of tergite II; spine patches of tergites III, IV, V and VI relatively small, elongate on anterior parts of tergites; lateral taeniae on segment $\mathrm{V}$ through VIII. Larva with fine haired premento-hypopharyngeal complex; dorsal tooth of mandible well developed; Middle tooth of mentum pale with one large notch on either side; ventromental plate with very weak striation; six anal setae on procercus.

\section{Description}

Male imago ( $\mathrm{n}=7-10)$. - Total length 1.5-2.1, 1.9 $\mathrm{mm}$. Wing length $0.95-1.34,1.13 \mathrm{~mm}$. Total length/wing length 1.60-1.81, 1.72. Coloration. Cleared specimens with head light brown, darker brown pedicel, apodemes and eyes; thorax with dark brown patches anteriorly and laterally on scutum, basally on postnotum and on preepisternum; legs light brown; abdomen pale yellowish.

Head. - Antenna normally developed, AR 0.50$0.81,0.62$. Thirteenth flagellomere 226-355, $301 \mu \mathrm{m}$ long. Longest antennal seta c. $310-450 \mu \mathrm{m}$ long. Distance between eyes 113-149, $132 \mu \mathrm{m}$ small frontal tubercles, c. $4 \mu \mathrm{m}$ long. Temporal bristles $6-10$; including 1-3 inner verticals, 2-5 outer verticals and 2-4 postorbitals. Clypeus semicircular, 43-55 $\mu \mathrm{m}$ long with 10-14 setae. Tentorium 82-126, $102 \mu \mathrm{m}$ long,
16-29 $\mu \mathrm{m}$ wide at sieve pore. Stipes 74-120, $104 \mu \mathrm{m}$ long, 8-12 $\mu \mathrm{m}$ wide. Cibarial pump 31-58 $\mu \mathrm{m}$ wide. Lengths of palp segments (in $\mu \mathrm{m}$ ): 20-27, 24; 26-32, 28; 70-101, 88; 78-109, 90; 137-168, 153.

Thorax. - Dorsocentrals 4-8, acrostichals 10-18, prealars 1, scutellars 4. Halteres with 4-6 setae.

Wing. - VR 1.12-1.40, 1.23. Brachiolum with 1 seta, $\mathrm{Sc}$ bare, $\mathrm{R}$ with $13-18$ setae, $\mathrm{R}_{1}$ with $13-17, \mathrm{R}_{4+5}$ with 21-28, $\mathrm{M}_{1+2}$ with 21-38, $\mathrm{M}_{3+4}$ with 20-29, Cu with 10-27, $\mathrm{Cu}_{1}$ with $12-19$, PCU with $19-32$ and An with 12-24 setae. Cell $\mathrm{m}$ bare, $\mathrm{r}_{4+5}$ with 66-140 setae, $\mathrm{m}_{1+2}$ with 94-200 setae including on false vein, $\mathrm{m}_{3+4}$ with 28-75, cu with 10-84 and an with 3-24.

Legs. - Spur on front tibia c. $25 \mu \mathrm{m}$ long including scale. Spurs of middle tibia $24-30 \mu \mathrm{m}$ long including 12-16 $\mu \mathrm{m}$ long comb and 18-27 $\mu \mathrm{m}$ long including $12-16 \mu \mathrm{m}$ long comb; of hind tibia $29-43 \mu \mathrm{m}$ long including 12-16 $\mu \mathrm{m}$ long comb and 21-32 $\mu \mathrm{m}$ long including $12-16 \mu \mathrm{m}$ long comb. Middle tibiae with $0-4$ sensilla chaeticae. Lengths and proportions of legs see table 11.

Hypopygium (figs. 48, 49). - Tergite IX 58-94, 76 $\mu \mathrm{m}$ long with 2-6 median and 10-12 apical setae; apical margin without shoulders; lateral teeth not visible; microtrichia absent in small areas on either side of base of anal point. Anal point somewhat triangular, 25-36 $\mu \mathrm{m}$ long, $10-19 \mu \mathrm{m}$ wide at base and 4-5 $\mu \mathrm{m}$ wide at apex. Anal point with 2-6 spines between well developed anal crests. Broad anal tergite bands curved anally, ending far from anal point. Transverse sternapodeme 29-41, $37 \mu \mathrm{m}$ long, phallapodeme 70-98, $82 \mu \mathrm{m}$ long. Gonocoxite 72-111, $99 \mu \mathrm{m}$ long, gonostylus $60-100,84 \mu \mathrm{m}$ long. Superior volsella (fig. 50) with concave median margin; bearing 2-3 small dorsal setae; $2-3$ small lateral setae and 2 median setae; dorsolateral microtrichia absent; digitus long, reaching well beyond median margin of superior volsella, $S$ - shaped with 1 seta placed on small tubercle at half length. Median volsella (fig. 51) 4-6 $\mu \mathrm{m}$ long with 3, 10-14 $\mu \mathrm{m}$ long, pectinate lamellae. Inferior volsella relatively straight, 43-74, $64 \mu \mathrm{m}$ long. HR 1.04-1.24, 1.17; HV 2.07-2.86, 2.36 .

Table 11. T. trifidus. Lengths (in $\mu \mathrm{m}$ ) and proportions of legs.

$\mathrm{fe}$

\begin{tabular}{lll}
\hline $\mathrm{p}_{1}$ & $449-585,515$ & $203-255,237$ \\
$\mathrm{p}_{2}$ & $433-552,501$ & $351-488,466$ \\
$\mathrm{p}_{3}$ & $437-575,517$ & $452-633,533$ \\
\hline
\end{tabular}

$\mathrm{ta}_{1}$

$655-866,730$

$199-313,258$

$292-410,341$ $\mathrm{ta}_{2}$

$296-397,346$

90-145, 111

$176-233,197$

SV $\mathrm{ta}_{3}$

250-320, 283

$55-97,74$

148-203, 175

BR

\begin{tabular}{lllll}
\hline $\mathrm{p}_{1}$ & $2.88-3.41,3.16$ & $1.52-1.72,1.60$ & $0.97-1.06,1.02$ & $2.7-3.5,3.1$ \\
$\mathrm{p}_{2}$ & $0.54-0.64,0.60$ & $3.88-4.57,4.25$ & $3.32-4.08,3.70$ & $3.6-6.3,5.1$ \\
$\mathrm{p}_{3}$ & $0.65-0.70,0.68$ & $2.42-2.55,2.50$ & $2.81-3.04,2.93$ & $5.0-5.8,5.4$ \\
\hline
\end{tabular}


Pupa $(\mathrm{n}=10)$. - Total length 2.2-2.8, $2.5 \mathrm{~mm}$. Coloration light brown.

Cephalothorax (fig. 55, 68). - Length of frontal setae 51-98, $74 \mu \mathrm{m}$, cephalic tubercles relative small, conical (fig. 55), 16-27, $19 \mu \mathrm{m}$ long. Frontal apotome (fig. 55) with patches of granulation anterior of cephalic tubercles. Pedicel sheath tubercle small or absent. Thoracic horn slender, 449-566, $502 \mu \mathrm{m}$ long, 12-27 $\mu \mathrm{m}$ wide, with small, $2-5 \mu \mathrm{m}$ long, chaetae, evenly distributed on apical half. Three precorneals in a triangular pattern, one precorneal strong, 60-103, $80 \mu \mathrm{m}$ long, the other two precorneals 29-48, $43 \mu \mathrm{m}$ long; antepronotals 3: median 38-47, $55 \mu \mathrm{m}$ long, laterals 2460, 40 and 7-12 um long; 2 pairs of dorsocentrals with 1 thin and 1 thick seta in each pair, anterior pair 31-50, 42 (thin) and 19-34, 27 (thick) $\mu \mathrm{m}$ long, posterior pair $36-65,51$ (thin) and 36-46, 40 (thick) $\mu \mathrm{m}$ long. Fine granulation dorsal of anterior dorsocentrals. Nose of wing sheath well developed c. $15 \mu \mathrm{m}$ long.

Abdomen (figs. 74, 76). - Shagreen on tergite (T) II as in fig. 76; pedes spurii B on TII weak; hook row 132-168, $148 \mu \mathrm{m}$ long, c. $2 / 3$ width of TII; spines of TIII-VI 2-10 $\mu \mathrm{m}$ long, in anterior, small, elongated patches; segment I with $2 \mathrm{D}$ and $2 \mathrm{~L}$ setae, segment II with $2 \mathrm{D}, 2 \mathrm{~V}$ and 3, 12-24 $\mu \mathrm{m}$ long $\mathrm{L}$ setae; segment III with $5 \mathrm{D}, 2 \mathrm{~V}$ and 3, 12-24 $\mu \mathrm{m}$ long $\mathrm{L}$ setae; segment IV with $5 \mathrm{D}, 3 \mathrm{~V}$ and 3, 12-24 $\mu \mathrm{m}$ long $\mathrm{L}$ setae; segment $\mathrm{V}$ with $5 \mathrm{D}, 3 \mathrm{~V}$ and 3, c. $100 \mu \mathrm{m}$ long lateral taeniae; segment VI with 5 D, $4 \mathrm{~V}$ and 3, c. $100 \mu \mathrm{m}$ long lateral taeniae; segment VII with $4 \mathrm{D}, 4 \mathrm{~V}$ and 4 , c. 100-140 $\mu \mathrm{m}$ long lateral taeniae; segment VIII with $1 \mathrm{D}, 1 \mathrm{~V}$ and 5 , c. $100-150 \mu \mathrm{m}$ long lateral taeniae of which the third seta is placed more medially than the other four; anal lobe with 2 dorsal, c. $150 \mu \mathrm{m}$ long taeniae, anal fringe with 14-17, 240-350, $330 \mu \mathrm{m}$ long taeniae; posterior lateral comb of segment VIII (fig. 84) $12-19 \mu \mathrm{m}$ wide with 7-9 apical teeth.

Larva $(n=1)$. - Length of head capsule $269 \mu \mathrm{m}$, width $199 \mu \mathrm{m}$, length/width $=1.35$.

Head. - Antenna unfortunately missing from the slide. Antennal pedestal $53 \mu \mathrm{m}$ long. Mandible (fig. 94) $98 \mu \mathrm{m}$ long with 3 ventral inner teeth, and 1 dorsal apical tooth present; two outer mandibular setae present; seta subdentalis thick, c. $36 \mu \mathrm{m}$ long and curved, reaching well beyond apex of dorsal tooth; seta interna well developed with 4 main branches. Mentum (fig. 101) $55 \mu \mathrm{m}$ wide with 11 teeth; median tooth pale with large lateral notches; ventromental plate, $84 \mu \mathrm{m}$ wide, with very weak striation; premento-hypopharyngeal consisting of a hairlike comb (fig. 101). S3 simple, other labral structures not visible.

Body. - Anterior and posterior parapods with simple claws; procercus with 6 anal setae: 2 short, c. 120 $\mu \mathrm{m}$ long and 4 long c. $240 \mu \mathrm{m}$ long.

\section{Remarks}

Diagnosis and description of larva is based on parts of one exuvia with missing antennae, and is therefore incomplete. Based on adult male characters, Tanytarsus trifidus keys out to the chinyensis-group (Cranston et al. 1989), and the species fulfils all the requirements given by Reiss \& Fittkau (1971) in the group diagnosis. After examining material of the species Tanytarsus brundini, T. chinyensis, T. cretensis and T. curticornis located in the Zoologische Staatssammlung München, it is clear that the presence of one seta on the digitus itself and two setae on the median margin of superior volsella might be diagnostic characters for the $T$. chinyensis species group. Males of $T$. trifidus separates from the other species in the $T$. chinyensisgroup by having a low AR (0.60), a strongly S-shaped digitus with one seta at half length and a small median volsella with three pectinate lamellae. T. trifidus keys to the same group based on pupal morphology (Pinder \& Reiss 1986). Unfortunately, the number of lateral taeniae on segment VIII is used by Pinder $\&$ Reiss (1986) as a separating character in the key to Tanytarsus species groups. This characters has shown to be intraspecifically variable, and the number of lateral taeniae on segment VIII can even be different on either side of the same specimen! After examining associated material of $T$. brundini, $T$. chinyensis, $T$. cretensis, $T$. curticornis and $T$. trifidus, the following combination of characters seems to be diagnostic for pupae of the $T$. chinyensis-group: Cephalic tubercles small; chaetae small, evenly distributed on at least apical $1 / 2$ of thoracic horn; tergite spines short, in elongated anterior spine patches on segments III-VI. T. trifidus pupae can be separated from the other species in the chinyensis-group by the following combination of characters: granulated frontal apotome, slender thoracic horn with very short chaetae $(2-5 \mu \mathrm{m})$ on apical $1 / 2$, the small amount of taeniae in anal fringe $(<17)$ and the lateral taeniae on segment V-VIII. According to Hofmann (1971), larvae with a very long tapered spur distally on the antennal pedestal characterizes the larvae of the $T$. chinyensis species group. No such spurs are recognizable on the larval exuvia available for $T$. trifidus, but the spurs could have been lost together with the antennae.

In Opi Lake, T. trifidus was common in the whole sampled depth range (0-1 m), and found on muddy substrate (Hare \& Carter 1987).

\section{Tanytarsus zariae Freeman}

Tanytarsus zariae Freeman, 1958: 342. Holotype ô (BNMH) Nigeria, Zaria, 11.XI.1956, leg. B. McMillan, paratypes $10^{\circ}$ as holotype, $10^{\pi}$ (BNMH) Ghana, Red Volta, Nangodi, 8.X.1954, leg. G. Crisp [examined]. 


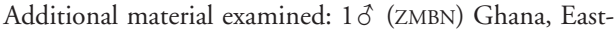
ern Region, Boti Falls, light trap, 14.XI.1994, leg. NUFUproject; 20 (ZMBN) Burkina Faso, Lanviera, 26.VI.1973,

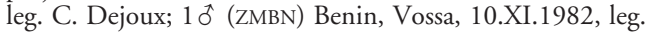
C. Dejoux.

\section{Diagnosis}

The species differs from other Tanytarsus species by the following combination of characters: frontal tubercles well developed; AR > 1.1; wings hairy with c. 10 setae in cell m; hypopygium with 3-6 median setae on anal tergite, anal point with apical tubercle, 4-6 small spines and microtrichia between well developed anal crests; superior volsella kidney- shaped with 5-6 long, dorsal setae, microtrichia absent; digitus long, usually reaching well beyond posteromedian margin of superior volsella; median volsella medium large with several foliate and simple lamellae; gonostylus with widest width at $1 / 3$ length.

\section{Description}

Male imago ( $\mathrm{n}=4$ unless otherwise stated). - Total length 2.4-3.0, $2.7 \mathrm{~mm}$. Wing length 1.39-1.68, 1.51 (3) mm. Total length/wing length 1.7-2.0, 1.8. Coloration. Cleared specimens light greenish with light brownish eyes, antennae, stripes anteriorly and laterally on scutum and on postnotum.

Head. - Antenna normally developed with AR 1.12$1.22,1.19$ (3). Ultimate flagellomere 523-572, 549 (3) $\mu \mathrm{m}$ long. Longest antennal seta c. $500 \mu \mathrm{m}$ long. Distance between eyes c. 145-168, $162 \mu \mathrm{m}$. Frontal tubercles well developed, c. $18 \mu \mathrm{m}$ long. Temporal bristles 9- 11; including 2-3 inner verticals, 3-4 outer verticals and 3-4 postorbitals. Clypeus semicircular, 64-94 (2) $\mu \mathrm{m}$ long with 11-17 setae. Tentorium 139155, $147 \mu \mathrm{m}$ long, 32-36, $34 \mu \mathrm{m}$ wide at sieve pore. Stipes 139-155, 146 (3) $\mu \mathrm{m}$ long, 10-13 (3) $\mu \mathrm{m}$ wide. Cibarial pump 55-68, $58 \mu \mathrm{m}$ wide. Lengths of palpomeres (in $\mu \mathrm{m}$ ): 32-39; 32-42; 94-168, 126; 107 149, 123; 200-284, 229.

Thorax. - Scutal tubercle absent. Dorsocentrals 69, acrostichals 14-18, prealars 1, scutellars 5-6, halteres with 6-9 setae.
Wing. - VR 1.22-1.28, 1.25. Sc bare, R with 21-32, 27 setae, $R_{1}$ with 28-39, 34; $R_{4+5}$ with 57-72, 64 setae; $\mathrm{M}$ bare; $\mathrm{M}_{1+2}$ with 54-68, 62 (3) setae; $\mathrm{M}_{3+4}$ with 34 41, 37 (3) setae; $\mathrm{Cu}$ with 17-21, 19; $\mathrm{Cu}_{1}$ with 21-24, 23; PCu with 22-29, 25 and An with 26-31, 28 setae. Cell $\mathrm{m}$ with c. 10 setae, $\mathrm{r}_{4+5}$ with c. $150-200$ setae, $\mathrm{m}_{1+2}$ with c. 250 including on false vein, $m_{3+4}$ with c. 80 and $\mathrm{cu}+$ an with c. 100 setae.

Legs. - Spur on front tibia 36-42 $\mu \mathrm{m}$ long including scale. Spurs of middle tibia $32-45 \mu \mathrm{m}$ long including 16-23 $\mu \mathrm{m}$ long comb; of hind tibia $42-52 \mu \mathrm{m}$ long including 19-25 $\mu \mathrm{m}$ long comb. Middle tibia with 6-7 sensilla chaeticae. Lengths and proportions of legs see table 12 .

Hypopygium (fig. 43). - Tergite IX 109-127, 120 $\mu \mathrm{m}$ long with 4-6 median setae, 20-24 apical setae; apical margin without lateral shoulders, but seems divided into three lappets; microtrichia present between spines of anal point. Anal point 51-66, $58 \mu \mathrm{m}$ long, 21-27, $24 \mu \mathrm{m}$ wide at base and 2-4 $\mu \mathrm{m}$ wide at apex. Anal point with 4-6 spines between well developed anal crests. Anal tergite bands short, caudally curved. Transverse sternapodeme 41-57, $50 \mu \mathrm{m}$ long; phallapodeme 107-123, $115 \mu \mathrm{m}$ long. Gonocoxite 133$148,139 \mu \mathrm{m}$ long with three inner setae, gonostylus with widest width at 1/3 length, 123-131, $127 \mu \mathrm{m}$ long. Superior volsella (fig. 44) oval with parallel edges, 4-5 long, dorsal setae, microtrichia absent; digitus long, reaching beyond posteromedian margin of superior volsella. Median volsella (fig. 44) 51-66, 57 $\mu \mathrm{m}$ long including 3-4 falciform and 13-14, 25-35 $\mu \mathrm{m}$ long, simple lamellae. Inferior volsella thick, relatively straight, 88-98, $94 \mu \mathrm{m}$ long, with strong apical setae. HR 1.03-1.13, 1.09; HV 2.17-2.27, 2.21 (3).

\section{Remarks}

Based on the adult male morphology, Tanytarsus zariae keys to the T. eminulus species group (Cranston et al. 1989), and fit the group diagnosis except for the narrow apical tubercle of the anal point (Reiss \& Fittkau 1971).

Table 12. T. zariae. Lengths (in $\mu \mathrm{m}$ ) and proportions of legs.

fe

ti

$\mathrm{ta}_{1}$

$\mathrm{ta}_{2}$

ta

$\operatorname{ta}_{4}$

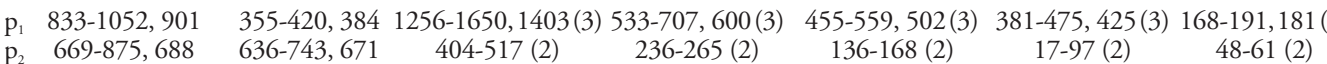

$\mathrm{p}_{3}$ 795-930, $845(3) \quad 789-930,848(3) \quad 559-682,606(3) \quad 336-404,360(3) \quad 294-362,323(3) \quad 178-226,201(3) \quad 87-97,93(3)$

\begin{tabular}{ccccc}
\hline & LR & BV & SV & BR \\
\hline $\mathrm{p}_{1}$ & $3.35-3.84,3.53(3)$ & $1.55-1.62,1.59(3)$ & $0.89-0.97,0.94(3)$ & $2.7-3.2,3.0(3)$ \\
$\mathrm{p}_{2}$ & $0.63(2)$ & $3.55-3.61(2)$ & $3.13-3.35(2)$ & $4.4-5.8(2)$ \\
$\mathrm{p}_{3}$ & $0.70-0.73,0.72(3)$ & $3.34-2.39,2.36(3)$ & $2,73-2.83,2.80(3)$ & $4.1-6.7,5.4(3)$ \\
\hline
\end{tabular}




\section{DisCUSSION}

As the systematic discussion after each species description indicates, Afrotropical Tanytarsus species do not fit well in the European species groups erected by Reiss \& Fittkau (1971) (see also Ekrem 1999), and most of the group diagnoses have to be emended quite a bit to fit certain species. It is no doubt that a world revision including phylogenetic analyses of the genus Tanytarsus is required to test the existing and create possible new species groups.

\section{SPECIES LISTS AND KEYS}

\section{Afrotropical Tanytarsus species and their distribution}

T. ankasaensis sp. $\mathrm{n}$. Ghana

T. aterrimus Freeman, 1954. South Africa, Zimbabwe (Freeman 1958, Freeman \& Cranston 1980, Harrison 1997)

T. atomarius Kieffer, 1918. South Africa, ? Seychelles (Freeman 1958)

T. atrocinctus Goetghebuer, 1936. Democratic Republic of Congo (Freeman 1958)

T. balteatus Freeman, 1955. (Misspelled balateatus in Freeman \& Cranston 1980) Sudan, Nigeria, Uganda, Democratic Republic of Congo, South Africa, Tchad, Central African Republic, India, Nepal (Freeman 1958, Dejoux 1968c, 1976a, Reiss 1971, Datta et al. 1992)

T. bifurcus Freeman, 1958. Burkina Faso, Tchad, Mali, Nigeria, Ghana (Dejoux 1968a, 1968c, 1974, Freeman \& Cranston 1980)

T. congus Lehmann, 1981. Democratic Republic of Congo (Lehmann 1981), Ghana, Senegal (new records)

T. elisabethae sp. n. Nigeria

T. flexistilus Freeman, 1958. Burkina Faso, Tchad, Nigeria (Dejoux 1968a, 1968c, Hare \& Carter 1987), Ghana (new record)

T. formosanus Kieffer, 1912. AFRICA: Central African Republic, Tchad, Nigeria, Ghana, Togo, Benin, Sudan, Kenya, Democratic Republic of Congo, Uganda, Burkina Faso, South Africa (Freeman 1957a, 1958, Dejoux 1968a, 1968b, 1968c, 1976a, 1976b, 1984 Petr 1972, Hare \& Carter 1987, Harrison 1987, Verschuren 1997). WEST PALAEARCTIC: South France, South Spain, Middle East (Goetghebuer 1934, Reiss \& Fittkau 1971, Langton 1991, Laville \& Tourenq 1968, Laville \& Reiss 1992). SOUTH ASIA: Taiwan, Hubei Province, China, India, Sumatra, Thailand (Kieffer 1923a, Hashimoto et al. 1981, Chaudhuri et al. 1984, Kikuchi \& Sasa 1990, Chaudhuri et al. 1992, Wang \& Zheng 1992, Mazumdar et al. 1998)

T. harei sp. n. Nigeria, Senegal, Côte d'Ivoire
T. kakumensis Ekrem, 1999. Ghana

T. luctuosus Freeman, 1958. South Africa, Zimbabwe, Democratic Republic of Congo, Tanzania (Lehmann 1979, Freeman \& Cranston 1980, Stur \& Ekrem 2000)

T. mcmillani Freeman, 1958. Senegal, Nigeria, Tchad, Saudi Arabia, Cameroun, India (Dejoux 1974, Freeman \& Cranston 1980, Cranston \& Judd 1989, Datta et al. 1992)

T. minutipalpus Ekrem \& Harrison, 1999. Ethiopia, Kenya, Tanzania

T. nocticola Kieffer, 1911. Egypt, Sudan, Democratic Republic of Congo (Freeman 1958, Freeman \& Cranston 1980)

T. pallidissimus Kieffer, 1911. Seychelles (Freeman \& Cranston 1980)

T. pallidulus Freeman, 1954. South Africa, Mozambique, Nigeria, Zimbabwe, Democratic Republic of Congo, Saudi Arabia (Freeman \& Cranston 1980, Cranston \& Judd 1989)

T. pseudocongus Ekrem, 1999. Ghana, Nigeria (new record)

T. saetheri Ekrem, 1999. Ghana, Côte d'Ivoire (new record)

T. spadiceonotatus Freeman, 1958. Nigeria, Tchad, Zimbabwe, Senegal, Burkina Faso (Dejoux 1968a, 1968c, 1974, 1976a, 1977, Freeman \& Cranston 1980, Hare \& Carter 1987)

T. spiesi Ekrem, 1999. Ghana

T. superpenicillatus Ekrem, 1999. Ghana

T. tossai Ekrem, 1999. Ghana, Nigeria (new record)

T. trifidus Freeman, 1958. Nigeria, Madagascar, Ghana, Burkina Faso, Saudi Arabia, Central African Republic, Senegal, Mali, Tchad (Dejoux 1968a, 1968c, 1974, 1976a, Hare \& Carter 1987, Cranston \& Judd 1989)

T. usambarae Stur \& Ekrem, 2000. Tanzania

T. zariae Freeman, 1958. Nigeria, Tchad, Ghana, Senegal, Benin (Dejoux 1968a, 1968c, 1974, 1984)

\section{Tanytarsus species of Ghana}

T. ankasaensis sp. n. (Western region: Ankasa Game Production Reserve; Great Accra region: Accra)

T. bifurcus Freeman, 1958. (Northern region: Sogo)

T. congus Lehmann, 1981. (Western region: Ankasa Game Production Reserve; Eastern region: Subri stream; Central region: Kakum Forest Reserve)

T. flexistilus Freeman, 1958. (Northern region: at Sogo river; Volta region: Kpong)

T. formosanus Kieffer, 1912. (Volta region: Kpong)

T. kakumensis Ekrem, 1999. (Central region: Kakum Forest Reserve)

T. pseudocongus Ekrem, 1999. (Western region: Ankasa Game Production Reserve; Volta Region: Agumatsa waterfalls) 
T. saetheri Ekrem, 1999. (Western region: Ankasa Game Production Reserve)

T. spiesi Ekrem, 1999. (Central Region, Kakum Forest Reserve)

T. superpenicillatus Ekrem, 1999. (Eastern region: Bothi waterfalls; Eastern region: Subri stream)

T. tossai Ekrem, 1999. (Western region: Ankasa Game Production Reserve; Volta region: Agumatsa waterfalls)

T. trifidus Freeman, 1958. (Central region: Kakum Forest Reserve; Western region: Ankasa Game Production Reserve)

T. zariae Freeman, 1958. (Eastern region: Bothi waterfalls)

\section{Key to Afrotropical Tanytarsus males}

Tanytarsus africanus Kieffer, 1913, T. misorus Kieffer, 1913, T. tropicalis Kieffer, 1913, T. brachyopsis Kieffer, 1913, T. apicalis Kieffer, 1913, T. nilobius Kieffer, $1923 \mathrm{~b}$ and Hexatanytarsus albiradix Kieffer, 1923b are all regarded as doubtful species by Freeman (1958).

1. Anal point without spines or with one pair of lamellae between crests.

- Anal point with stout spines between anal crests (figs. 1, 3, 5, 7)

2. Digitus long, clearly extending beyond inner margin of superior volsella ...................................

- Digitus not extending beyond inner margin of superior volsella

3. Superior volsella almost square with convex inner margin, median volsella very long with setae in a fan-like arrangement reaching apex of inferior volsella (Freeman 1958: 334, fig. 10b)

T. balteatus

- Superior volsella of different shape with apical, median directed point, median volsella not reaching apex of inferior volsella..................................

4. Anal point bifid, with one pair of lamellae between crests (Freeman 1958: 334, fig. 10g)

- Anal point simple.

T. bifurcus

5. Median volsella broad and knob like, inferior volsella short, as long or only a little longer than apex of gonocoxite (Freeman 1958: 334, fig. 10f, misspelled 'noticolor') ....................... T. nocticola

- Both median and inferior volsella longer than above.....

6. Superior volsella large with an obvious projection on lateral margin, digitus with broad base, inferior volsella reaching to about $1 / 2$ length of gonostylus (Freeman 1958, p. 334, fig. 10h).

T. atomarius

- Superior volsella medium sized, digitus with narrow base, inferior volsella reaching to about $1 / 3$ length of gonostylus (Freeman 1958: 334, fig. 10i) T. pallidissimus

7. Superior volsella roughly oval, inferior volsella with parallel margins (Freeman 1958: 334, fig. 10c) T. pallidulus

- Superior volsella L-shaped, with broad base, inferior volsella club shaped (Freeman 1958: 334, fig. 10) T. atrocinctus

8. Digitus of superior volsella with one seta (fig. 6) .

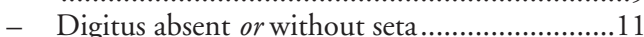

9. Median volsella with three pectinate lamellae, digitus S-shaped (figs. 50, 51) .............T. trifidus

- Median volsella with falciform and pectinate lamellae, digitus straight with swollen apex ....10

10. Seta on digitus placed basally, AR less than 0.45 , $\mathrm{LR}_{1}$ less than 2.90 (figs. 30, 31) ...T. pseudocongus

- Seta on digitus placed at $1 / 2$ length, AR larger than 0.6, $\mathrm{LR}_{1}$ larger than 3.0 (figs. 5, 6) ........T. congus

11. Superior volsella roughly square, anal tergite bands of Y-type ending between crests of anal point (fig. 3) .................................... T. aterrimus

- Superior volsella elongate or with several pointy edges, anal tergite bands never of Y-type ..........12

12. Digitus clearly overreaching median margin or apex of superior volsella (figs. 11, 32, 37)........13

- Digitus never much longer than apex of superior

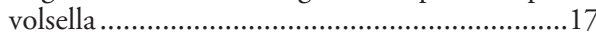

13. Crests of anal point long and parallel sided, superior volsella elongate. .14

- Crests of anal point short or $\mathrm{V}$-shaped, superior volsella round or triangular (figs. 32, 37) ..........16

14. Superior volsella with deep median invagination (figs. 11, 13) T. flexistilus

- Superior volsella with fairly straight median mar-

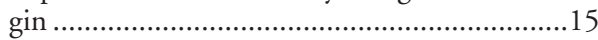

15. Microtrichia present between spines of anal point, tip of anal point with small tubercle (fig. 43) ....................................................... T. zariae

- Microtrichia absent between spines of anal point, tip without small tubercle ..................................21

16. Long V-shaped anal crests, superior volsella with dorsolateral microtrichia, digitus with median microtrichia (figs. 32, 33) .................... T. saetheri

- Anal crests short, no microtrichia on superior volsella or digitus (fig. 37) ..................... T. spiesi

17. Palpomeres normally developed and digitus absent or minute and median volsella long, always reaching past apex of superior volsella not counting its lamellae (figs. 19, 39) ............................18

- Palpomeres reduced or digitus easily distinguishable or median volsella (without lamellae) not reaching beyond apex of superior volsella (fig. 17)

18. Gonostyli very short, HR > 1.6 (fig. 19) T. kakumensis

- Gonostyli not reduced . .19 
19. Lamellae of median volsella reaching tip of gonostylus (fig. 39) ..............T. superpenicillatus

- Lamellae of median volsella long and setiform but never reaching apex of gonostylus (fig. 45) ...

20. Scutal tubercle present, small posteromedian tubercle on superior volsella (figs. $21,22,23$ ) .........

T. luctuosus

- Scutal tubercle absent, small posterolateral tubercle on superior volsella (figs. 45, 46)

T. usambarae

21. Large microtrichia-free area at base of anal point (figs. 14, 17)

- Microtrichia present at anal point base (fig. 25) ..

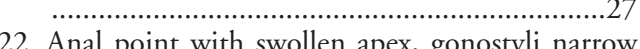
and parallel sided, lamellae of median volsellae bent caudally (fig. 41) .............................. T. tossai

- Anal point with normal, rounded apex, gonostyli not narrow or parallel sided, lamellae of median volsellae not bent caudally (figs. 7,27 )............23

23. Palpomeres reduced, median setae absent from anal tergite (fig. 27) ................. T. minutipalpus

- Palpomeres normal, 2 or more median setae present on anal tergite.

...24

24. Scutal tubercle well developed. Anal point long and thin with small spines between relatively low anal crests (figs. 7,10 ) T. elisabethae

- Scutal tubercle absent. Anal point wide with large spines between well developed anal crests (figs. 1, $14,17)$

25. Small midges with wing length less than $1.2 \mathrm{~mm}$, $\mathrm{LR}_{1}$ larger than 3.3 ......................... T. ankasaensis

- Medium large midges with wing length larger than $1.3 \mathrm{~mm}, \mathrm{LR}_{1}$ less than $2.8 \ldots \ldots \ldots \ldots \ldots \ldots \ldots \ldots . . .26$

26. Digitus and dorsolateral microtrichia on superior volsella present (figs. 14, 15, 16) ...T. formosanus

- Digitus and dorsolateral microtrichia on superior volsella absent (figs. 17, 18) .................... T. harei

27. Anal tergite triangular, small spines between anal crests, veins $\mathrm{Cu}, \mathrm{Cu}_{1}, \mathrm{PCu}$ and An hairy (fig. 25) . T. mcmillani

- Anal tergite roughly quadrate, large spines between anal crests, veins $\mathrm{Cu}, \mathrm{Cu}_{1}, \mathrm{PCu}$ and $\mathrm{An}$ all bare (fig. 35) .............................T. spadiceonotatus

Key to known Afrotropical Tanytarsus pupae

1. Antepronotum with large sausage- shaped tubercle (fig. 64) ....................................... T. flexistilus

- Antepronotum without such large tubercle .......2

2. One pair of anterior spinule patches in addition to shagreen present on tergite II (fig. 75)

T. luctuosus

- Only shagreen present on tergite II ......................

3. Thoracic horn bare, cephalic tubercles as long as frontal setae (figs. 56, 62) .........T. minutipalpus
- Thoracic horn with chaetae, cephalic tubercles shorter than frontal setae...................................... 4

4. Chaetae of thoracic horn small and evenly distributed on distal half, posterolateral comb less than $25 \mu \mathrm{m}$ wide (figs. 68, 80)............. T. trifidus

- Chaetae of thoracic horn in one row, posterolateral comb more than $25 \mu \mathrm{m}$ wide (figs. 63, 66, $82,84)$

5. Thoracic horn with chaetae more than two times longer than width of horn. Less than 15 taeniae in anal fringe (figs. 60, 79).......T. spadiceonotatus

- Chaetae of thoracic horn about as long as width of horn. More than 16 taeniae in anal fringe (figs. $58,59,78)$

6. Thoracic horn long and thin, row of chaetae $1 / 3$ length of horn. Armament of tergites III-VI of equally short spinules (figs. 58, 70)...T. elisabethae

- Thoracic horn wider, row of chaetae $2 / 3$ length of horn. Spines on tergites III-IV much longer than spinules of tergites V-VI (figs. 59, 69, 77).

T. formosanus

Key to known Afrotropical Tanytarsus larvae

1. Only one dorsal tooth present on mandible (fig. $94,97,98)$

- Two or more dorsal teeth present on mandible...

2. Small species, antennal pedestal about $55 \mu \mathrm{m}$ long, mentum about $55 \mu \mathrm{m}$ wide, ventromental plates with very weak striation (fig. 101) .. T. trifidus

- Larger species, antennal pedestal longer than 62 $\mu \mathrm{m}$, mentum wider than $61 \mu \mathrm{m}$, ventromental plates with obvious striation (figs. 100, 102).....3

3. Antenna with Lauterborn organs barely reaching beyond antennal segment 5 (fig. 88)

T. elisabethae

- Antenna with Lauterborn organs reaching far beyond antennal segment 5 (fig. 87)

T. spadiceonotatus

4. Styli of Lauterborn organs about the length of antennal segment 3, three dorsal teeth, proximal tooth is a large and rectangular (fig. 95).

T. minutipalpus

- Styli of Lauterborn organs longer than antennal segment 3, mandible with two dorsal teeth ........5

5. Antenna including Lauterborn organs about the same length or longer than head capsule, Lauterborn organs with styli more than 3 times the length of antennal segment 3-5 combined (fig. 86) .................................................... T. flexistilus

- Antenna including Lauterborn organs not as long as length of head capsule, Lauterborn organs with styli barely reaching beyond tip of antenna (Dejoux 168: 450, fig. 6) .T. formosanus 


\section{ACKNOWLEDGEMENTS}

I would like to thank Peter Cranston at UC Davis, Ole A. Sæther, Trond Andersen and Elisabeth Stur at the Museum of Zoology, University of Bergen, Norway for critically reading different versions of the manuscript; Landis Hare, INRS Quebec, Canada, John Chainey, the Natural History Museum, London, England, P. K. Chaudhuri, University of Burdwan, India and Frank Menzel, DEI, Eberswalde, Germany, for generously sending me type material. Thanks also to Gerhard Haszprunar and the late Friedrich Reiss both at ZSM, Munich, Germany for help and advice during my stay in Munich, Joe Amakye, Institute of Aquatic Biology, Achimota for all help in Ghana and Ghana Wildlife Department for permission to collect in the nature reserves. Field work in Ghana was supported by the Norwegian Universities Committee for Development, Research and Education (NUFU).

\section{REFERENCES}

Chaudhuri, P. K., D. K. Guha \& M. Gosh, 1984. Tanytarsini (Diptera: Chironomidae) from India. - Oriental Insects 18: 31-41.

Chaudhuri, P. K., S. K. Nandi \& M. Ghosh, 1988. Taxonomy and biology of Tanytarsus aculeus n. sp. (Diptera: Chironomidae) from India. - Acta Hydrobiologica 30: 239-251.

Chaudhuri, P. K., A. Ali \& A. Majumdar, 1992. Life stages of Tanytarsus van der Wulp with description of a new species from India (Diptera, Chironomidae). - Deutsche entomologische Zeitschrift 39: 381-396.

Cranston, P. S., M. E. Dillon, L. C. V. Pinder \& F. Reiss, 1989. The adult males of Chironominae (Diptera, Chironomidae) of the Holarctic region. Keys and diagnoses. - In Wiederholm, T. (ed.) Chironomidae of the Holarctic region. Keys and diagnoses. Part 3. Adult males. - Entomologica scandinavica Supplement 34: 353-502, pls.

Cranston, P. S. \& D. D. Judd, 1989. Diptera: Fam. Chironomidae of the Arabian peninsula. - Fauna of Saudi Arabia 10: 236-289.

Datta, T., A. Majumdar \& P. K. Chaudhuri, 1992. Taxonomic studies on Tanytarsus v.d. Wulp (Diptera: Chironomidae) in India. - Oriental Insects 26: 39-66.

Dejoux, C., 1968a. Contribution a l'étude des insectes aquatiques du Tchad. - Cahier Office de la Recherche Scientifique et Technique Outre-mer, série Hydrobiologie 2: $51-78$.

Dejoux, C., 1968b. Contribution à l'étude des premiers états des Chironomides du Tchad (première note). - Hydrobiologia 31: 449-464.

Dejoux, C., 1968c. Le Lac Tchad et les Chironomides de sa partie est. - Annales Zoologici Fennici 5: 27-32.

Dejoux, C., 1974. Contribution à la connaissance des Chironomides de l'Afrique de l'Ouest. - Entomologisk Tidskrift Supplement 95: 71-83.

Dejoux, C., 1976a. Données faunistiques nouvelles concernant les Chironomides (Diptères, Nématocères) de la Région Éthiopienne (2e Note). - Cahier Office de la Recherche Scientifique et Technique Outre-mer, série
Hydrobiologie 10: 19-32.

Dejoux, C., 1976b. Synécologie des chironomides du lac Tchad (Diptères - Nématocères). - Travaux et Documents de l'Office de la Recherche Scientifique et Technique Outre-mer 56: 1-161.

Dejoux, C., 1977. Chironomides du Lac de Bam (HauteVolta). - Cahier Office de la Recherche Scientifique et Technique Outre-mer, série Hydrobiologie 11: 291-295.

Dejoux, C., 1984. Contribution à la connaissance des Chironomides de l'Afrique de l'Ouest (Diptères-Nématocères) 3e note. - Revue d'Hydrobiologie Tropicale 17: 65-76.

Ekrem, T., 1999. Six new Tanytarsus species from Ghana, West Africa (Insecta, Diptera, Chironomidae). - Spixiana 22: 53-68.

Ekrem, T. \& A. D. Harrison, 1999. Tanytarsus minutipalpus spec. nov. from the saline lakes in the Rift Valley, East Africa (Insecta, Diptera, Chironomidae). - Spixiana 22: 199-208.

Ekrem, T., F. Reiss \& P. H. Langton, 1999. Tanytarsus mancospinosus sp. n. (Diptera: Chironomidae) from eutrophic lakes in Europe. - Norwegian Journal of Entomology 46: 79-87.

Freeman, P., 1954. Chironomidae (Diptera) from Western Cape Province. IV. - Proceedings of the Royal entomological Society of London (B) 23: 172-180.

Freeman, P., 1955. A study of the Chironomidae (Diptera) of Africa south of the Sahara. Part I. - Bulletin of the British Museum (Natural History). Entomology 4: 1-67.

Freeman, P., 1956. A study of the Chironomidae (Diptera) of Africa south of the Sahara. Part II. - Bulletin of the British Museum (Natural History). Entomology 4: 285-366.

Freeman, P., 1957a. Exploration hydrobiologique des lacs Kivu, Edouard et Albert (1952 bis 1954). Chironomidae (Diptera, Nematocera), Imagines. - Institut royal des Sciences naturelles de Belgique 3: 207-221.

Freeman, P., 1957b. A study of the Chironomidae (Diptera) of Africa south of the Sahara. Part III. - Bulletin of the British Museum (Natural History). Entomology 5: 321426.

Freeman, P., 1958. A study of the Chironomidae (Diptera) of Africa south of the Sahara. Part IV. - Bulletin of the British Museum (Natural History). Entomology 7: 331352.

Freeman, P. \& P. S. Cranston, 1980. II. Family Chironomidae. - In Crosskey, R. W. (ed.) Catalogue of the Diptera of the Afrotropical Region. - British Museum (Natural History) 175-202, pls.

Glover, B., 1973. The Tanytarsini (Diptera: Chironomidae) of Australia. - Australian Journal of Zoology, Supplement 23: 403-478.

Goetghebuer, M., 1934. Zur Erforschung des Persischen Golfes. - Arbeiten über morphologische und taxonomische Entomologie aus Berlin-Dahlem 1: 36-39.

Goetghebuer, M., 1936. Chironomides du Congo Belge. Revue de zoologie et de botanique Africaines 28: 453492.

Hall, J. B. \& M. D. Swaine, 1981. Distribution and ecology of vascular plants in a tropical rain forest. - Forest vegetation in Ghana. - The Hague, 383 pp.

Hare, L. \& J. C. H. Carter, 1984. Diel and seasonal physiochemical fluctuations in a small natural West African lake. - Freshwater biology 14: 597-610.

Hare, L. \& J. C. H. Carter, 1987. Chironomidae (Diptera, Insecta) from the environs of a natural West African lake. - Entomologica scandinavica Supplement 29: 65-74. 
Harrison, A. D., 1987. Chironomidae of five central Ethiopian Rift Valley lakes. - Entomologica scandinavica Supplement 29: 39-43.

Harrison, A. D., 1997. The non-biting midges (Chironomidae) of South Africa. - url: http://www.ru.ac.za/academic/departments/zooento/Martin/insects.html

Hashimoto, H., T. Wongsiri, N. Wongsiri, T. Chalermwong, A. Lewvanich \& K. Yasumatsu, 1981. Chironomidae from rice fields of Thailand with descritiptions of 7 new species. - Technical Bulletin. Entomology and Zoology Division, Department of Agriculture, Bankok, Thailand $7: 1-47$.

Hofmann, W., 1971. Zur Taxonomie und Palökologie subfossiler Chironomiden (Dipt.) in Seesedimenten. Ergebnisse der Limnologie 6: 1-50.

ICZN, 1999. International code of zoological nomenclature. $4^{\text {th }}$ edition. - The international Trust for Zoological Nomenclature, London, $306 \mathrm{pp}$.

Kibret, T. \& A. D. Harrison, 1989. The benthic and weedbed faunas of Lake Awasha (Rift Valley, Ethiopia). - Hydrobiologia 174: 1-15.

Kieffer, J. J., 1911. Descriptions de nouveaux Chironomides de l'Indian Museum de Calcutta. - Records of the Indian Museum 6: 113-177.

Kieffer, J. J., 1912. H. Sauter's Formosa - Ausbeute. - Supplementa Entomologica 1: 32- 43.

Kieffer, J. J., 1913. Chironomide et Cecidomyidae. - Voyage de Ch. Allaud et R. Jeanell en Afrique Orientale (1911-1912). - Résultes scientifiques Insectes Diptères, Paris, 1-43 pp.

Kieffer, J. J., 1918. Chironimides d'Afrique et d'Asie conservés au Musée National Hongrois de Budapest. - Annales historico-naturales Musei nationalis Hungarici 16: 31-139.

Kieffer, J. J., 1921. Chironomides des Philippines et de Formose. - Philippine Journal of Science 18: 557-593.

Kieffer, J. J., 1923a. Étude sur les Chironomides de Formose. - Annles de la Société Linnéenne de Lyon 69: 27-41.

Kieffer, J. J., 1923b. Chironomides de l'Afrique Équatoriale. III $^{\mathrm{e}}$ partie. - Annales de la Société entomologique de France 92: 149-204.

Kikuchi, M. \& M. Sasa, 1990. Studies on the chironomid midges (Diptera, Chironomidae) of the lake Toba area, Sumatra. - Japanese Journal of Sanitary Zoology 41: 229329.

Kyerematen, R. \& O. A. Sæther, 2000. Revision of Afrotropical Rheotanytarsus Thienemann et Bause, 1913 (Diptera: Chironomidae). - Tijdschrift voor Entomologie 143: 27-70.

Kyerematen, R. A. K., T. Andersen \& O. A. Sæther, 2000. A review of Oriental Rheotanytarsus Thienemann et Bause (Diptera: Chironomidae). - Spixiana 23: 225-258.

Langton, P. H., 1991. A key to pupal exuviae of West Palearctic Chironomidae. - Cambridgeshire, Huntingdon, 386 pp.

Langton, P. H., 1994. If not 'filaments' then what? - Chironomus 6: 9.

Laville, H. \& J. N. Tourenq, 1968. Nouvelles Récoltes de Chironomides en Camargue et dans les Marismas du Guadalquivir. - Annales de Limnologie 4: 73-80.

Laville, H. \& F. Reiss, 1992. The chironomid fauna of the mediterranean region reviewed. - Netherlands Journal of Aquatic Ecology 26: 239-245.
Lehmann, J., 1979. Chironomidae (Diptera) aus Fließgewässern Zentralafrikas (Systematik, Ókologie, Verbreitung und Produktionsbiologie), Teil I. Kivu-Gebiet, Ostzaire. - Spixiana Supplement 3: 1-144.

Lehmann, J., 1981. Chironomidae (Diptera) aus Fließgewässern Zentralafrikas Teil II: Die Region um Kisangani, Zentralzaire. - Spixiana Supplement 5: 1-85.

Mazumdar, A., P. K. Chaudhuri \& N. Hazra, 1998. Additions to Tanytarsus species from mangrove ecosystems of West Bengal, India (Diptera: Chironomidae). - Oriental Insects 32: 219-238.

Petr, T., 1972. Benthic fauna of a tropical man-made lake (Volta lake, Ghana 1965-1968). - Archiv für Hydrobiologie 70: 484-533.

Pinder, L. C. V., 1982. Virgatanytarsus new genus - for the 'triangularis' group of the genus Tanytarsus van der Wulp (Diptera: Chironomidae). - Spixiana 5: 31-34

Pinder, L. C. V. \& F. Reiss, 1986. The pupae of Chironominae (Diptera: Chironomidae) of the Holarctic region Keys and diagnoses. - In Wiederholm, T. (ed.) Chironomidae of the Holarctic region. Keys and diagnoses. Part 2 - pupae. - Entomologica scandinavica Supplement 28: 299-456.

Reiss, F., 1971. Tanytarsini- Arten (Chironomidae, Diptera) aus Nepal, mit der Neubeschreibung von fünf Micropsectra- und drei Tanytarsus- Arten. - Khumbu Himal 4: 131-151.

Reiss, F. \& E. J. Fittkau, 1971. Taxonomie und Ökologie europäisch verbreiteter Tanytarsus-Arten (Chironomidae, Diptera). - Archiv für Hydrobiologie Supplement 40: 75-200.

Sæther, O. A., 1969. Some Nearctic Podonominae, Diamesinae and Orthocladinae (Diptera: Chironomidae). Bulletin of the Fisheries Research Board of Canada 170 $1-154$.

Sæther, O. A., 1980. Glossary of chironomid morphology terminology (Diptera: Chironomidae). - Entomologica scandinavica Supplement 14: 1-51.

Sæther, O. A., 1990. A review of the genus Limnophyes Eaton from the Holarctic and Afrotropical regions (Diptera: Chironomidae, Orthocladinae). - Entomologica scandinavica Supplement 35: 139 pp.

Schlee, D., 1966. Präparation und Ermittlung von Meßwerten an Chironomidae (Diptera). - Gewässer und Abwässer 41/42: 169-193.

Singh, S. \& A. K. Kulshrestha, 1975. Three new species of Tanytarsus (Diptera: Chironomidae). Oriental Insects 9: 419-424.

Stur, E. \& T. Ekrem, 2000. Tanytarsus usambarae spec. nov. from West Usambara Mts., Tanzania, East Africa (Insecta, Diptera, Chironomidae). - Spixiana 23: 219-223.

Verschuren, D., 1997. Taxonomy and ecology of subfossil Chironomidae (Insecta, Diptera) from Rift Valley lakes in central Kenya. - Archiv für Hydrobiologie Supplement 107: 467-512.

Wang, X. \& L. Zheng, 1992. Checklist of Chironomidae records from China. - Netherlands Journal of Aquatic Ecology 26: 247-255.

Wulp, F. M. van der, 1874. Dipterologische aanteekeningen. - Tijdschrift voor Entomologie 17: 109-148.

Received: 18 September 2000

Accepted: 4 December 2000 

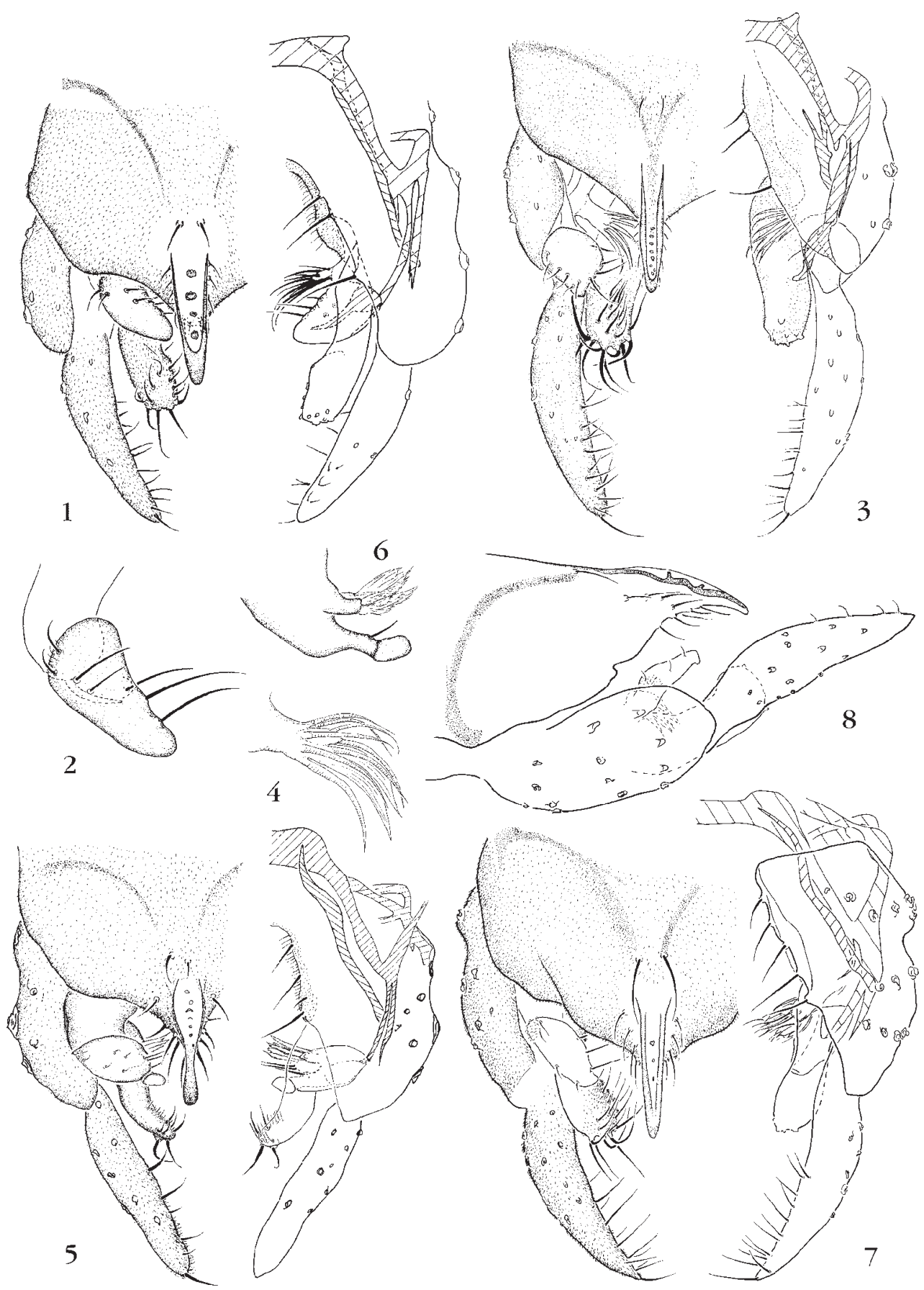

Figs. 1-8. Male imagines. - Tanytarsus ankasaensis sp. n.: 1, hypopygium; 2, superior volsella. - T. aterrimus: 3, hypopygium; 4, median volsella. - T. congus: 5 , hypopygium; 6 , digitus and median volsella. - T. elisabethae sp. n.: 7, hypopygium; 8 , hypopygium lateral view. 


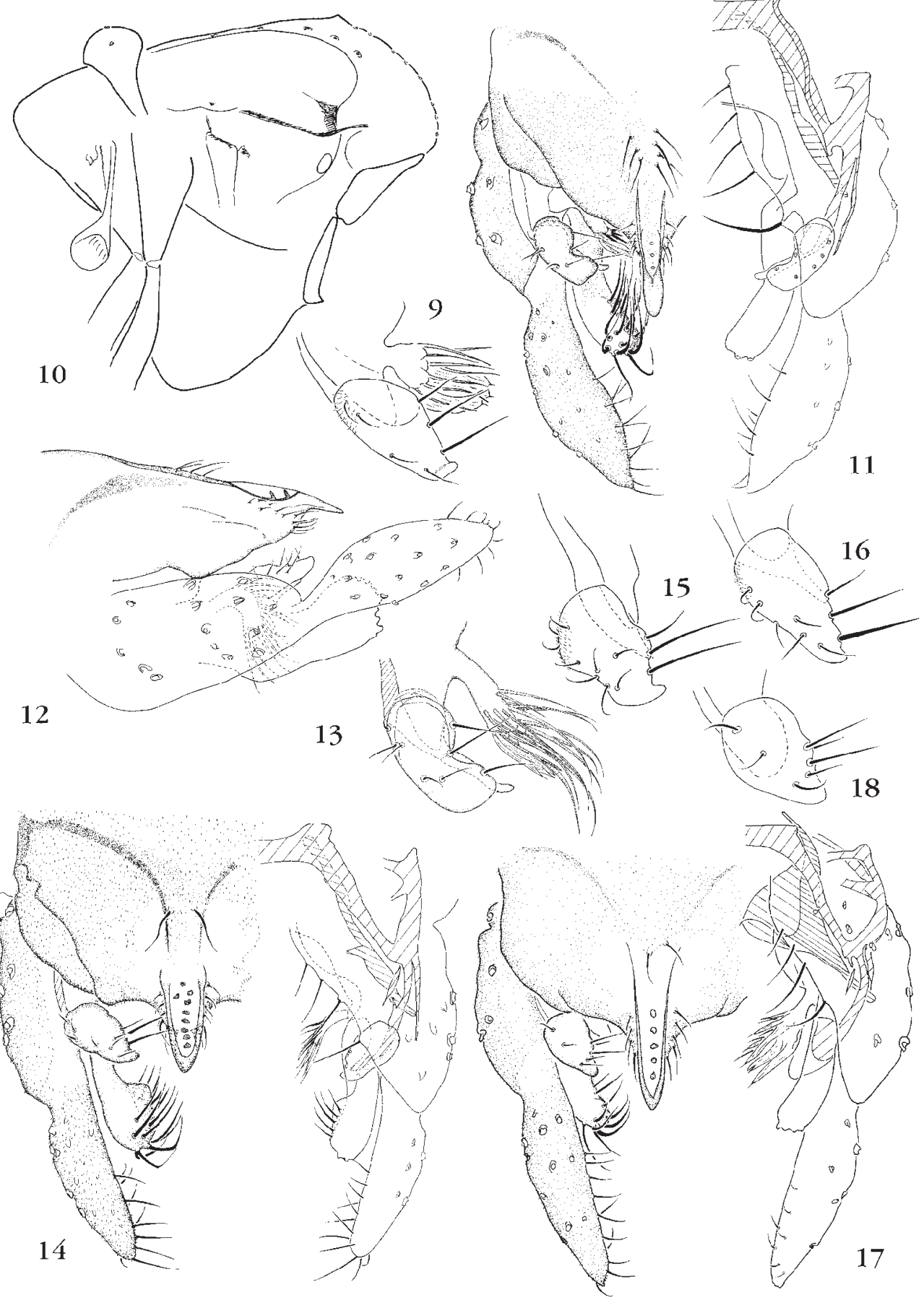

Figs. 9-18. Male imagines. - Tanytarsus elisabethae sp. n.: 9, superior and median volsellae; 10, thorax. - T. flexistilus: 11, hypopygium; 12, hypopygium lateral view; 13, superior and median volsellae. - T. formosanus: 14, hypopygium; 15,16 , variation on superior volsella. $-T$. harei sp. n.:17, hypopygium; 18, superior volsella. 


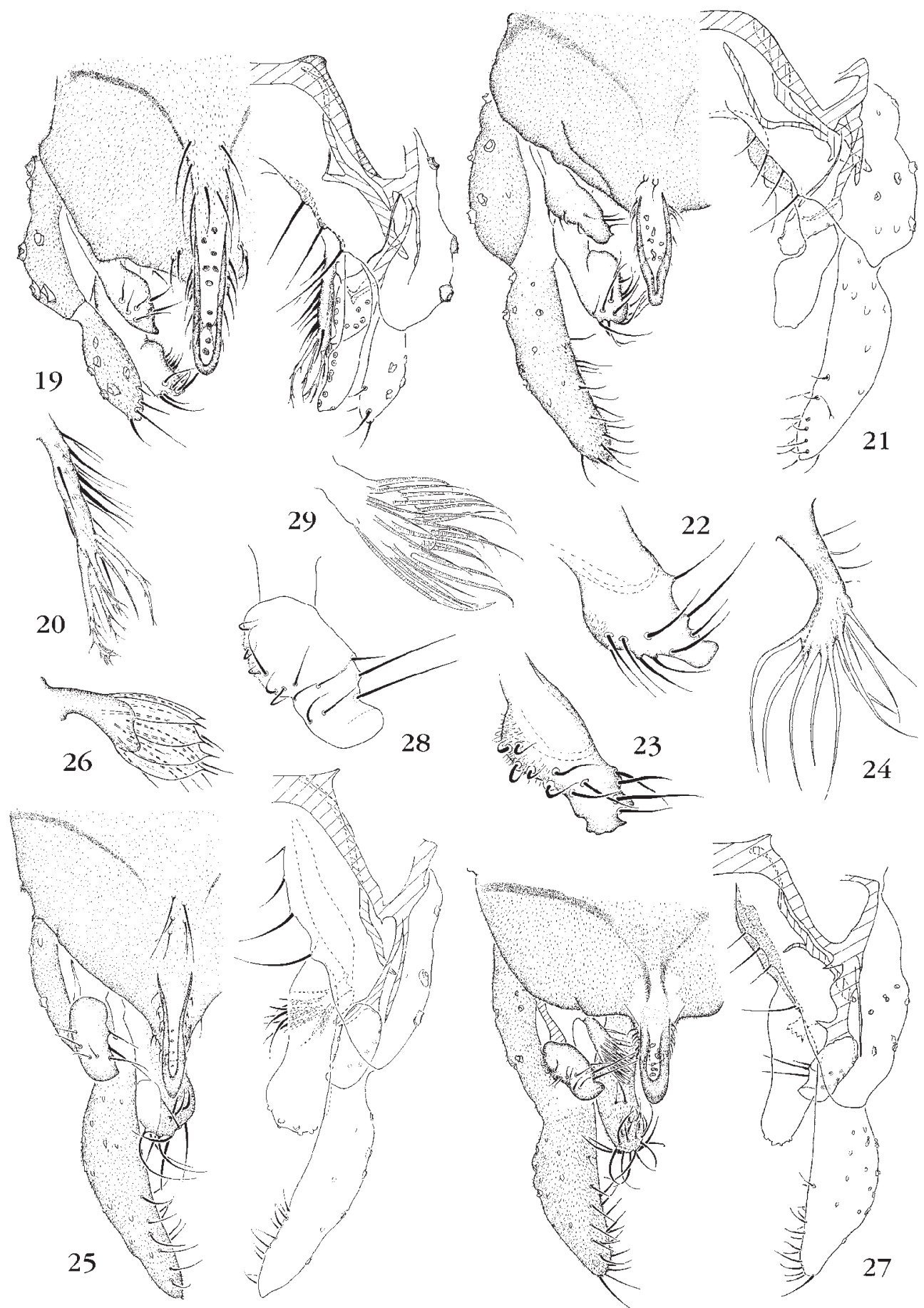

Figs. 19-29. Male imagines. - Tanytarsus kakumensis (modified from Ekrem 1999): 19, hypopygium; 20, median volsella. T. luctuosus: 21, hypopygium; 22, 23, variation on superior volsella; 24, median volsella. - T. mcmillani: 25, hypopygium; 26, median volsella. - T. minutipalpus (modified from Ekrem \& Harrison 1999): 27, hypopygium; 28, superior volsella; 29, median volsella. 


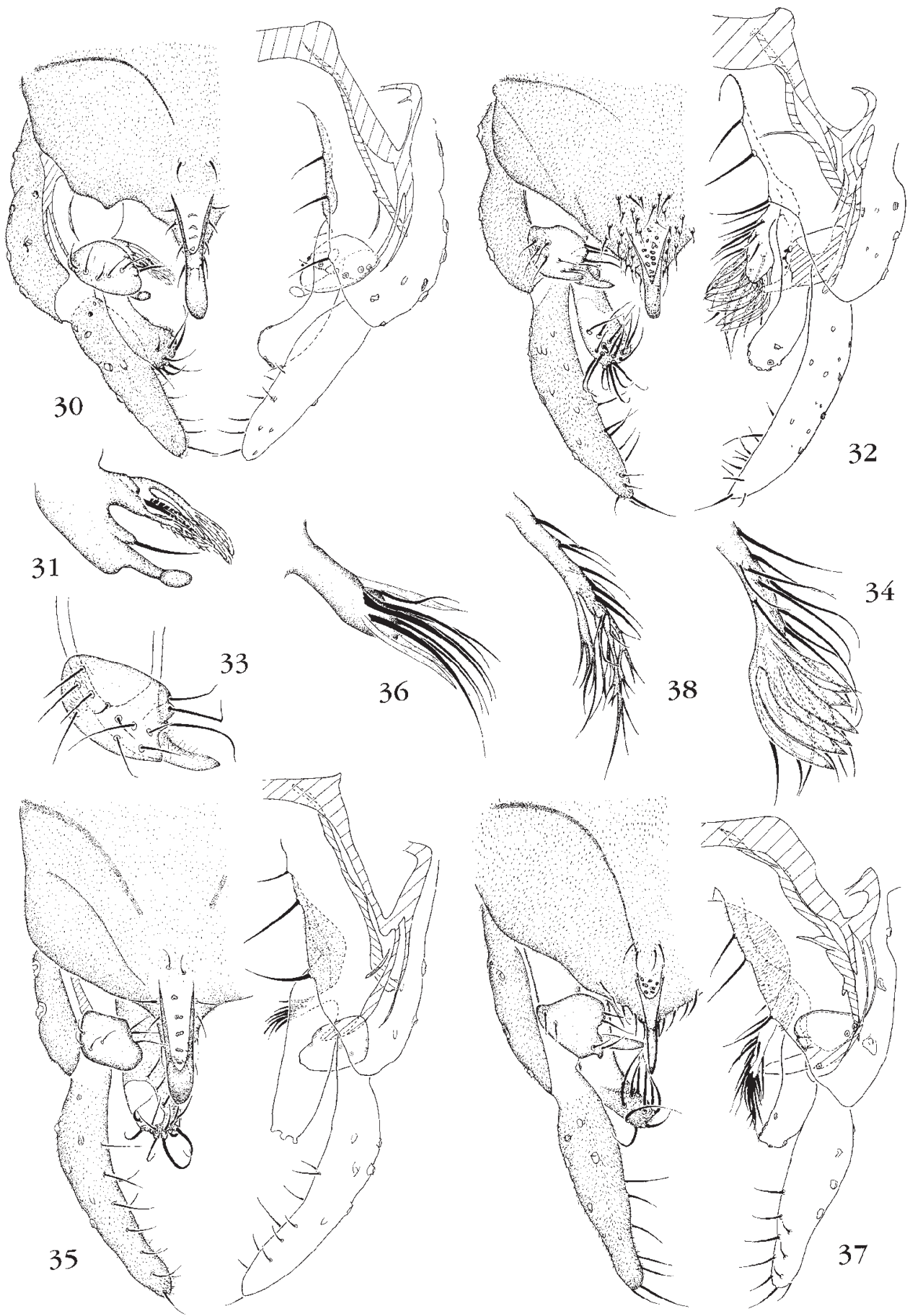

Figs. 30-38. Male imagines. - Tanytarsus pseudocongus (modified from Ekrem 1999): 30, hypopygium; 31, digitus and median volsella. - T. saetheri (modified from Ekrem 1999): 32, hypopygium; 33, superior volsella and digitus; 34, median volsella. - T. spadiceonotatus: 35, hypopygium; 36, median volsella. - T. spiesi (modified from Ekrem 1999): 37, hypopygium; 38, median volsella. 


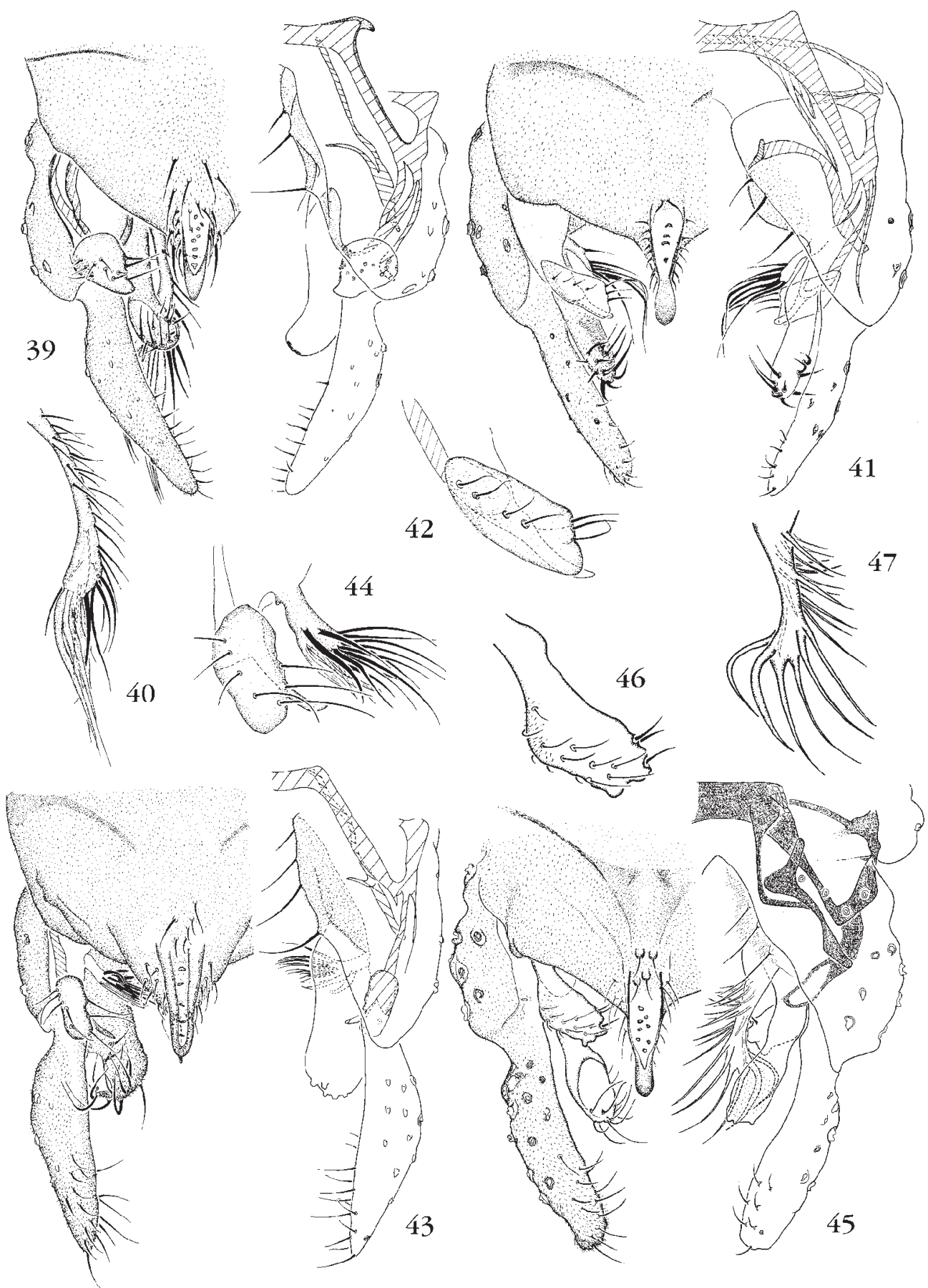

Figs. 39-47. Male imagines. - Tanytarsus superpenicillatus (modified from Ekrem 1999): 39, hypopygium; 40, median volsella. - T. tossai (modified from Ekrem 1999): 41, hypopygium; 42, superior volsella and digitus. - T. zariae: 43, hypopygium; 44, superior volsella, digitus and median volsella. - T. usambarae (modified from Stur \& Ekrem 2000): 45, hypopygium; 46, superior volsella; 47 , median volsella. 

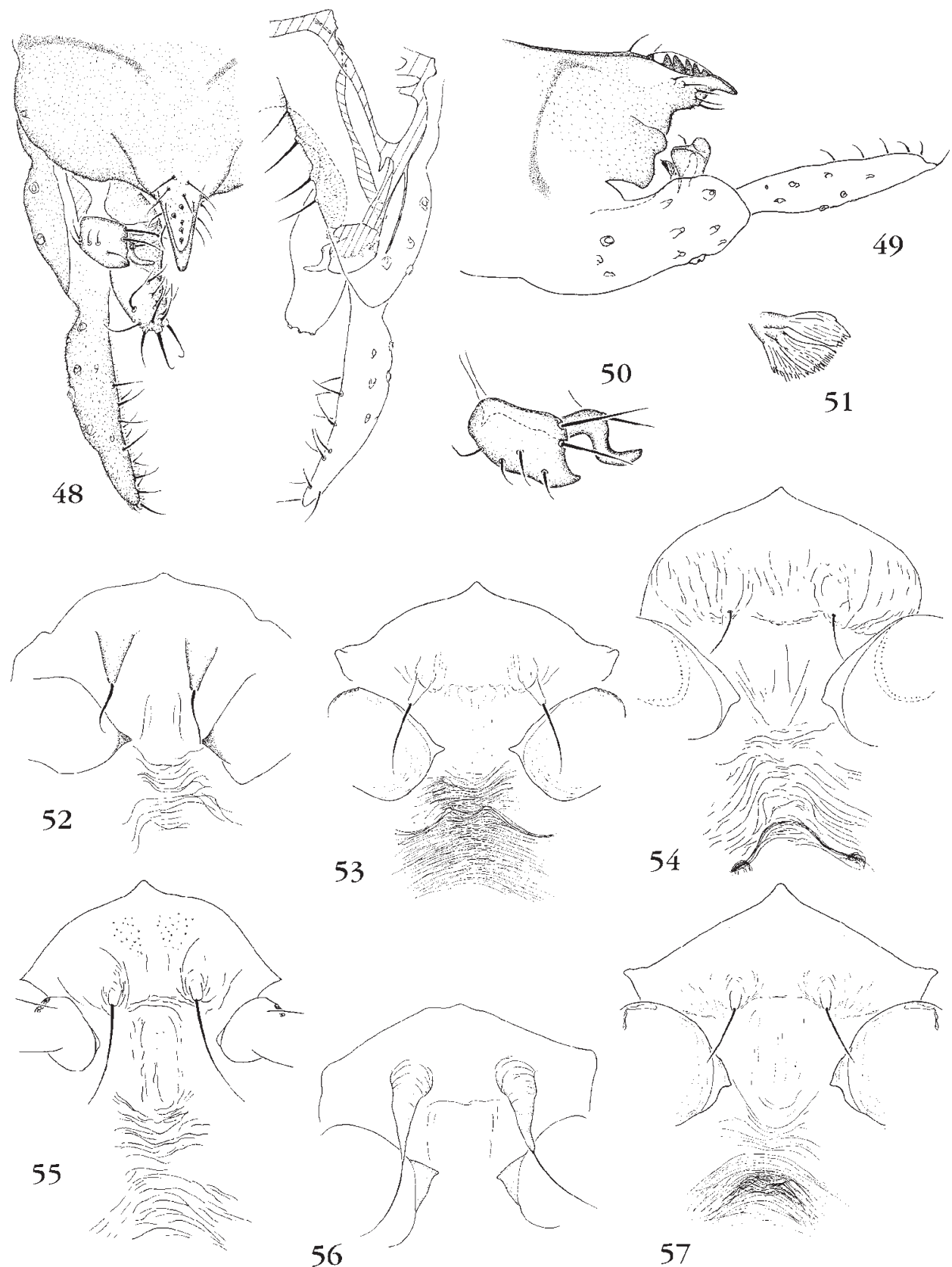

Figs. 48-51. Male imagine. - Tanytarsus trifidus: 48, hypopygium; 49, hypopygium lateral view; 50, superior volsella and digitus; 51, median volsella. - Figs. 52-57. Pupal frontal apotomes. - 52, T. formosanus; 53, T. elisabethae; 54, T. flexistilus; 55, T. trifidus; 56, T. minutipalpus ; 57, T. spadiceonotatus. 

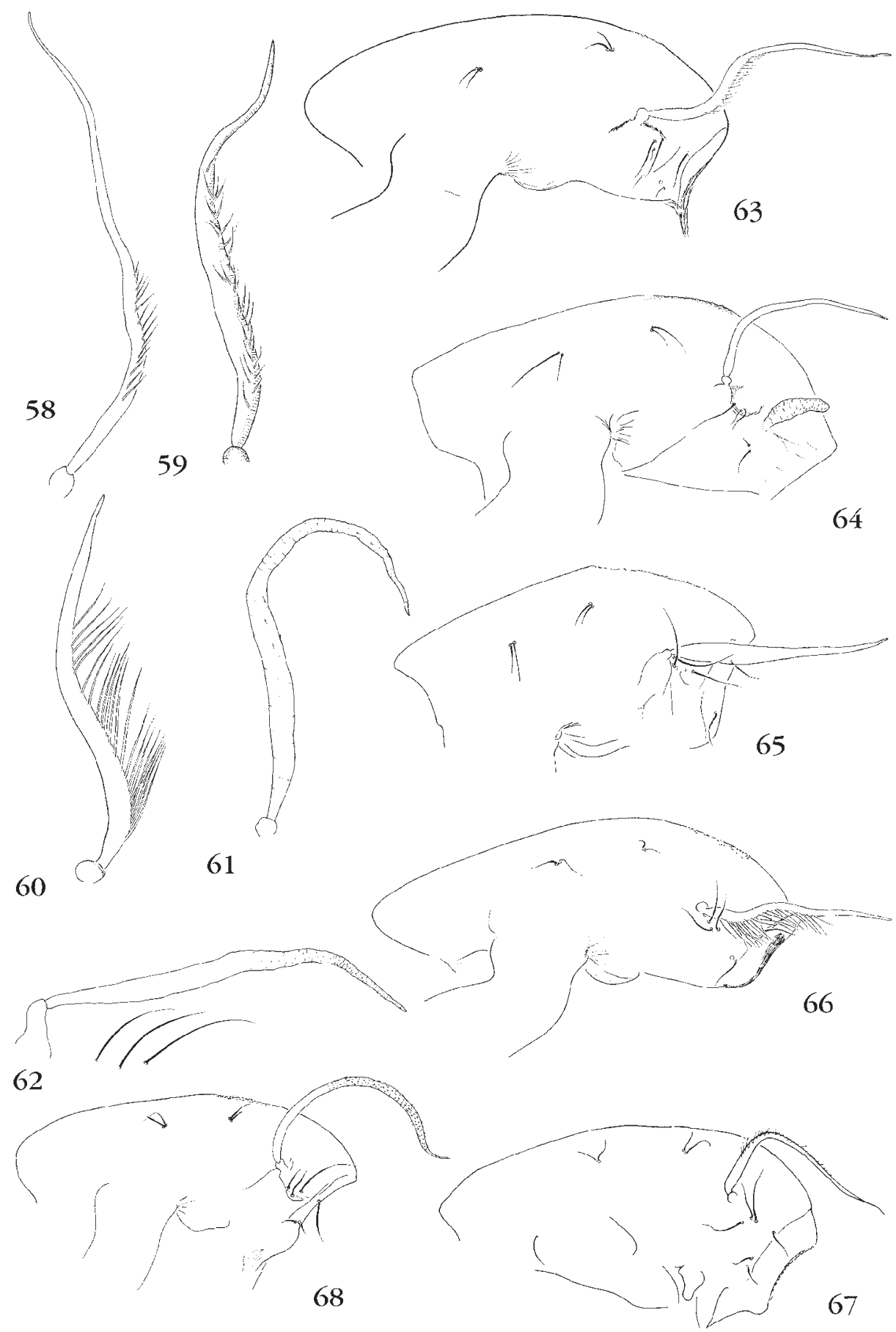

Figs. 58-68. Pupal cephalothoraces and thoracic horns. - 58, 63, Tanytarsus elisabethae; 59, 67, T. formosanus; 60, 66, T. spadiceonotatus; 61, 64, T. flexistilus; 62, T. minutipalpus (modified from Ekrem \& Harrison 1999); 65, T. luctuosus; 68, T. trifidus. 

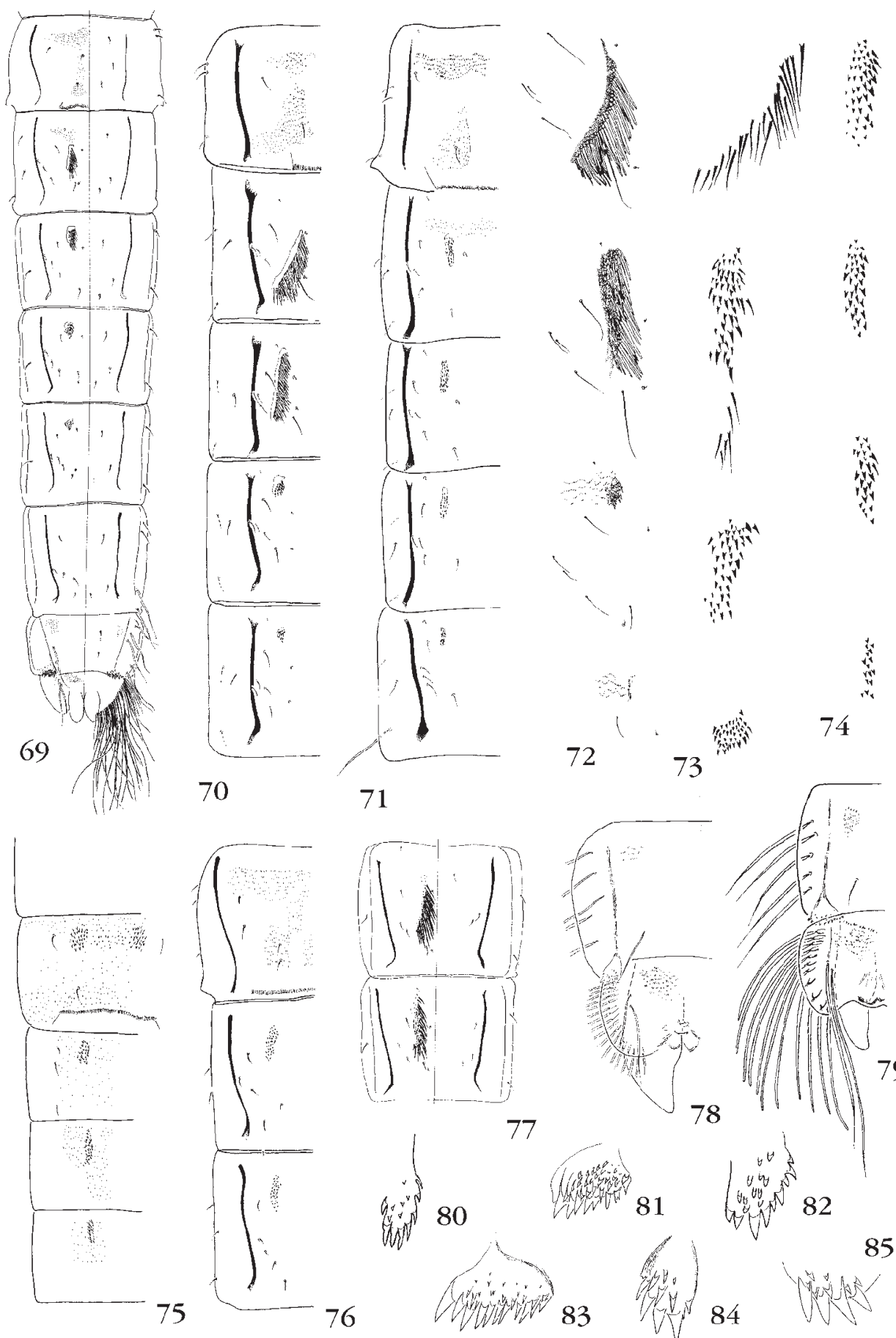

74
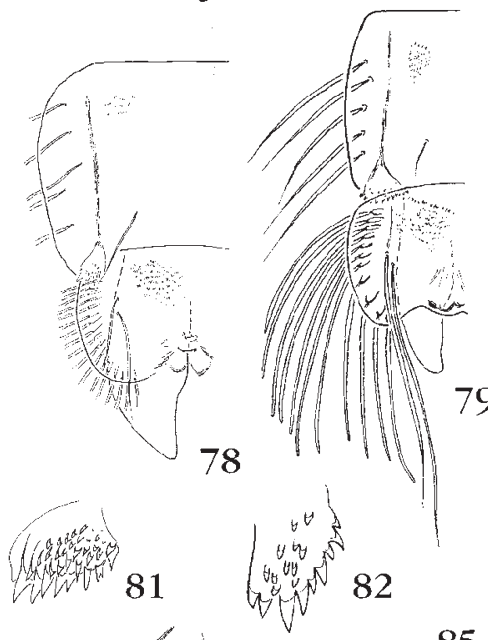

85

Figs. 69-85. Pupal armament, anal lobes and posterolateral combs. - 69, 77, T. formosanus; 70, 79, 83, T. spadiceonotatus; 71, 78, 84, Tanytarsus elisabethae; 72, 81, T. flexistilus; 73, 82, T. minutipalpus (modified from Ekrem \& Harrison 1999); 74, 76, 80, T. trifidus; 75, 85, T. luctuosus. 

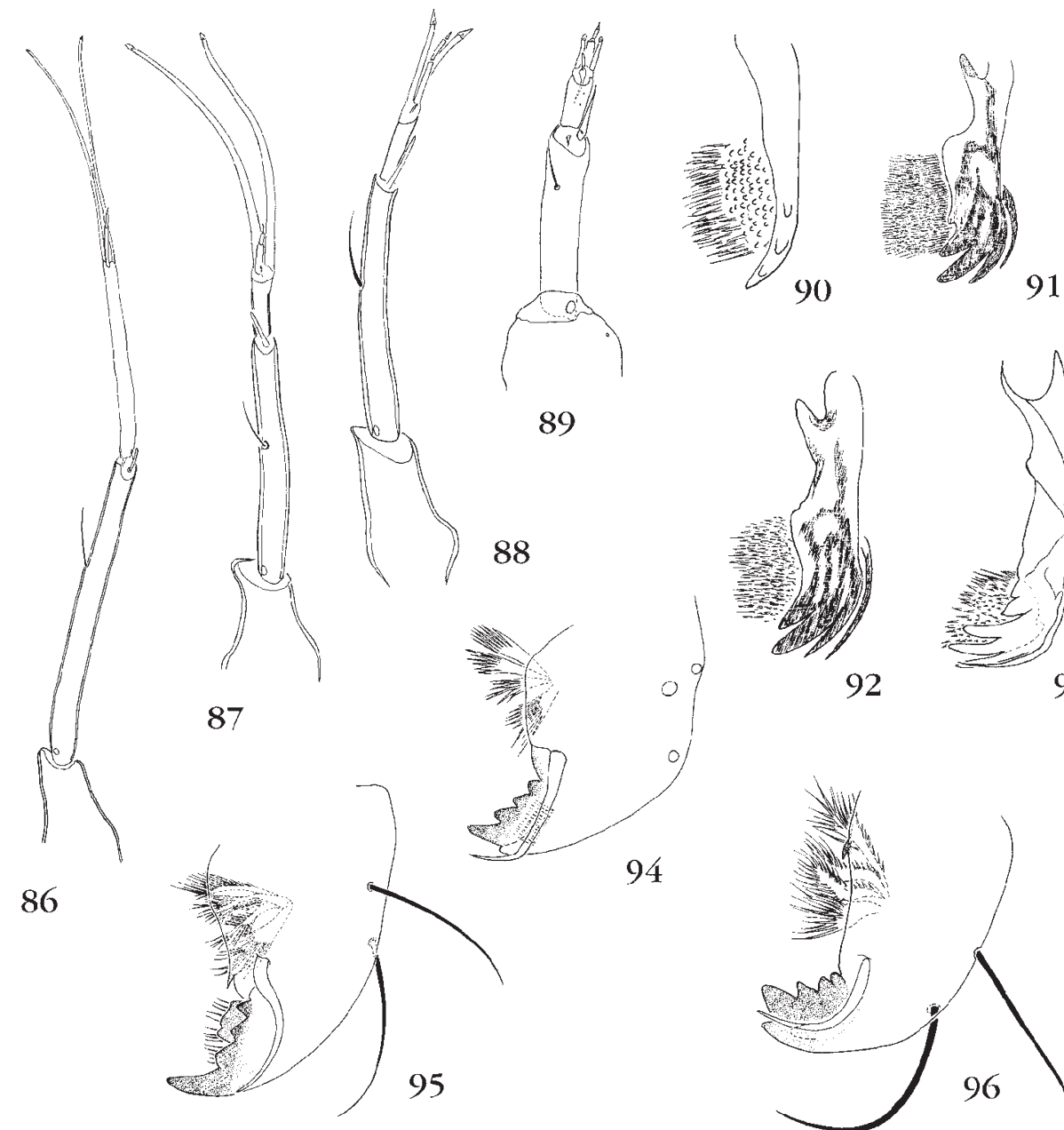

92
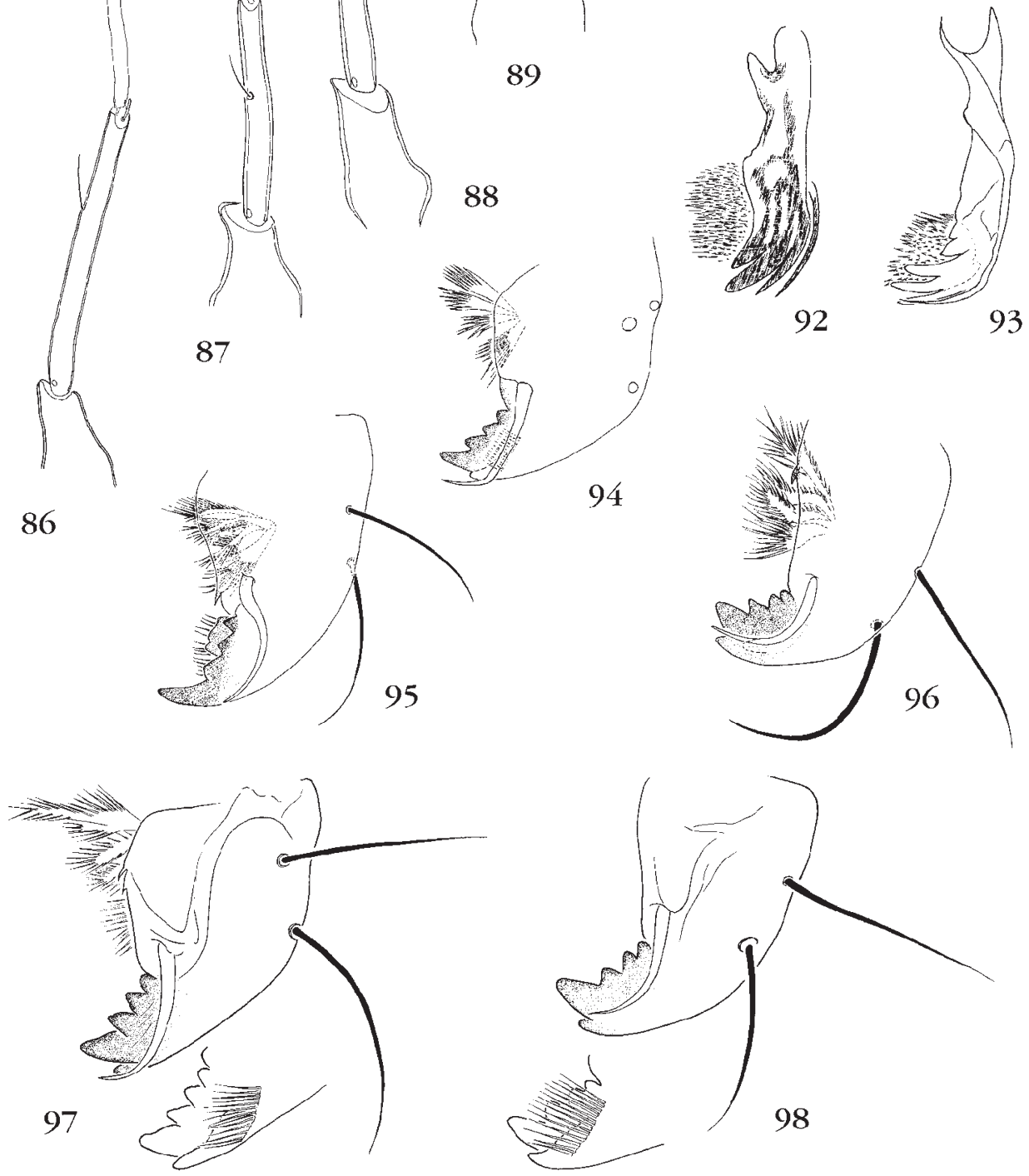

Figs. 86-98. Larval antennae, mandibles and premandibles. - 86, 90, 91, 96, T. flexistilus; 87, 92, 97, T. spadiceonotatus; 88, 98, Tanytarsus elisabethae; 89, 93, 95, T. minutipalpus (modified from Ekrem \& Harrison 1999); 94, T. trifidus. 

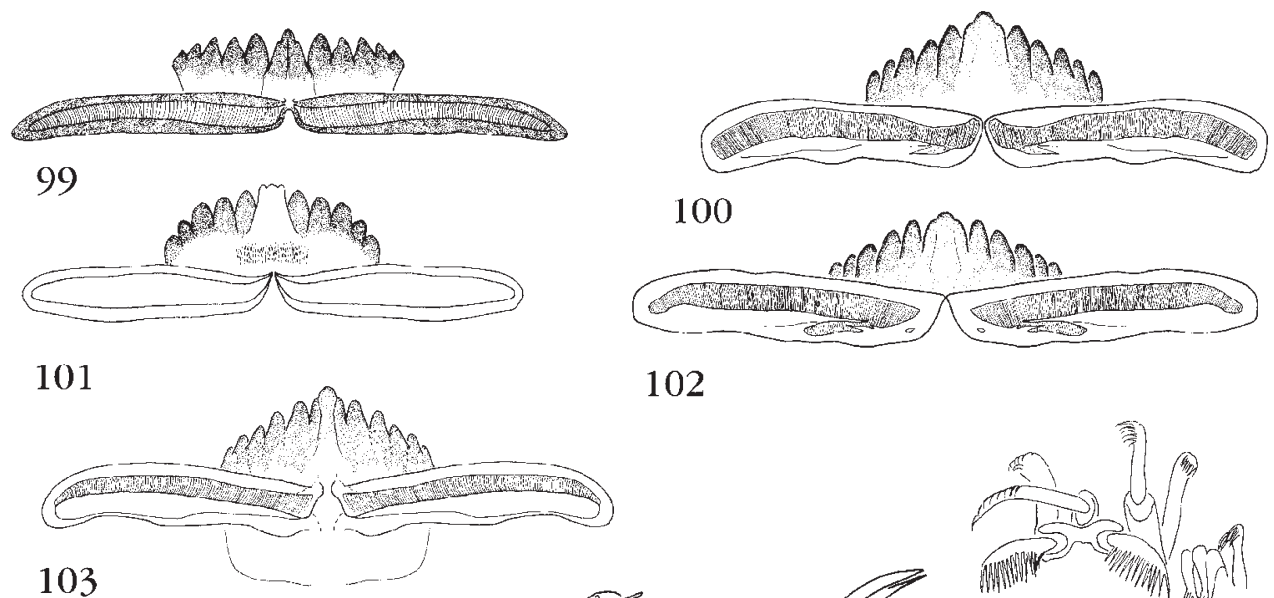

102
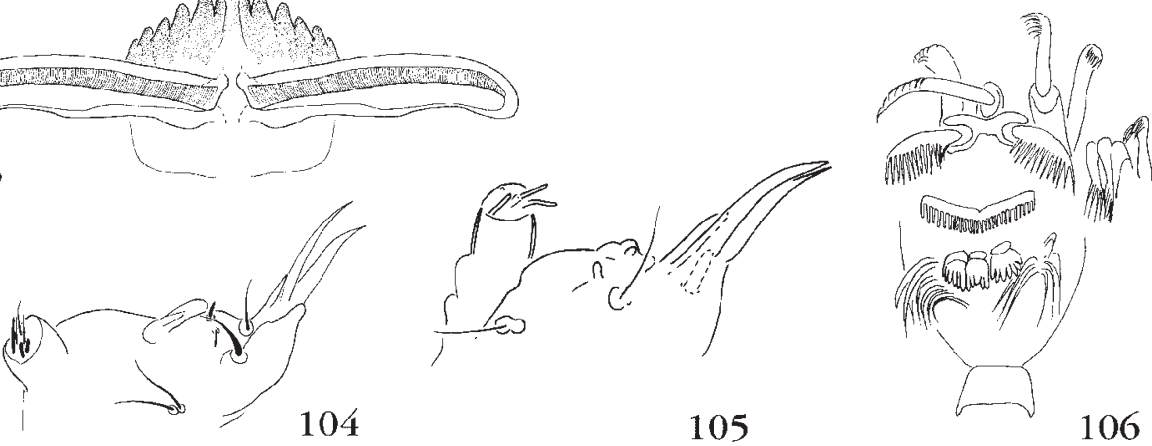

Figs. 99-106. Larval menta, maxillae and labrum. - 99, T. minutipalpus (modified from Ekrem \& Harrison 1999); 100, 105, Tanytarsus elisabethae; 101, T. trifidus; 102, T. spadiceonotatus; 103, 104, 106, T. flexistilus. 